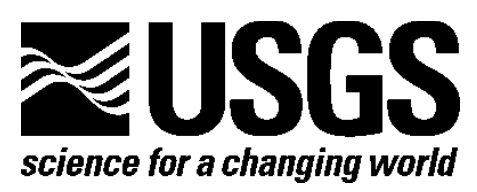

Fort Collins Science Center

\title{
Evaluation of the National Gap Analysis Program (GAP): A Survey of Users of GAP Data-Report to Respondents
}

By Joan M. Ratz

Open-File Report 2014-1166 


\section{U.S. Department of the Interior \\ SALLY JEWELL, Secretary}

\section{U.S. Geological Survey \\ Suzette M. Kimball, Acting Director}

U.S. Geological Survey, Reston, Virginia: 2014

For more information on the USGS-the Federal source for science about the Earth,

its natural and living resources, natural hazards, and the environment-visit

http://www.usgs.gov or call 1-888-ASK-USGS

For an overview of USGS information products, including maps, imagery, and publications, visit $h$ ttp://www.usgs.gov/pubprod

To order this and other USGS information products, visit http://store.usgs.gov

Suggested citation:

Ratz, J.M., 2014, Evaluation of the National Gap Analysis Program (GAP)—A survey of users of GAP data-Report to respondents: U.S. Geological Survey Open-File Report 2014-1166, 94 p., http://dx.doi.org/10.3133/ofr20141166.

ISSN 2331-1258 (online)

Any use of trade, product, or firm names is for descriptive purposes only and does not imply endorsement by the U.S. Government.

Although this information product, for the most part, is in the public domain, it also may contain copyrighted materials as noted in the text. Permission to reproduce copyrighted items must be secured from the copyright owner. 


\section{Contents}

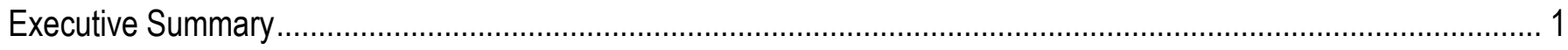

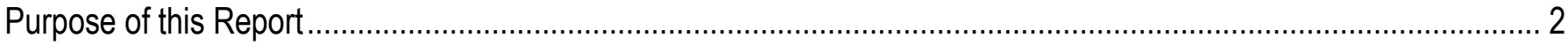

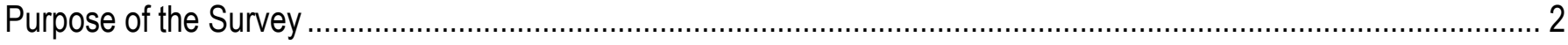

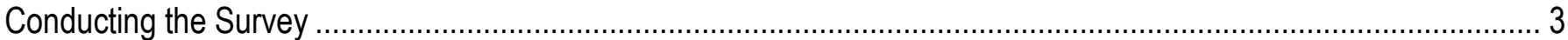

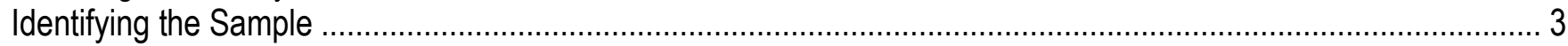

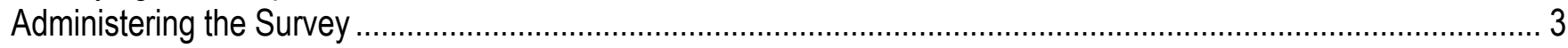

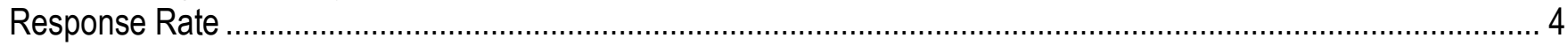

Preliminary Findings

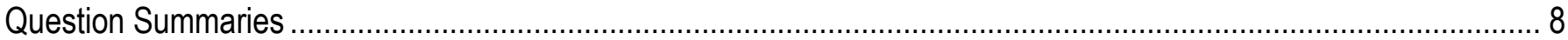

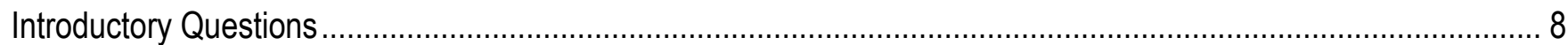

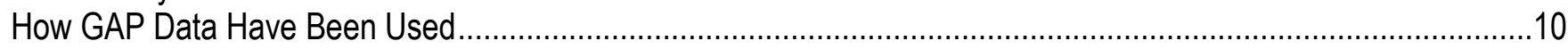

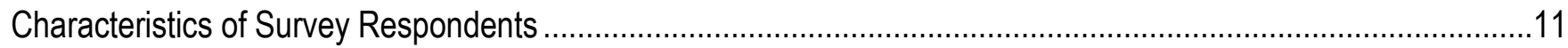

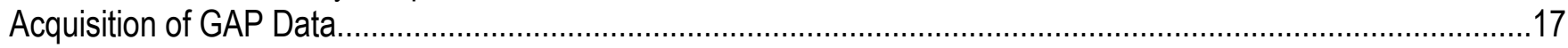

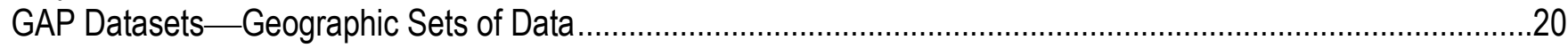

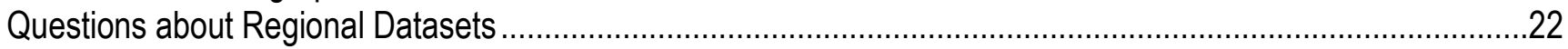

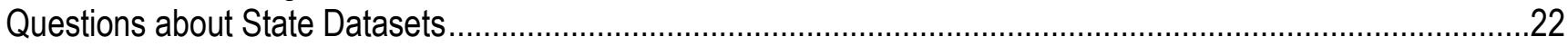

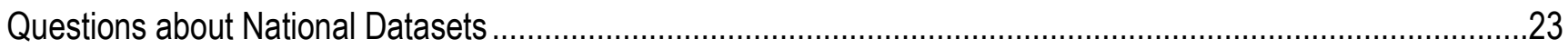

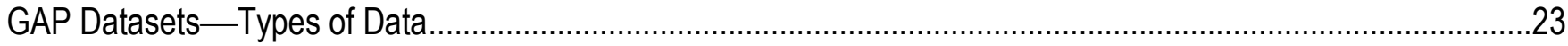

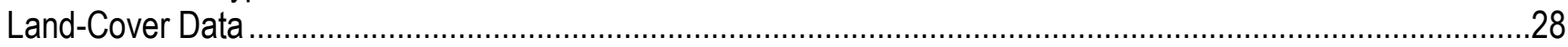

Predicted Species Distribution Data ......................................................................................................

Stewardship/Protected Areas Data ......................................................................................................4

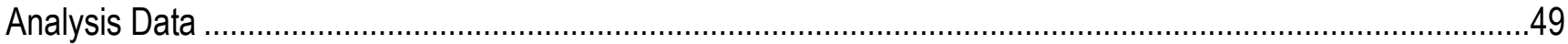

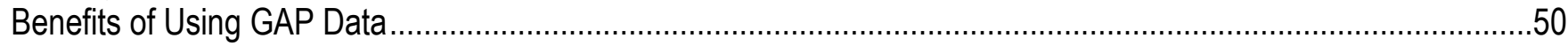

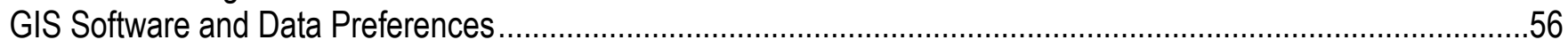

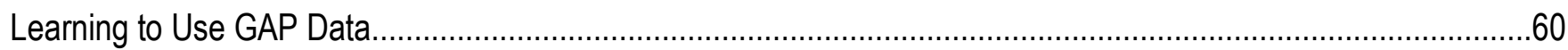

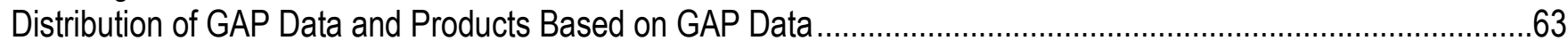

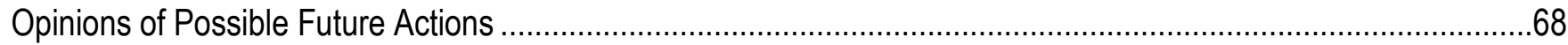

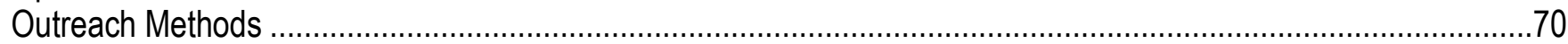

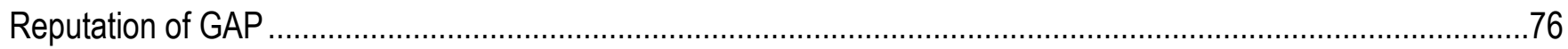

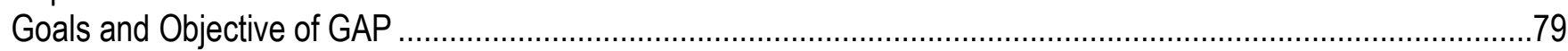

General Comment.

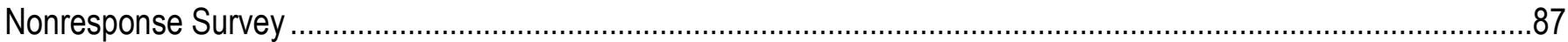

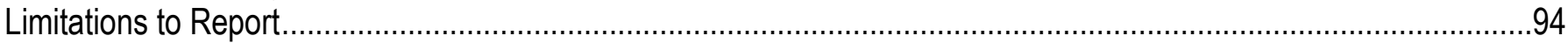

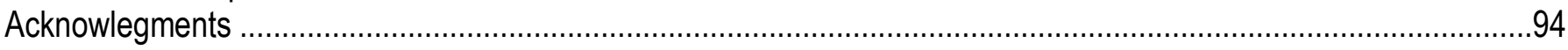

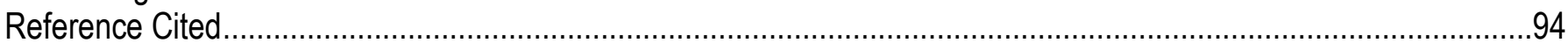




\section{Evaluation of the National Gap Analysis Program (GAP): A Survey of Users of GAP Data-Report to Respondents}

By Joan M. Ratz

\section{Executive Summary}

This report provides a summary of responses to the questions included in a survey of individuals who use or have used data created and provided by the U.S. Geological Survey (USGS) National Gap Analysis Program (GAP). The survey was commissioned by the GAP main office and was conducted by USGS personnel in the Policy Analysis and Science Assistance (PASA) branch. The data collection process started on September 18, 2012, and ended on November 9, 2012. The dataset includes the responses from 359 individuals. The adjusted response rate for the survey was 35 percent. This report provides a summary of results for the survey questions in the order in which the questions were asked. The text of comments provided by respondents to open-ended questions is provided.

Because the response rate was lower than 80 percent, the Office of Management and Budget (OMB) required a nonresponse survey of those who did not respond to the first survey. The nonresponse survey was very brief and included primarily demographic questions. All individuals who were sent the original survey and who did not respond or declined to respond to that survey were sent the nonresponse survey. The nonresponse survey was conducted from January 11, 2013, to January 24, 2013. The responses to the questions on the nonresponse survey are included in this report.

The preliminary conclusions are based only on frequencies and averages of responses to the survey questions. Most respondents to the survey are currently using or have used GAP data within the last 5 years. When asked which geographic set of data they were familiar with, the most frequent response was state data. When asked which type of GAP data they were familiar with, respondents most frequently indicated that they were most familiar with land-cover data.

The respondents were asked only questions that pertained to the type of data with which they were most familiar. The respondents who answered questions about land-cover data were generally positive in their opinions. The respondents indicated that the land-cover data should be updated every 5 to 7 years. They rated land-cover data as medium quality and indicated that the data met most of the users' expectations. Respondents indicated that there are alternative data sources to GAP land-cover data.

The respondents who answered questions about predicted species distribution data were generally positive in their opinions. They rated predicted species distribution data as medium quality and indicated that the data met most of the users' expectations. When asked how frequently the predicted species distribution data should be produced, respondents were split, choosing the intervals of 5 to 7 years and 8 to 10 years with equal frequency. Fifty-eight percent of respondents answering the predicted species questions indicated that there were no alternatives to GAP predicted species distribution data.

The respondents who answered questions about stewardship data were generally positive in their opinions of the GAP data. GAP stewardship data were viewed as being high quality and meeting most of users' expectations. Respondents indicated there are alternative sources of data to GAP stewardship data. 
The respondents who answered questions about analysis data were generally positive in their opinions of the GAP data. Respondents indicated there are alternative sources of data to GAP analysis data.

Respondents to the survey indicated they intend to continue using GAP data and will use future releases of GAP data. They indicated there were multiple benefits to using GAP data.

Several sections of the survey addressed methods by which GAP could promote the use of GAP data. When asked about training sessions on how to use GAP data, respondents indicated that such training would be only somewhat helpful and that they would not be willing to pay more than a negligible amount. Respondents indicated that it was generally unlikely that they would submit a presentation to or attend a GAP conference. Most frequently respondents indicated they have never used information from the "GAP Bulletin" and that they were not familiar with the publication. Most survey respondents had visited the GAP web site at some time. They visited the web site primarily to obtain information or download data and indicated that the web site visit met some or all of their needs.

GAP was perceived as having a generally positive reputation but one that might be limited in scope. When asked what percentage of people who could use GAP data know about GAP, respondents most frequently selected the response option "Between 26 and 50\%."

The survey ended with an open-ended question asking respondents for other comments about GAP data. Respondents were provided with an opportunity to add their email address to a mailing list for GAP.

\section{Purpose of this Report}

This is a report to survey respondents. The intent of this report is to provide those who responded to the survey with feedback regarding the responses to the survey questions. This report includes brief descriptions of the purpose of the survey and of the procedure followed to conduct the survey. The survey results in this report include the response rate to the survey and descriptive results for each survey question. The survey questions are listed in the order in which they appeared on the survey. The frequencies with which the response options were chosen by survey respondents are provided. When appropriate for the question type, the average of the responses is provided. It would be inappropriate to draw conclusions or make recommendations based upon the level of analyses included in this report.

\section{Purpose of the Survey}

GAP periodically evaluates its program performance regarding the use of its data and science. The Policy Analysis and Science Assistance (PASA) branch at the USGS Fort Collins Science Center was asked to conduct an evaluation of GAP. The aim of the evaluation included three objectives-

- to characterize users of GAP data and products;

- to identify how those products have been used; and

- to estimate GAP's contribution, whether direct or indirect, to conservation of biodiversity. The most direct method to evaluate the use of GAP data is to survey individuals who use GAP data now or have used the data in the past. 


\section{Conducting the Survey}

\section{Identifying the Sample}

Identifying the sample for this survey was time consuming and required multiple approaches. The data produced by GAP are available to the public at no cost. GAP does not require the individuals who download data to provide any identifying information nor does GAP maintain customer lists. For these reasons, the identification of GAP data users for the purposes of conducting a survey presented a challenge.

Some GAP users are known to GAP, but there are unknown users of GAP data whose perspective should be included in a thorough evaluation of GAP. Two approaches were used to identify GAP data users. A "snowball sampling" approach was used to identify GAP data users. This approach is typically used to identify research subjects from hidden populations. Because there are no existing comprehensive lists of GAP users, this population was considered a hidden population. As another part of the evaluation of GAP, a review of published literature that cited GAP data was conducted (Ratz and Conk, 2014). The authors identified as having used GAP data were added to the list of GAP users.

The snowball sampling approach was started by creating a GAP user database that included authors who published articles in volumes 1 to 14 of the "GAP Bulletin." Names of potential users were solicited from the offices that develop state and regional GAP data. The names they provided were added to the GAP user database. The lists included subscribers to the "GAP Bulletin," names from individuals participating in a study of State Wildlife Action Plans, and names of individuals who had downloaded GAP data from a site maintained by a state or a university offering state level GAP data. The database included the name and email address for each individual.

Each individual in the database was emailed a message alerting them to the upcoming survey and asking if they could provide the names and email addresses of three other individuals who they knew to be users of GAP data. When a name was received that was not already in the database, the name was added, and an email was sent to that person asking if he or she could provide the names and email addresses of three other individuals who were users of GAP data. This process was followed until the number of new names received declined sharply.

\section{Administering the Survey}

The variety of GAP products available (state, regional, or national; land cover, predicted species distributions, stewardship, or analysis), the importance of the information addressed in the survey, and the varied nature of identified GAP users were compelling reasons to send the survey to the complete list of 1,264 identified GAP users rather than sampling from the list.

A message written by Dr. Kevin Gergely, National GAP Program Manager, introducing the survey was emailed to the individuals included in the survey. Although the message was from Dr. Gergely, it was sent by PASA personnel to maintain the privacy and protect the identity of those participating in the survey. After this introductory letter was sent, Joan Ratz, USGS Volunteer Social Scientist, sent an email message that included the link to the survey. This message was sent using KeySurvey software. KeySurvey automatically sent reminders to individuals who had not completed the survey 7 and 10 days after the survey opened. The data collection process started on September 18, 2012, and ended on November 9, 2012.

The survey was conducted entirely online. The survey was adaptive so that the number of total questions asked of respondents would be limited. Specifically, the parts of the survey that addressed certain types of GAP data solicited responses only from individuals who have knowledge of those types 
of data. For example, the questions regarding land-cover data were directed only to respondents who indicated that they were most familiar with the land-cover data provided by GAP.

\section{Response Rate}

Of the 1,264 surveys initially sent, 215 were undeliverable due to invalid email addresses. Fifteen individuals requested to be removed from the survey sample. Six individuals were out of the office for the duration of the data collection process. This left a potential sample size of 1,028. Three hundred fifty-nine respondents answered the survey questions. The adjusted response rate was 35 percent.

Because the survey sample included individuals who were not Federal employees, the survey had to be submitted to the information collection request process overseen by the Office of Management and Budget (OMB). OMB requires that any survey with a response rate less than 80 percent must have a nonresponse bias survey. A nonresponse survey was conducted as part of this survey process. The results of the nonresponse survey are described in this report in a separate section "Nonresponse Survey" that follows the question summaries of the survey.

\section{Preliminary Findings}

This report includes only summaries of the responses to the questions asked on the survey. Until additional analyses are complete, only preliminary conclusions reached on the basis of these summary statistics can be presented.

Answers to the introductory questions indicate that most survey respondents use GAP data currently or have used GAP data within the last 5 years (2007-12). For those who are not now nor within the last 5 years users of GAP data, the primary reason they do not use GAP data is that it is not applicable to their current work.

Respondents who used GAP data within the last 5 years most frequently used the data to address the issues of biodiversity conservation and fish and wildlife management. They have used GAP data to provide information regarding conservation related policy issues and to provide decisionmakers with knowledge.

Survey respondents were from a variety of organizations; most users were from State and Federal agencies. Respondents indicated that conservation of biodiversity was important to their organizations. When asked to describe their current position, geographic information systems (GIS), ecology, fish and wildlife management, and conservation were the most frequently selected options. Respondents were asked to name a source they read most frequently to keep current in their field. The most frequently named publications were the "Journal of Wildlife Management" and "Conservation Biology."

The survey respondents were primarily skilled users of GIS, and most of them have been using GIS for more than 10 years. They learned GIS by themselves, through a graduate course, or through informal on the job training. They mostly use data to create information products but acquire, create, maintain, and distribute datasets. The opinion of many respondents was that only basic GIS skills are needed to use GAP data, although some respondents thought that high skill levels were needed.

Approximately one-third of respondents were partners in a state GAP project; otherwise, respondents often learned about GAP from someone else. They received GAP data either from a download from the GAP web site or through direct distribution from GAP.

Respondents were asked with which set of geographic data they were most familiar. Seventy percent of respondents were most familiar with state data, 20 percent of respondents were most familiar 
with regional data, and only 10 percent were mainly familiar with national data. Those who use state data do so because the state data meet their needs more closely than regional data, but state data are not necessarily perceived as being more accurate. Those who use regional data do so because regional data meet their needs more closely than state data, but regional data are not necessarily perceived as being more accurate or current than state data. Those who use national data do so because they need data consistent at a national scale.

Most survey respondents agreed that the data they needed for their area were available. Forty percent used data that are approximately state sized in extent.

In terms of the types of data used, 57 percent of the respondents were most familiar with GAP land-cover data. These respondents were asked questions regarding land-cover data. Respondents indicated GAP land-cover data were useful at state, regional, ecosystem, and county levels. They indicated that GAP land-cover data were necessary at state, regional, ecosystem, county, and national levels. Having consistent seamless national coverage of vegetation was very important to respondents. When asked how frequently GAP land-cover data should be produced, the most frequently selected time period was 5 to 7 years. Opinions about land-cover data were generally positive. Respondents to the land-cover questions indicated the GAP land-cover data were of medium quality and that the data met most of the users' expectations. There are alternative sources to GAP land-cover data, and survey respondents named a variety of alternatives, such as state data, National Land Cover Data (NLCD), and LANDFIRE. Respondents gave GAP a grade of "B" for performance on mapping the land cover of the United States.

About 22 percent of survey respondents indicated they were most familiar with predicted species distribution (PSD) data. These respondents were asked more specific questions about PSD data. These respondents indicated that GAP data were useful at state, regional, and ecosystem levels and that GAP data are necessary at those levels as well as at national and county levels. It is important to respondents to have consistent seamless national coverage of PSD data. When asked how frequently they thought GAP PSD data should be produced, respondents were split between the response options of " 5 to 7 years" and "8 to 10 years." Respondents agreed that it is more useful for species to be modeled on biological range rather than along state boundaries. Respondents agreed that the species modeled by GAP are appropriate for their uses. In general, respondents' opinions about GAP PSD data were favorable. Respondents to the PSD questions indicated the GAP PSD data were of medium quality and the data met most of the users' expectations. When asked if there were alternative sources to GAP PSD data, 58 percent of respondents to that question indicated there were no alternative sources. Respondents gave GAP a grade of "B" for performance on mapping PSD of vertebrate species for the United States. However, a nearly equal percentage indicated they lacked sufficient information to provide a grade.

Ten percent of respondents indicated they were most familiar with the stewardship data and were asked specific questions about that type of data. Respondents indicated GAP stewardship data were useful at the state, national, regional, and ecosystem levels, and GAP stewardship data are needed at the state, national, regional, ecosystem, and county levels. It is important to respondents to have consistent seamless national coverage of stewardship data. In the opinion of these respondents, GAP stewardship data should be updated every 2 to 4 years if not more frequently. Respondents who answered the stewardship questions were generally positive in their opinions of GAP stewardship data. However, when asked if GAP stewardship data were the best available data of that type, 41 percent were neutral, and there was no majority either in agreement or disagreement. GAP stewardship data are viewed as being high quality and meet most of the users' expectations. However, 41 percent of respondents indicated they did not have enough information to grade GAP's performance on documenting land ownership and protection in the United States. When asked if there were alternative sources for the 
information provided in GAP stewardship data, 75 percent of respondents indicated there were alternatives.

When asked to identify with which type of GAP data they were most familiar, 11 percent of respondents indicated familiarity with analysis data. These respondents were asked a few questions specific to GAP analysis data. Respondents' opinions of analysis data were generally positive. When asked if there were alternative sources to GAP analysis data, 63 percent of these respondents indicated there were alternative sources.

After answering questions specific to the types of GAP data they use, respondents were asked about benefits of the use of GAP data. Respondents generally agreed that they intend to continue to use GAP data and that GAP data are compatible with other data they use. Respondents indicated that GAP data improve their capacity to affect conservation of biodiversity and help their organization achieve conservation-related goals. Their organizations experienced time savings, efficiency in the work process, improved effectiveness, and improved decisions. If GAP data were no longer available, respondents generally agreed that the work of their organization would suffer and that they would have to search for an acceptable replacement dataset. Respondents could not indicate how much a replacement would cost because there is no readily available substitute. Respondents indicated their work products would be less effective if they had to use alternate data instead of GAP.

A section of the survey included questions about respondents' GIS software and data preferences. The most frequently used GIS software package was ArcGIS. Respondents reported that they also have access to multiple other GIS software packages such as Imagine, ArcView, and ENVI. Respondents indicated a preference for downloading data rather than accessing web-based tools. They prefer direct download options. When downloading GIS raster data, whether GAP data or other data, respondents most frequently use ESRI GRID (Interchange format).

Respondents indicated that using GAP data for the first time was neither difficult nor easy. If they had a question about using GAP data, they would most likely go to the GAP web site to find information.

When asked questions regarding training on the use of GAP data, more than one-half of the respondents indicated it would be somewhat valuable with an average of 2 on a 4-point scale. Respondents would not be willing to pay more than a negligible amount for training. If respondents were to attend training they would want it to be for only one day. Respondents believed that the most effective form of training would be in an instructor-led classroom but that the most practical form of training would be web based.

When asked about contact with GAP staff, respondents most frequently indicated that they have not had contact with staff. Respondents were asked how they learned to use GAP data. The most frequent response was that they had figured it out by themselves and that it was somewhat easy to do.

A series of questions addressed the linkages between GAP and GAP users. Most frequently, respondents indicated that they knew someone involved in developing regional or state GAP projects but that they did not know anyone currently employed by GAP.

A section of survey questions addressed how GAP data are distributed. Respondents indicated that they generally do not distribute GAP data in the original form. When asked if they ever direct anyone to the GAP web site to download data, respondents were roughly split between those who never do and those who do so several times a year.

When asked how frequently they distribute a product based on GAP data, respondents most frequently indicated they do so up to several times a year. However, the distribution is usually limited to a few people. The intended audience for these products is usually at the state level. 
The respondents to this survey indicated their role is primarily to provide information products to those who make policies and decisions affecting conservation and that they were most frequently not in a position to make decisions directly affecting conservation of biodiversity.

Respondents were asked several questions regarding possible future actions by GAP.

Respondents indicated that land cover is the most important database to keep current and that it is more important to update existing data than to create new data. Respondents generally agreed they would use new releases of GAP data. Having access to an individual to help with use of GAP data was viewed by respondents as being somewhat useful.

A section of the survey addressed outreach methods and included questions regarding a GAP conference, the "GAP Bulletin," and the GAP web site. Respondents indicated that cost, location, and topics covered would affect their attendance at a GAP conference. Respondents indicated it was generally unlikely that they would submit a presentation to, or attend, a GAP conference.

Most frequently respondents indicated they had never used information from the "GAP Bulletin" and that they were not familiar with the publication. The respondents who had used the "GAP Bulletin" indicated that the information had been somewhat useful and that the bulletin was a good quality information source.

Most survey respondents had visited the GAP web site at some time. They visited the web site primarily to obtain information or download data. They believed that visiting the web site met some or all of their needs.

A section of the survey included questions about GAP's reputation. Respondents generally disagreed that GAP is unknown to conservation professionals and the GIS user communities. GAP is perceived as having a generally positive reputation. However, when asked if GAP is losing ground to competing organizations, more than 50 percent of the respondents would neither agree nor disagree. When asked about the breadth of GAP's reputation, respondents believed that GAP has a state-level reputation but were less confident in judging GAP's reputation at the national or county/municipal levels. Respondents were asked what percentage of people who could use GAP data know about GAP. The most frequently selected response option was "Between 26 and 50 percent."

Respondents indicated they would recommend use of GAP data to others, and many of them already have. Those who have not recommended GAP to others indicated that the main reason was that no opportunity to do so had occurred.

The last section of the survey included questions regarding the goals and objectives of GAP. The respondents indicated that the most appropriate use for GAP data is to provide decisionmakers with knowledge about conservation issues and indicated that GAP data were most frequently used in that way.

Respondents were asked how helpful GAP data are or could be in addressing 21 different issues. The results varied on the basis of the issue. For seven of the issues, respondents most frequently indicated that they could not judge how helpful GAP data would be in addressing that issue.

Respondents generally agreed that GAP data are relevant to pending decisions relating to conservation of biodiversity and are compatible with existing policy-making processes. Respondents generally agreed that individuals who make decisions about conservation of biodiversity would be open to considering the types of information products that can be made using GAP data.

When asked to rate GAP's progress in meeting its objectives or grade GAP's performance on meeting cooperation and information dissemination goals, most frequently respondents indicated that they lacked the knowledge to make such judgments.

The nonresponse survey included a small set of questions from the primary survey and was sent to those who did not respond when the primary survey data were collected. The purpose of a 
nonresponse survey is to determine whether there are differences between those who responded to a survey and those who did not. Nearly one-half of those who answered the nonresponse survey are currently using GAP data or have used GAP data within the last 5 years. For those who are not currently using GAP data, the primary reason is because the data are not applicable to their current work. The respondents were most frequently employed by Federal agencies or universities. Respondents most frequently selected the term "ecology" to describe their current position. Most of these respondents were most familiar with data from state GAP projects. The type of data with which they were most familiar was land cover.

\section{Question Summaries}

The descriptive results for the survey questions are provided in the order in which the questions were asked. Because this was an adaptive survey, not all questions were asked of all respondents. Because some respondents skipped questions or did not complete the survey, the number of respondents $(n)$ who answered the question is provided. The percentage of respondents that selected each response option is provided. Percentages are rounded to whole numbers and therefore may not always add to 100. There are a few instances in which so few individuals selected a particular response that the percentages rounded down to zero. In those few situations, " $<0.5 \%$ " (less than 0.5 percent) is used to indicate that the response was selected by at least one respondent. If a response option is blank, no respondents selected that option. The responses selected most frequently are in bold type. Averages are provided when appropriate and are rounded to whole numbers.

The text of comments written by respondents for open-ended response questions is provided. When the open-ended responses were identical, the text of the response is provided and followed by a number in parentheses indicating the number of identical responses. To facilitate the ease of reading the comments, comments are grouped together into themes based on the content of the comment, when possible.

\section{Introductory Questions}

The first section of questions characterized the respondents' use of GAP data. The introductory questions were asked because knowing the respondents' level of use is critical to (1) accurately characterize the survey respondents and interpret their responses within the appropriate context and (2) direct respondents to appropriate questions later in the survey.

Q1 Which statement best describes your use of GAP data? $(n=359)$

\begin{tabular}{|l|c|}
\hline Response & Percent \\
\hline $\begin{array}{l}\text { a. I am using GAP data (either state, regional, or national data) at the present time, or have used it within the } \\
\text { last five (5) years. (Respondents selecting this response were directed to Q11 next.) }\end{array}$ & $\mathbf{6 4}$ \\
\hline $\begin{array}{l}\text { b. I last used GAP data (either state, or regional) more than five (5) years ago. (Respondents selecting this response } \\
\text { were directed to Q2 next.) }\end{array}$ & 17 \\
\hline c. I am familiar with GAP data but have not used it. (Respondents selecting this response were directed to Q2 next.) & 15 \\
\hline $\begin{array}{l}\text { d. I am not familiar with GAP and believe I have received this survey in error. (Respondents selecting this response } \\
\text { were directed to Q13 next.) }\end{array}$ & 3 \\
\hline
\end{tabular}



answer to Q1. If they selected option b for Q1, they were asked Q11 next; if they selected option c for Q1, they were asked Q13.

The respondents who selected options d through $\mathrm{k}$ for Q2 were asked a follow-up question specific to each option. These questions were designed to provide GAP with information about the concerns the users have with GAP data. This information will help GAP understand why past users and potential users of GAP data do not currently use GAP data. Although the follow-up questions were numbered Q3 through Q10, the responses to these questions are provided immediately after the corresponding response to Q2. Q3 through Q10 have open-ended responses. The comments are provided in their entirety. The alterations made to the comments include correction of spelling and grammar and removal of identifying information, when necessary, but capitalization and punctuation were not standardized.

The last three responses to Q2 did not have follow-up questions associated with them. As with options a through $\mathrm{c}$ for this question, respondents selecting options 1, m, or $\mathrm{n}$ to Q2 were next asked Q11 or Q13, depending on their answer to Q1.

\begin{tabular}{|c|c|}
\hline Response & Percent \\
\hline a. GAP data are not available for my area. & 4 \\
\hline b. GAP data are not applicable to the work l'm currently doing. & 53 \\
\hline c. GAP data are outdated. & 8 \\
\hline d. I have concerns about the content of the land-cover data. & 2 \\
\hline \multicolumn{2}{|l|}{ Q3: My main concern about the content of the land-cover data is $(n=4)$ : } \\
\hline \multicolumn{2}{|l|}{ The broad categories and difficulty of distinguishing wetland types and early successional types } \\
\hline \multicolumn{2}{|l|}{$\begin{array}{l}\text { My job no longer places me in a positon to be a judge of data quality. GAP data has been } \\
\text { valuable to us in the past, but my familiarity with it is not what it once was. I'd refer you to } \\
\text { others within our organization to give you a better perspective on its utility. }\end{array}$} \\
\hline \multicolumn{2}{|l|}{$\begin{array}{l}\text { I have no concerns about GAP data. I am a database administrator...but am not an end user of the } \\
\text { data. }\end{array}$} \\
\hline \multicolumn{2}{|l|}{ Accuracy at smaller scales. } \\
\hline e. I have concerns about the quality of the land-cover data. & 6 \\
\hline \multicolumn{2}{|l|}{ Q4: My main concern about the quality of the land-cover data is $(n=3)$ : } \\
\hline \multicolumn{2}{|l|}{ The GAP data I've seen have issues of class accuracy. } \\
\hline \multicolumn{2}{|l|}{ Not at an acceptable accuracy level for even statewide use. } \\
\hline \multicolumn{2}{|l|}{ I am not aware of a quality land cover dataset for Texas coming out of the GAP program. } \\
\hline \multicolumn{2}{|l|}{ f. I have concerns about the content of the predicted species distribution data. } \\
\hline \multicolumn{2}{|l|}{ Q5: My main concern about the content of the predicted species distribution data is $(n=0)$ : } \\
\hline g. I have concerns about the quality of the predicted species distribution data. & 2 \\
\hline \multicolumn{2}{|l|}{ Q6: My main concern about the quality of the predicted species distribution data is $(n=2)$ : } \\
\hline \multicolumn{2}{|l|}{$\begin{array}{l}\text { The GAP models aren't being kept up to date, the covariates associated with the predicted } \\
\text { distribution aren't well known, and there is no means of vetting the results. }\end{array}$} \\
\hline \multicolumn{2}{|l|}{ Models over-predict occurences. } \\
\hline h. I have concerns about the content of the stewardship/protected areas data. & 1 \\
\hline \multicolumn{2}{|l|}{ Q7: My main concern about the content of the stewardship/protected areas data is $(n=1)$ : } \\
\hline \multicolumn{2}{|l|}{ Distribution of species in protected areas. } \\
\hline \multicolumn{2}{|l|}{ i. I have concerns about the quality of the stewardship/protected areas data. } \\
\hline Q8: My main concern about the quality of the stewardship/protected areas data is $(n=0)$ : & \\
\hline
\end{tabular}




\begin{tabular}{|l|c|}
\hline j. GAP data are not compatible with the hardware that I use. & \\
\hline Q9: The hardware I use is $(n=0):$ & \\
\hline k. GAP data are not compatible with the other software packages I use. & \\
\hline Q10: The software package I use is $(n=1):$ & \\
\hline TEISS & 8 \\
\hline I. Lack of information on how to use GAP data. & \\
\hline m. Lack of support from my organization for use of GAP data. & 17 \\
\hline n. I use data similar to GAP data but that is provided by a different source. & \\
\hline
\end{tabular}

\section{How GAP Data Have Been Used}

Survey respondents were asked to identify how they used GAP data. GAP data are publicly available and can be obtained by anyone with internet access and appropriate software. Therefore, we could not assume how the data were being used.

Q11 Please indicate below the main issue that you used GAP data to address. ( $n=283)$

\begin{tabular}{|c|c|}
\hline 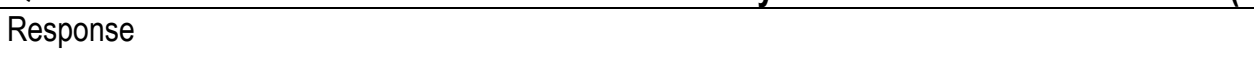 & Percent \\
\hline a. Agriculture & 1 \\
\hline b. Biodiversity conservation & 35 \\
\hline c. Climate change & 1 \\
\hline d. Ecological/Ecosystem monitoring & 12 \\
\hline \multicolumn{2}{|l|}{ e. Geology/Hydrology } \\
\hline f. Engineering/Construction/Surveying & 1 \\
\hline g. Fish and Wildlife management & 22 \\
\hline h. Fire management & 1 \\
\hline i. Forest management & 5 \\
\hline j. Invasive Species & $<0.5$ \\
\hline k. Mapping/Cartography & 8 \\
\hline \multicolumn{2}{|l|}{ I. Oil and gas/minerals exploration/extraction } \\
\hline m. Range/Grassland management & $<0.5$ \\
\hline \multicolumn{2}{|l|}{ n. Recreation management } \\
\hline o. Rural planning and development & 2 \\
\hline p. Transportation planning & $<0.5$ \\
\hline q. Urbanization (growth, sprawl, etc.) & 1 \\
\hline r. Water management (including coastal, wetland, and watershed management) & 3 \\
\hline s. Other: [open-ended response] $(n=19)$ & 7 \\
\hline \multicolumn{2}{|l|}{ Archaeological site location modeling } \\
\hline \multicolumn{2}{|l|}{ Archaeological modeling } \\
\hline \multicolumn{2}{|l|}{ Teaching } \\
\hline \multicolumn{2}{|l|}{ Environmental Education } \\
\hline \multicolumn{2}{|l|}{ In the context of Environmental Education/conservation education } \\
\hline \multicolumn{2}{|l|}{ Public health risk assessment } \\
\hline \multicolumn{2}{|l|}{ Planning and Permitting, EIS work } \\
\hline \multicolumn{2}{|l|}{ Conservation land acquisition } \\
\hline More specific land use and land class mapping and specific vegetation mapping & \\
\hline Land Use/ Land Cover Modeling & \\
\hline
\end{tabular}




\begin{tabular}{|l|l|}
\hline Ecosystem assessment & \\
\hline Integrated ecological assessment & \\
\hline Federal resources management & \\
\hline Resource Management Planning and renewable energy projects & \\
\hline Wetland restoration & \\
\hline State forest resource planning and criteria and indicators reporting & \\
\hline As ancillary data & \\
\hline Issues 2-4 in this list & \\
\hline Never used GAP data to address any issue & \\
\hline
\end{tabular}

Q12 Which option below most closely describes the purpose for which you used GAP datasets? $(n=281)$

\begin{tabular}{|l|c|}
\hline Response & Percent \\
\hline a. To provide information regarding conservation-related policy issues such as land use. & $\mathbf{3 7}$ \\
\hline b. To provide decisionmakers with knowledge about topics such as conservation concepts, models, or priorities. & 30 \\
\hline $\begin{array}{l}\text { c. To legitimize decisions, such as decisions about land use and land protection, made on the basis of other } \\
\text { information. }\end{array}$ & 14 \\
\hline d. To conduct academic research to fulfill course or degree requirements or for the purpose of publication. & 11 \\
\hline e. To conduct applied research that is conducted for some reason other than to inform conservation decisionmaking. & 8 \\
\hline
\end{tabular}

\section{Characteristics of Survey Respondents}

These questions addressed respondents' characteristics. The questions primarily address organization-level demographics. The few individual-level questions that were asked relate to use of GIS.

Q13 Which category best describes your organization? $(n=339)$

\begin{tabular}{|l|c|}
\hline Response & Percent \\
\hline a. Private (for profit) & 8 \\
\hline b. State & $\mathbf{3 0}$ \\
\hline c. University & 17 \\
\hline d. County & 2 \\
\hline e. Municipal & 1 \\
\hline f. Federal & 28 \\
\hline g. Non-profit & 12 \\
\hline h. Regional & $<0.5$ \\
\hline i. Tribal & $<0.5$ \\
\hline j. Other: [open-ended response] & 2 \\
\hline
\end{tabular}

Q14 How important is the conservation of biodiversity in the mission of your organization? $(n=337$, average $=4)$

\begin{tabular}{|c|c|c|c|c|}
\hline $\begin{array}{l}\text { a. Not important } \\
\text { (1) }\end{array}$ & $\begin{array}{l}\text { b. Slightly important } \\
\text { (2) }\end{array}$ & $\begin{array}{l}\text { c. Important } \\
\text { (3) }\end{array}$ & $\begin{array}{l}\text { d. Very important } \\
\text { (4) }\end{array}$ & $\begin{array}{l}\text { e. Critical } \\
\text { (5) }\end{array}$ \\
\hline $3 \%$ & $8 \%$ & $21 \%$ & $30 \%$ & $38 \%$ \\
\hline
\end{tabular}


Q15 Which field most closely describes your current position? $(n=339)$

\begin{tabular}{|c|c|}
\hline Response & Percent \\
\hline a. Ecology & 20 \\
\hline b. Biology & 7 \\
\hline c. Conservation & 14 \\
\hline d. GIS & 26 \\
\hline e. Land Use Planning & 3 \\
\hline f. Fish and Wildlife Management & 16 \\
\hline g. Land Management & 2 \\
\hline h Other: [open-ended response] $(n=42)$ & 12 \\
\hline \multicolumn{2}{|l|}{ Botany (3) } \\
\hline \multicolumn{2}{|l|}{ Statistics (2) } \\
\hline \multicolumn{2}{|l|}{ Administration } \\
\hline \multicolumn{2}{|l|}{ Agency Leadership and Management } \\
\hline \multicolumn{2}{|l|}{ Air Quality Management } \\
\hline \multicolumn{2}{|l|}{ Air Quality Planning } \\
\hline \multicolumn{2}{|l|}{ Climate research } \\
\hline \multicolumn{2}{|l|}{ Coastal Geology } \\
\hline \multicolumn{2}{|l|}{ Coastal Zone Management } \\
\hline \multicolumn{2}{|l|}{ Conservation Stewardship/Ecology } \\
\hline \multicolumn{2}{|l|}{ Data management } \\
\hline \multicolumn{2}{|l|}{ Economics } \\
\hline \multicolumn{2}{|l|}{ Education/Outreach in Fish and Wildlife Managment } \\
\hline \multicolumn{2}{|l|}{ Engineering Visualization Manager } \\
\hline \multicolumn{2}{|l|}{ Forestry } \\
\hline \multicolumn{2}{|l|}{ Geography } \\
\hline \multicolumn{2}{|l|}{ Human Dimensions } \\
\hline \multicolumn{2}{|l|}{ Information Technology } \\
\hline \multicolumn{2}{|l|}{ Interdisciplinary } \\
\hline \multicolumn{2}{|l|}{ Land Steward } \\
\hline \multicolumn{2}{|l|}{ Land Use and Land Cover Change } \\
\hline \multicolumn{2}{|l|}{ Landscape Architecture } \\
\hline \multicolumn{2}{|l|}{ Landscape ecology } \\
\hline \multicolumn{2}{|l|}{ Medical School } \\
\hline \multicolumn{2}{|l|}{ Natural Resources Secialist } \\
\hline \multicolumn{2}{|l|}{ Public health } \\
\hline Public Relations & \\
\hline Remote Sensing & \\
\hline Research & \\
\hline Science Advisor & \\
\hline Systematics & \\
\hline Water Quality and Watershed Management & \\
\hline Water Quality Planning \& Management & \\
\hline Water Resource Engineering & \\
\hline Water resources monitoring & \\
\hline
\end{tabular}




\begin{tabular}{|l|l|}
\hline Wetland restoration/ecological monitoring & \\
\hline I don't have a paid position & \\
\hline Ecology, Conservation, GIS, F \& W Management (in retirement) & \\
\hline No longer with the organization where I used the data & \\
\hline
\end{tabular}

\section{Q16 What is the journal, newsletter, or publication that you read most frequently to keep current in your field?} [open-ended response] $(n=235)$

Some respondents listed more than one publication. Each publication was counted separately.

Some respondents provided a response that was not the name of a publication.

\begin{tabular}{|c|c|}
\hline 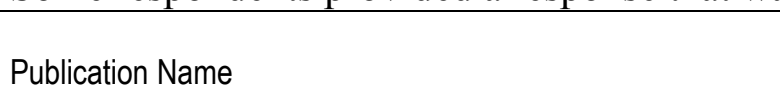 & $\begin{array}{c}\text { Number of times } \\
\text { named }\end{array}$ \\
\hline Journal of Wildlife Management & 43 \\
\hline Conservation Biology & 37 \\
\hline Ecology & 12 \\
\hline ArcNews & 11 \\
\hline ArcUser & 10 \\
\hline Photogrammetric Engineering and Remote Sensing & 8 \\
\hline ESRI materials & 7 \\
\hline Frontiers in Ecology and the Environment & 7 \\
\hline Science & 7 \\
\hline Landscape Ecology & 6 \\
\hline Fisheries & 5 \\
\hline The Auk & 5 \\
\hline The Condor & 4 \\
\hline Conservation & 3 \\
\hline Directions Magazine & 3 \\
\hline Forest Ecology and Management & 3 \\
\hline Nature & 3 \\
\hline Remote Sensing of Environment & 3 \\
\hline Restoration Ecology & 3 \\
\hline The Wildlife Society Bulletin & 3 \\
\hline Transactions of the American Fisheries Society & 3 \\
\hline Wildlife Professional & 3 \\
\hline Biological Conservation & 2 \\
\hline Bioscience & 2 \\
\hline Canadian Journal of Fisheries and Aquatic Sciences & 2 \\
\hline Ecological Applications & 2 \\
\hline Ecological Monitoring & 2 \\
\hline Imaging Notes & 2 \\
\hline Journal of Forestry & 2 \\
\hline Journal of Mammalogy & 2 \\
\hline Journal of the American Water Resources Association & 2 \\
\hline Journals from American Fisheries Society & 2 \\
\hline Landscape and Urban Planning & 2 \\
\hline Natural Areas Journal & 2 \\
\hline Rangeland Ecology and Management & 2 \\
\hline
\end{tabular}




\begin{tabular}{|c|c|}
\hline Society of American Foresters publications & 2 \\
\hline The Wildlife Society publications & 2 \\
\hline URISA Journal & 2 \\
\hline Wetlands & 2 \\
\hline Wilson Journal of Ornithology & 2 \\
\hline American Journal of Botany & 1 \\
\hline American Journal of Tropical Medicine and Hygiene & 1 \\
\hline American Society for Training and Development & 1 \\
\hline American Statistician & 1 \\
\hline Animal Conservation & 1 \\
\hline Annals of the Association of American Geographers & 1 \\
\hline APA (American Planning Assoc.) publications & 1 \\
\hline Arboriculture \& Urban Forestry (ISA, Champaign, IL) & 1 \\
\hline ArcWatch & 1 \\
\hline Association of Computing Machinery & 1 \\
\hline Audubon & 1 \\
\hline Bulletin of American Meteorologists & 1 \\
\hline Conservation Letters & 1 \\
\hline CQ & 1 \\
\hline Earth (formerly Geotimes) & 1 \\
\hline Ecography & 1 \\
\hline Ecological Engineering & 1 \\
\hline Ecological Modeling & 1 \\
\hline Endangered Species Bulletin & 1 \\
\hline Environmental History & 1 \\
\hline Environmental Modeling & 1 \\
\hline Environmental Toxicology and Chemistry & 1 \\
\hline ESA materials & 1 \\
\hline Evolution & 1 \\
\hline Fisheries Oceanography & 1 \\
\hline Forest Science & 1 \\
\hline GIS World & 1 \\
\hline GPS World & 1 \\
\hline High Country News & 1 \\
\hline International Journal of Geographic Information Science & 1 \\
\hline International Journal of Wildland Fire & 1 \\
\hline JEP & 1 \\
\hline Journal of Fish and Wildlife Management & 1 \\
\hline Journal of Air and Waste Management & 1 \\
\hline Journal of Applied Ecology & 1 \\
\hline Journal of Biogeography & 1 \\
\hline Journal of Coastal Research & 1 \\
\hline Journal of Environmental Economics and Management & 1 \\
\hline Journal of Field Ornithology & 1 \\
\hline Journal of Raptor Research & 1 \\
\hline
\end{tabular}




\begin{tabular}{|c|c|}
\hline Journal of the American Statistical Association & 1 \\
\hline Journal of the Linnean Society & 1 \\
\hline Native Plants Journal & 1 \\
\hline Natural Areas Management & 1 \\
\hline NC Conservation Network Bulletin & 1 \\
\hline NOAA Coastal Services Magazine & 1 \\
\hline North American Journal of Fisheries Management & 1 \\
\hline Northeastern Naturalist & 1 \\
\hline Oikos & 1 \\
\hline Park Science & 1 \\
\hline Partners In Flight stuff, national and regional & 1 \\
\hline Planning & 1 \\
\hline Plant Ecology & 1 \\
\hline PLoSOne & 1 \\
\hline Proceedings of the National Academy of Sciences, USA & 1 \\
\hline Review of Environmental Economics and Policy & 1 \\
\hline Revista de Biología Tropical & 1 \\
\hline Saving Land (Land Trust Alliance) & 1 \\
\hline Science News & 1 \\
\hline Society for Conservation Biology publications & 1 \\
\hline Society for Ecological Restoration publications & 1 \\
\hline Systematic Biology & 1 \\
\hline Systematic Botany & 1 \\
\hline The Conservationist & 1 \\
\hline The Wildlifer & 1 \\
\hline Urban Forestry \& Urban Greening & 1 \\
\hline Ursus & 1 \\
\hline Wilson Bulletin & 1 \\
\hline WMI Outdoor news bulletin & 1 \\
\hline \multicolumn{2}{|l|}{ Other comments made in response to this question that were not names of publications: } \\
\hline \multicolumn{2}{|l|}{ Theme: Multiple resources $(n=13)$} \\
\hline \multicolumn{2}{|l|}{ Multiple (2) } \\
\hline \multicolumn{2}{|l|}{ I read a combination of publications (all with equal frequency) to keep current in my field. } \\
\hline \multicolumn{2}{|l|}{ Many journals - there is no one source } \\
\hline \multicolumn{2}{|l|}{ Many journals and books } \\
\hline \multicolumn{2}{|l|}{ Many...it depends on the issues we are working. } \\
\hline \multicolumn{2}{|l|}{ Multiple journals, no one in particular } \\
\hline \multicolumn{2}{|l|}{ No single journal or newsletter---following many different sources } \\
\hline \multicolumn{2}{|l|}{ None in particular, there are a number of them } \\
\hline \multicolumn{2}{|l|}{ Read a variety of all of these } \\
\hline \multicolumn{2}{|l|}{ Various } \\
\hline \multicolumn{2}{|l|}{ Various taxa specific publications } \\
\hline \multicolumn{2}{|l|}{ Various wildlife management journals, newsletters, publications } \\
\hline \multicolumn{2}{|l|}{ Theme: Internet resources $(n=12)$} \\
\hline Internet & \\
\hline
\end{tabular}




\begin{tabular}{|l|l|}
\hline Links from aquatic invasive species listservs and newsletters & \\
\hline Developer blogs & \\
\hline EPA, USGS, ACWA and ECOS listservs & \\
\hline Google summaries from news organizations on conservation topics of interest & \\
\hline Mostly use internet searches & \\
\hline On line news from various sources & \\
\hline Online articles from a variety of resources & \\
\hline Probably messages on the wildlife transportation list serve & \\
\hline Through internet several pages & \\
\hline We use mostly the Internet & \\
\hline I do not read any one publication but read various articles from websites, webinars and & \\
\hline enewsletters & \\
\hline Theme: Not one in particular ( $n=3)$ & \\
\hline No single journal & \\
\hline Don't rely heavily on one journal. & \\
\hline I don't read any one journal more frequently than others. & \\
\hline Theme: None ( $n=3)$ & \\
\hline Theme: Communications with colleagues ( $n=2)$ & \\
\hline Climate science updates which are circulated by colleagues. & \\
\hline $\begin{array}{l}\text { Communication with members of the NC Conservation community and the network of natural } \\
\text { heritage programs }\end{array}$ & \\
\hline Theme: Depends on the topic ( $n=2)$ & \\
\hline I read by subject, not journal. \\
\hline Really depends on the topic of interest.
\end{tabular}

\section{Q17 In your current position, which of the following roles with respect to GIS data do you fill? Please select all} that apply. $(n=339)$

\begin{tabular}{|l|c|c|}
\hline Response & $\begin{array}{c}\text { Number of } \\
\text { times selected }\end{array}$ & Percent \\
\hline a. Acquire datasets & 193 & 57 \\
\hline b. Create datasets & 189 & 56 \\
\hline c. Maintain datasets & 144 & 42 \\
\hline d. Inventory datasets & 93 & 27 \\
\hline e. Distribute datasets & 143 & 42 \\
\hline f. Use datasets to create information products & $\mathbf{2 4 9}$ & $\mathbf{7 3}$ \\
\hline g. I do not have any roles with respect to GIS data & 42 & 12 \\
\hline
\end{tabular}

Q18 How long have you been using GIS technology? $(n=336$, average $=5)$

\begin{tabular}{|c|c|c|c|c|c|}
\hline a. Less than 1 year & b. 1-2 years & c. 3-5 years & d. 6-10 years & $\begin{array}{c}\text { e. More than } 10 \\
\text { years } \\
(\mathbf{5})\end{array}$ & $\begin{array}{c}\text { f. I have never used } \\
\text { GIS technology } \\
\text { (no value) }\end{array}$ \\
\hline (1) & $(2)$ & $(3)$ & $(4)$ & $\mathbf{6 8 \%}$ & $5 \%$ \\
\hline
\end{tabular}




\begin{tabular}{|l|c|}
\hline Response & Percent \\
\hline a. I am self-taught in GIS & $\mathbf{2 9}$ \\
\hline b. Informal on the job training from a co-worker & 18 \\
\hline c. Formal training provided by employer & 13 \\
\hline d. Professional seminar on GIS provided by company other than employer & 9 \\
\hline e. Formal undergraduate level GIS course & 8 \\
\hline f. Formal graduate level GIS course & 24 \\
\hline
\end{tabular}

At this point, the respondents who selected response d to Q1 (I am not familiar with GAP and believe I have received this survey in error) skipped forward in the survey to Q209.

Q20 What level of GIS skill is necessary to use GAP data? $(n=311)$

\begin{tabular}{|l|c|}
\hline Response & Percent \\
\hline a. No skill required & 5 \\
\hline b. Must have basic GIS skills & $\mathbf{6 4}$ \\
\hline c. Must have intermediate GIS skills & 29 \\
\hline d. Must have advanced GIS skills & 2 \\
\hline
\end{tabular}

\section{Acquisition of GAP Data}

Q21 How did you first learn about the types of GAP data available? $(n=322)$ Response

a. I was a partner in a state GAP project.

b. I learned about it in school and used it for school projects.

c. I found it online on the GAP web site.

d. I found an online link to GAP from another web site.

e. Someone I knew told me about it.

f. GAP data were referenced in a publication I read.

g. GAP data were referenced in a conference presentation I attended.

h. Other: [open-ended response]

Theme: Learned about GAP through connection with another person or agency $(n=19)$

Worked with colleagues that helped develop applications for use of GAP data

Work colleagues

Our consultants used it on our behalf for regional planning

My co-worker and supervisor who is an ornithologist was versed in GAP data

Minnesota Land Management (LMIC) \& MNDNR

Learned about it from other colleagues.

Learned about it at work

LCC meeting

I was supervised by a partner in a state GAP project

I took a job in a lab that ran a regional GAP project, but I had nothing to do with it.

GAP data used by conservation partners in joint project

GAP data are often mentioned within my agency

From colleagues working in GAP program

Followed the project since inception in other parts of US 


\begin{tabular}{|c|c|}
\hline Co-workers were partners in state GAP project & \\
\hline Cost-share project with The Nature Conservancy & \\
\hline Colleagues involved in the state GAP project. & \\
\hline I heard Mike Scott talk as he developed GAP years ago & \\
\hline Coworker participated in GAP development & \\
\hline Theme: Worked for GAP or with GAP as a partner or collaborator $(n=16)$ & \\
\hline Worked with U Arizona during initial development of GAP. & \\
\hline Provided local data & \\
\hline My state agency created the data & \\
\hline I was the PI for the ND GAP Analysis & \\
\hline I was contacted by USGS to groundtruth it in my area & \\
\hline I was an analyst and field worker for SWreGAP 2005 RS-GIS LAB USU & \\
\hline I was a staff member developing state GAP products & \\
\hline I was a research associate on our State GAP Project & \\
\hline I used to work for the GAP program & \\
\hline I provided data & \\
\hline I house the SEGAP program at the NC Coop Unit & \\
\hline I helped initiate GAP & \\
\hline I developed some of the datasets. & \\
\hline Early partner in national project. & \\
\hline Collaborator with GAP since its inception & \\
\hline Federal partner agency & \\
\hline Theme: GAP data was available at workplace $(n=8)$ & \\
\hline Work project utilizing GAP dataset & \\
\hline I re-ran the second set of models for a state gap project, but wasn't necessarily a partner & \\
\hline GAP data was in use at my work place. & \\
\hline GAP Data was available on the Forest where I worked & \\
\hline GAP data is available within my agency's data sets & \\
\hline GAP data are part of our core GIS library & \\
\hline Available on the Forest & \\
\hline Employer & \\
\hline Theme: Learned about GAP data as part of education $(n=5)$ & \\
\hline My major advisor was a state GAP coordinator. & \\
\hline Learned of it for use in masters thesis & \\
\hline It was part of my graduate school work & \\
\hline GAP was a big project at UCSB while I was there. & \\
\hline $\begin{array}{l}\text { Been using it for years. First heard about it in grad school, but never used it for any grad-related } \\
\text { projects. }\end{array}$ & \\
\hline Theme: Referenced affiliation with USGS $(n=5)$ & \\
\hline USGS staff from 1997 to 2005 & \\
\hline USGS Management & \\
\hline I was an original member of NBS and USGS BRD & \\
\hline I was a research associate on the USGS NBII project & \\
\hline I am a USGS employee & \\
\hline Theme: Cannot remember $(n=2)$ & \\
\hline
\end{tabular}




\begin{tabular}{|l|l|}
\hline I don't recall exactly. & \\
\hline I cannot remember---it has been too long. & \\
\hline Theme: Don't know what types of data are available $(n=2)$ & \\
\hline I have no idea what is available. & \\
\hline I don't know what types are available & \\
\hline No theme: & \\
\hline Became database administrator & \\
\hline
\end{tabular}

\section{Q22 What was the primary method you used to get GAP data that you use? $(n=318)$}

\begin{tabular}{|c|c|}
\hline Response & Percent \\
\hline a. It was distributed directly to me by the GAP program. & 26 \\
\hline b. I downloaded it off of the GAP web site. & 33 \\
\hline c. A colleague sent it to me. & 16 \\
\hline d. I am familiar with GAP data but have not used it. & 11 \\
\hline e. Other: [open-ended response] & 13 \\
\hline \multicolumn{2}{|l|}{ Theme: Created or produced data $(n=15)$} \\
\hline \multicolumn{2}{|l|}{ We created it (2) } \\
\hline \multicolumn{2}{|c|}{ When I used it, I was also the one creating the data coverages } \\
\hline \multicolumn{2}{|c|}{ We created or prepared most of it } \\
\hline \multicolumn{2}{|l|}{ Produced it } \\
\hline \multicolumn{2}{|l|}{ My unit created it so I had it locally. } \\
\hline \multicolumn{2}{|l|}{ I was the AZ PI and had the data in my posession } \\
\hline \multicolumn{2}{|l|}{ I was one of the PI's who created the data set for Hawaii } \\
\hline \multicolumn{2}{|l|}{ I helped create it. } \\
\hline \multicolumn{2}{|l|}{ I have access to data since we produce it } \\
\hline \multicolumn{2}{|l|}{ I generated the data } \\
\hline \multicolumn{2}{|l|}{ I developed it } \\
\hline \multicolumn{2}{|l|}{ Developed and used data } \\
\hline \multicolumn{2}{|l|}{ I was involved in creating the data sets } \\
\hline \multicolumn{2}{|l|}{ My organization contributes to the protected lands layer } \\
\hline \multicolumn{2}{|l|}{ Theme: Data is maintained by the agency or employer $(n=9)$} \\
\hline \multicolumn{2}{|l|}{ State GIS GAP layers on a central GIS drive } \\
\hline \multicolumn{2}{|l|}{ Obtained it from the GIS shop in our agency } \\
\hline \multicolumn{2}{|l|}{ My agency maintains it on the server. } \\
\hline \multicolumn{2}{|c|}{$\begin{array}{l}\text { It is incorporated into our available data sets. Our GIS people have taken GAP data and corrected } \\
\text { it where it was deficient to create a better dataset for our use. }\end{array}$} \\
\hline \multicolumn{2}{|c|}{ Internal datasharing services } \\
\hline \multicolumn{2}{|c|}{ GAP data are distributed as part of our state core GIS library } \\
\hline \multicolumn{2}{|c|}{ DNR has GAP data available for its employees on our data deli } \\
\hline \multicolumn{2}{|l|}{ Copies are stored on my agency's servers } \\
\hline \multicolumn{2}{|l|}{ Already available on BLM server } \\
\hline \multicolumn{2}{|l|}{ Theme: GAP data provided by some other source $(n=6)$} \\
\hline \multicolumn{2}{|l|}{ State of Minnesota provided it } \\
\hline \multicolumn{2}{|l|}{ My supervisee downloads it } \\
\hline \multicolumn{2}{|l|}{ Got if from UC Santa Barbara around the year 2000} \\
\hline Gap partner & \\
\hline
\end{tabular}




\begin{tabular}{|l|l|}
\hline GAP collaborators gave it to me & \\
\hline A Partnership Server & \\
\hline Theme: Downloaded from a different site $(n=4)$ & \\
\hline Utah GIS portal (AGRC) & \\
\hline Downloaded from MN DNR Site & \\
\hline Download from project web sites (SEGAP, ALGAP) & \\
\hline Downloaded from spatial data library & \\
\hline Theme: I have not used GAP data $(n=3)$ & \\
\hline I have never used GAP data. & \\
\hline I don't use it & \\
\hline Co-worker used it...not me & \\
\hline Theme: Multiple sources used to get GAP data $(n=2)$ & \\
\hline All of the above over time & \\
\hline We use multiple products. Some downloaded from web, some distributed directly & \\
\hline No theme: & \\
\hline I collected it and have down loaded data for other regions & \\
\hline Downloaded the GAP standards and created our own GAP database. & \\
\hline Do not remember & \\
\hline
\end{tabular}

\section{GAP Datasets-Geographic Sets of Data}

This section of the survey included questions that asked respondents about GAP datasets. In order to identify the dataset on which respondents were basing their responses, respondents were asked to identify the datasets with which they were most familiar. Respondents were directed to answer subsequent questions keeping in mind the dataset they had identified as the one with which they were most familiar.

First, respondents were asked to identify if they were most familiar with state, regional, or national GAP datasets. On the basis of the answer to that question, they were directed to survey questions specific to that level of data. If respondents answered that they were most familiar with state data, they were asked to identify the state. If respondents answered that they were most familiar with regional data, they were asked to identify the specific GAP regional project.

\section{Q23 With which geographic set of data are you most experienced or familiar? $(n=316)$}

\begin{tabular}{|c|c|c|c|}
\hline \multicolumn{3}{|l|}{ Response } & Percent \\
\hline \multicolumn{3}{|l|}{ a. State: } & 71 \\
\hline \multicolumn{4}{|c|}{ Please select the state or U.S. territory for the GAP dataset with which you are most familiar: $(n=220)$} \\
\hline Minnesota & 16 & $7 \%$ & \\
\hline Wyoming & 15 & $7 \%$ & \\
\hline Puerto Rico & 12 & $6 \%$ & \\
\hline North Carolina & 11 & $5 \%$ & \\
\hline lowa & 10 & $5 \%$ & \\
\hline Washington & 9 & $4 \%$ & \\
\hline Arizona & 8 & $4 \%$ & \\
\hline California & 7 & $3 \%$ & \\
\hline Idaho & 7 & $3 \%$ & \\
\hline
\end{tabular}




\begin{tabular}{|c|c|c|c|}
\hline Kentucky & 7 & $3 \%$ & \\
\hline Missouri & 7 & $3 \%$ & \\
\hline Colorado & 6 & $3 \%$ & \\
\hline Kansas & 6 & $3 \%$ & \\
\hline Florida & 5 & $2 \%$ & \\
\hline Illinois & 5 & $2 \%$ & \\
\hline Michigan & 5 & $2 \%$ & \\
\hline New York & 5 & $2 \%$ & \\
\hline Pennsylvania & 5 & $2 \%$ & \\
\hline Wisconsin & 5 & $2 \%$ & \\
\hline Alaska & 4 & $2 \%$ & \\
\hline Arkansas & 4 & $2 \%$ & \\
\hline Hawaii & 4 & $2 \%$ & \\
\hline Nebraska & 4 & $2 \%$ & \\
\hline Texas & 4 & $2 \%$ & \\
\hline Vermont & 4 & $2 \%$ & \\
\hline Alabama & 3 & $1 \%$ & \\
\hline Maine & 3 & $1 \%$ & \\
\hline Montana & 3 & $1 \%$ & \\
\hline New Mexico & 3 & $1 \%$ & \\
\hline Oklahoma & 3 & $1 \%$ & \\
\hline Oregon & 3 & $1 \%$ & \\
\hline South Dakota & 3 & $1 \%$ & \\
\hline Indiana & 2 & $1 \%$ & \\
\hline Louisiana & 2 & $1 \%$ & \\
\hline Nevada & 2 & $1 \%$ & \\
\hline New Hampshire & 2 & $1 \%$ & \\
\hline North Dakota & 2 & $1 \%$ & \\
\hline Ohio & 2 & $1 \%$ & \\
\hline South Carolina & 2 & $1 \%$ & \\
\hline Tennessee & 2 & $1 \%$ & \\
\hline Utah & 2 & $1 \%$ & \\
\hline West Virginia & 2 & $1 \%$ & \\
\hline Delaware & 1 & $1 \%$ & \\
\hline Mississippi & 1 & $1 \%$ & \\
\hline New Jersey & 1 & $1 \%$ & \\
\hline Virginia & 1 & $1 \%$ & \\
\hline b. Regional: & & & 20 \\
\hline \multicolumn{4}{|c|}{ Please select the regional GAP dataset with which you are most familiar: $(n=59)$} \\
\hline Southwest & 30 & $51 \%$ & \\
\hline Northwest & 15 & $25 \%$ & \\
\hline Southeast & 14 & $24 \%$ & \\
\hline c. National: & & & 10 \\
\hline
\end{tabular}


Respondents who were familiar with state data were next asked Q27. Respondents who were familiar with regional data were next asked Q24, and respondents who were familiar with national data were next asked Q30.

\section{Questions about Regional Datasets}

Q24 I prefer regional datasets because they are more accurate than state data. $(n=59$, average $=3)$

\begin{tabular}{|c|c|c|c|c|}
\hline a. Strongly disagree & b. Somewhat disagree & $\begin{array}{c}\text { c. Neither agree nor } \\
\text { disagree } \\
(3)\end{array}$ & $\begin{array}{c}\text { d. Somewhat agree } \\
(4)\end{array}$ & e. Strongly agree \\
\hline$(1)$ & $(2)$ & $\mathbf{5 0 \%}$ & $19 \%$ & $(5)$ \\
\hline $7 \%$ & $15 \%$ & & $10 \%$ \\
\hline
\end{tabular}

Q25 I use regional datasets because they are more current than state data. ( $n=56$, average $=3$ )

\begin{tabular}{|c|c|c|c|c|}
\hline a. Strongly disagree & $\begin{array}{c}\text { b. Somewhat disagree } \\
(1)\end{array}$ & $\begin{array}{c}\text { c. Neither agree nor } \\
\text { disagree } \\
(3)\end{array}$ & $\begin{array}{c}\text { d. Somewhat agree } \\
(4)\end{array}$ & e. Strongly agree \\
\hline $7 \%$ & $14 \%$ & $\mathbf{3 8 \%}$ & $25 \%$ & $(5)$ \\
\hline
\end{tabular}

Q26 Regional datasets meet my needs for data more closely than state data. ( $n=56$, average $=4$ )

\begin{tabular}{|c|c|c|c|c|}
\hline $\begin{array}{c}\text { a. Strongly disagree } \\
\text { (1) }\end{array}$ & $\begin{array}{l}\text { b. Somewhat disagree } \\
\text { (2) }\end{array}$ & $\begin{array}{l}\text { c. Neither agree nor } \\
\text { disagree } \\
\text { (3) }\end{array}$ & $\begin{array}{c}\text { d. Somewhat agree } \\
\text { (4) }\end{array}$ & $\begin{array}{c}\text { e. Strongly agree } \\
\text { (5) }\end{array}$ \\
\hline $2 \%$ & $2 \%$ & $11 \%$ & $34 \%$ & $52 \%$ \\
\hline
\end{tabular}

\section{Questions about State Datasets}

Q27 I prefer state datasets because they are more accurate than regional data. $(n=217$, average $=4)$

\begin{tabular}{|c|c|c|c|c|}
\hline $\begin{array}{c}\text { a. Strongly disagree } \\
(1)\end{array}$ & $\begin{array}{c}\text { b. Somewhat disagree } \\
(2)\end{array}$ & $\begin{array}{c}\text { c. Neither agree nor } \\
\text { disagree } \\
(3)\end{array}$ & $\begin{array}{c}\text { d. Somewhat agree } \\
(4)\end{array}$ & e. Strongly agree \\
\hline $2 \%$ & $6 \%$ & $\mathbf{5 3 \%}$ & $24 \%$ & $(5)$ \\
\hline
\end{tabular}

Q28 State datasets meet my needs for data more closely than regional data. $(n=217$, average $=4)$

\begin{tabular}{|c|c|c|c|c|}
\hline $\begin{array}{l}\text { a. Strongly disagree } \\
\text { (1) }\end{array}$ & $\begin{array}{l}\text { b. Somewhat disagree } \\
\text { (2) }\end{array}$ & $\begin{array}{l}\text { c. Neither agree nor } \\
\text { disagree } \\
\text { (3) }\end{array}$ & $\begin{array}{c}\text { d. Somewhat agree } \\
\text { (4) }\end{array}$ & $\begin{array}{l}\text { e. Strongly agree } \\
\text { (5) }\end{array}$ \\
\hline $2 \%$ & $4 \%$ & $24 \%$ & $34 \%$ & $37 \%$ \\
\hline
\end{tabular}

Q29 There are no regional data available for my location. ( $n=213$, average $=3$ )

\begin{tabular}{|c|c|c|c|c|}
\hline a. Strongly disagree & $\begin{array}{c}\text { b. Somewhat disagree } \\
(1)\end{array}$ & $\begin{array}{c}\text { c. Neither agree nor } \\
\text { disagree } \\
(3)\end{array}$ & $\begin{array}{c}\text { d. Somewhat agree } \\
\text { e. Strongly agree }\end{array}$ & $(4)$ \\
\hline $18 \%$ & $10 \%$ & $\mathbf{5 8 \%}$ & $7 \%$ & $8 \%$ \\
\hline
\end{tabular}




\section{Questions about National Datasets}

Q30 I use the new national datasets because the national data is the most recently produced dataset. $(n=24$, average $\mathbf{~ 4 )}$

\begin{tabular}{|c|c|c|c|c|}
\hline $\begin{array}{l}\text { a. Strongly disagree } \\
\text { (1) }\end{array}$ & $\begin{array}{l}\text { b. Somewhat disagree } \\
\text { (2) }\end{array}$ & $\begin{array}{l}\text { c. Neither agree nor } \\
\text { disagree } \\
\text { (3) }\end{array}$ & $\begin{array}{l}\text { d. Somewhat agree } \\
\text { (4) }\end{array}$ & $\begin{array}{l}\text { e. Strongly agree } \\
\text { (5) }\end{array}$ \\
\hline & $8 \%$ & $38 \%$ & $38 \%$ & $17 \%$ \\
\hline
\end{tabular}

Q31 I use the new national datasets because I need data that is consistent at a national scale. $(n=25$, average $=4$ )

\begin{tabular}{|c|c|c|c|c|}
\hline a. Strongly disagree & $\begin{array}{c}\text { b. Somewhat disagree } \\
(1)\end{array}$ & $\begin{array}{c}\text { c. Neither agree nor } \\
\text { disagree } \\
(3)\end{array}$ & $\begin{array}{c}\text { d. Somewhat agree } \\
\text { e. Strongly agree }\end{array}$ & (4) \\
\hline & $(2)$ & $20 \%$ & $24 \%$ & $\mathbf{5 6 \%}$ \\
\hline
\end{tabular}

Q32 I use the new national datasets because the way that national data is provided on the GAP web site makes it easier to access and use than the state or regional datasets. $(n=25$, average $=3$ )

\begin{tabular}{|c|c|c|c|c|}
\hline $\begin{array}{l}\text { a. Strongly disagree } \\
\text { (1) }\end{array}$ & $\begin{array}{c}\text { b. Somewhat disagree } \\
\text { (2) }\end{array}$ & $\begin{array}{l}\text { c. Neither agree nor } \\
\text { disagree } \\
\text { (3) }\end{array}$ & $\begin{array}{l}\text { d. Somewhat agree } \\
\text { (4) }\end{array}$ & $\begin{array}{l}\text { e. Strongly agree } \\
\text { (5) }\end{array}$ \\
\hline $4 \%$ & & $56 \%$ & $24 \%$ & $16 \%$ \\
\hline
\end{tabular}

\section{GAP Datasets-Types of Data}

Within the different geographic levels of GAP data (state, regional, and national), GAP produces multiple types of data. Respondents were asked with which type of data they had the most experience or with which type they were most familiar. This question permitted the identification of the type of GAP data the respondents were using as the basis for their responses to the survey questions and permitted the survey to be adapted to the specific background of the respondent.

Q33 With which type of GAP data are you most experienced or familiar? $(n=304)$

\begin{tabular}{|l|c|}
\hline Response & Percent \\
\hline a. Land cover & $\mathbf{5 7}$ \\
\hline b. Predicted Species Distributions & 22 \\
\hline c. Stewardship/protected areas & 10 \\
\hline d. Analysis (Land cover + Predicted Species Distribution + Stewardship/protected areas) & 11 \\
\hline
\end{tabular}

Q34 The GAP data I need for my area are available. ( $n=303$, average 4$)$

\begin{tabular}{|c|c|c|c|c|}
\hline $\begin{array}{l}\text { a. Strongly disagree } \\
\text { (1) }\end{array}$ & $\begin{array}{l}\text { b. Somewhat disagree } \\
\text { (2) }\end{array}$ & $\begin{array}{l}\text { c. Neither agree nor } \\
\text { disagree } \\
\text { (3) }\end{array}$ & $\begin{array}{l}\text { d. Somewhat agree } \\
\text { (4) }\end{array}$ & $\begin{array}{l}\text { e. Strongly agree } \\
\text { (5) }\end{array}$ \\
\hline $4 \%$ & $7 \%$ & $15 \%$ & $38 \%$ & $37 \%$ \\
\hline
\end{tabular}


Q35 I have to add to GAP datasets or manipulate the data to make it useful. ( $n=304$, average 3)

\begin{tabular}{|c|c|c|c|c|}
\hline $\begin{array}{l}\text { a. Strongly disagree } \\
\text { (1) }\end{array}$ & $\begin{array}{l}\text { b. Somewhat disagree } \\
\text { (2) }\end{array}$ & $\begin{array}{l}\text { c. Neither agree nor } \\
\text { disagree } \\
\text { (3) }\end{array}$ & $\begin{array}{l}\text { d. Somewhat agree } \\
\text { (4) }\end{array}$ & $\begin{array}{l}\text { e. Strongly agree } \\
\text { (5) }\end{array}$ \\
\hline $8 \%$ & $14 \%$ & $31 \%$ & $38 \%$ & $9 \%$ \\
\hline
\end{tabular}
question.

If respondents agreed either somewhat or strongly with Q35, they were asked Q36 as a follow up

\section{Q36 What change or manipulation do you usually make to GAP data in order to make it useful? [open-ended response] $(n=114)$.}

Several respondents made multiple comments. If a respondent made multiple comments, the comments were split into independent components before the responses were summarized.

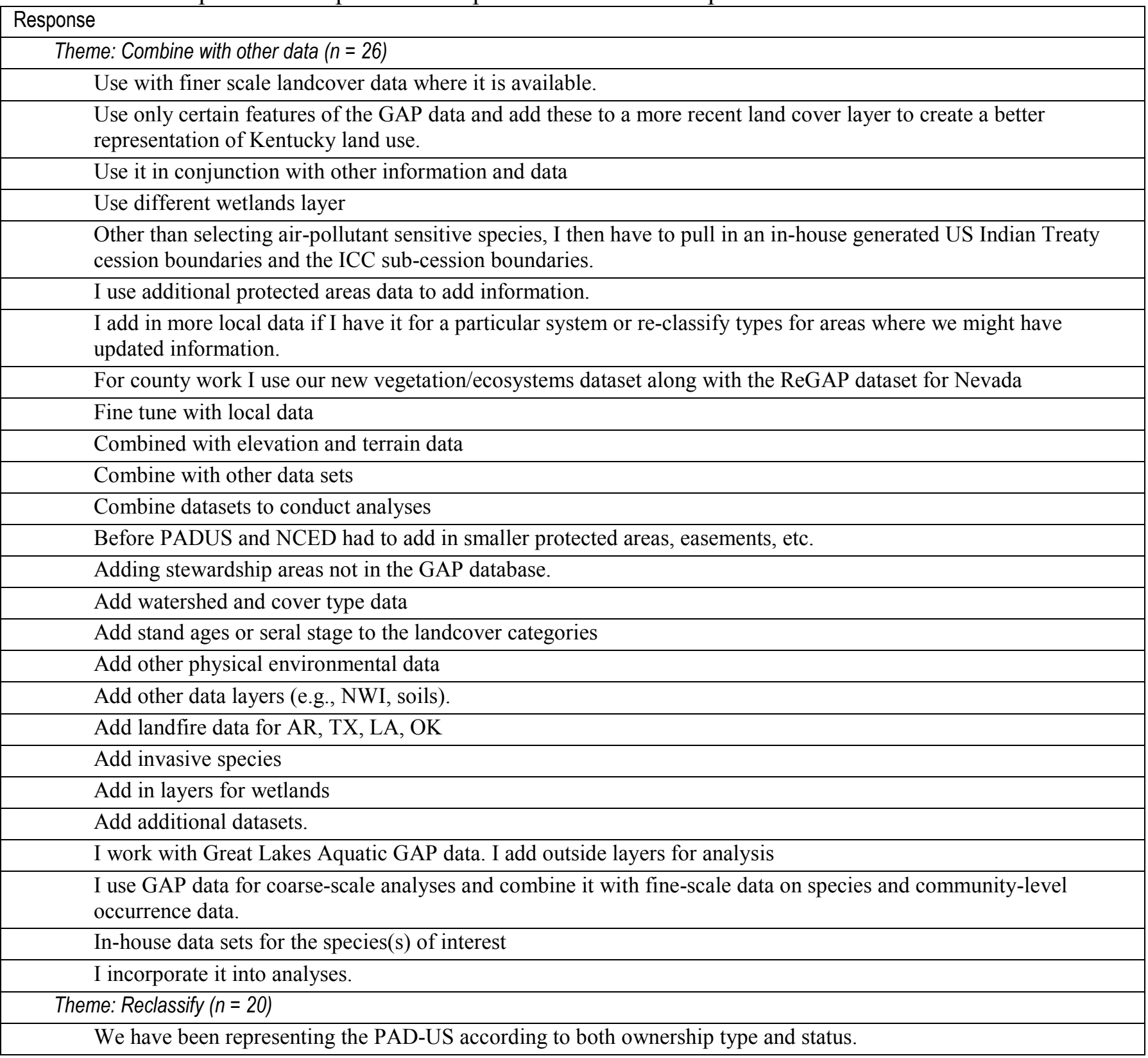




\begin{tabular}{|c|}
\hline Reclassify to appropriate level of correctness \\
\hline Reclassify the map \\
\hline $\begin{array}{l}\text { Re-classify legend into a one-to-many, many-to-one step up that lines up with a state ecological classification } \\
\text { system }\end{array}$ \\
\hline Reclassify incorrectly identified landcover types \\
\hline Reclassification to consolidate Level 4 to Level 3 in most instances because Level 4 resolution is unrealistic \\
\hline Reclassification to (simpler) themes that are useful to conservation planning. \\
\hline Reclassification of vegetation types. Modifying species distribution models \\
\hline Reclassification \\
\hline $\begin{array}{l}\text { For the landcover dataset, the detail within the cover types are often too specific or with names that are convoluted. } \\
\text { I commonly have to combine or rename several veg. types into groups of similar classes to make it useful for } \\
\text { presentation/communication with non GAP users. }\end{array}$ \\
\hline Collapse/expand land cover categories \\
\hline Aggregation of cover types \\
\hline Aggregate to categories needed for my investigation. \\
\hline Aggregate some lc types to match more current lc data so comparisons can be made over time \\
\hline Aggregating land cover categories that were too similar \\
\hline $\begin{array}{l}\text { "Lump" categories to make them more appropriate to my needs or simply have a smaller (less unwieldy) number of } \\
\text { categories to deal with. }\end{array}$ \\
\hline More detailed landcover down to forest community types, inundation data, \\
\hline $\begin{array}{l}\text { We have added in protected areas that are missing in the PAD. We have changed the status rank on some areas } \\
\text { based on local expert knowledge }\end{array}$ \\
\hline Lump or split some cover types \\
\hline Grouping LULC categories to cross-walk with Canadian datasets \\
\hline Theme: Update $(n=11)$ \\
\hline Updating species models, PAD, and land cover \\
\hline Updating \\
\hline Updated and better done. \\
\hline Update with more training data \\
\hline Update species distributions \\
\hline Update land management status. \\
\hline Intersect it with other more current data. \\
\hline Augment with more recent data layers. \\
\hline Add more recent data. \\
\hline Replace it with updated data that I've collected. \\
\hline More specific, localized information/ updated data \\
\hline Theme: Correct accuracy $(n=10)$ \\
\hline $\begin{array}{l}\text { Oak is overrepresented in the Willamette Valley ecological systems coverage. I have used ancillary datasets to } \\
\text { remove pixels of oak for which support is weak that oak do indeed exist there. }\end{array}$ \\
\hline $\begin{array}{l}\text { Land cover is not always accurate. Particularly for sub-state level (e.g., multi-county) analyses, I have had to correct } \\
\text { the more egregious departures from reality. The categories of "recently burned" or "recently chained" are also of } \\
\text { minimal use and need to be reclassified to an actual land cover (not a land management activity). }\end{array}$ \\
\hline $\begin{array}{l}\text { Identifying and fixing issues of misclassification in the landscover map, and extending wildlife models into areas } \\
\text { that have not been updated. }\end{array}$ \\
\hline $\begin{array}{l}\text { I correct GAP land cover classification errors by referencing other datasets, both vector and raster. For example, } \\
\text { MnDOT data is used to improve the GAP built-up areas, and NWI data is used to distinquish upland and wetland } \\
\text { natural land cover types. }\end{array}$ \\
\hline
\end{tabular}




\begin{tabular}{|c|}
\hline $\begin{array}{l}\text { GAP land cover data for Florida are full of errors and are now out of date relative to other land cover data layers } \\
\text { available for the state. Thus, GAP data are not very useful for Florida. }\end{array}$ \\
\hline Corrected misclassifications, added land cover types \\
\hline Change land cover types and areas as needed from groundtruthing. \\
\hline Correcting omissions in land status layer \\
\hline Spatial clean up of specific type distributions based on field knowledge and samples data \\
\hline $\begin{array}{l}\text { Southwest ReGAP is generally based on NM. In AZ we have found errors in Veg data and have had to correct it. } \\
\text { Also, the species distributions are often way out of line with what we know about actual distributions and must be } \\
\text { corrected to be useful }\end{array}$ \\
\hline Theme: Refine $(n=6)$ \\
\hline Simple modifications to species examined, buffers, etc. \\
\hline Refining predicted species distributions. \\
\hline I smooth the data when I need to generalize \\
\hline Filter techniques applied to landcover \\
\hline Clean up field and farm boundaries \\
\hline Editing some land cover where better information is available; editing protected areas database \\
\hline Theme: None $(n=6)$ \\
\hline None (2) \\
\hline Was not possible to use it for accurate characterization of upland cover types \\
\hline $\begin{array}{l}\text { I'm not really using it any more, and never really did. Was aware of it, but was not specific enough to suit my } \\
\text { needs. }\end{array}$ \\
\hline $\begin{array}{l}\text { The state and regional data are not sufficient for Pima County information. We have created our own GAP } \\
\text { stewardship database based on GAP standards. }\end{array}$ \\
\hline We are developing our own land cover/ecological Systems \\
\hline Theme: Clip $(n=5)$ \\
\hline Clipping, conversion to another file type \\
\hline Clip to State Boundaries \\
\hline Clip land cover dataset to state, to reduce file size \\
\hline Clip it to project areas \\
\hline $\begin{array}{l}\text { Clip and zip from the national dataset. I need a state plus buffer, and must download all surrounding states and then } \\
\text { clip. }\end{array}$ \\
\hline Theme: Merge/edge matching $(n=5)$ \\
\hline Sometime I have to include portions of other states or remove a portion of a region. \\
\hline Merge datasets or regions together, i.e. states needed merging \\
\hline Edge matching across political boundaries (when regional datasets were not available) \\
\hline I had to stitch together multiple state datasets to create regional data requiring a crosswalk of cover types. \\
\hline We had to crosswalk KS and MO data \\
\hline Theme: Selective use $(n=4)$ \\
\hline $\begin{array}{l}\text { Typically I need to select data for only certain species as well as data for particular species use areas (i.e., breeding } \\
\text { habitat) }\end{array}$ \\
\hline $\begin{array}{l}\text { Applications require that I buffer or select data to conform with sampling schemes. It is not that the landcover data } \\
\text { need to be changed. }\end{array}$ \\
\hline Selecting certain attribute fields of interest, clipping and recalculating acreage, overlaying \\
\hline Extract specific lists of vertebrate species from species codes. \\
\hline Theme: Validate/groundtruth $(n=3)$ \\
\hline Validate for accuracy of location. \\
\hline Data accuracy verification through comparison with other datasets \\
\hline
\end{tabular}




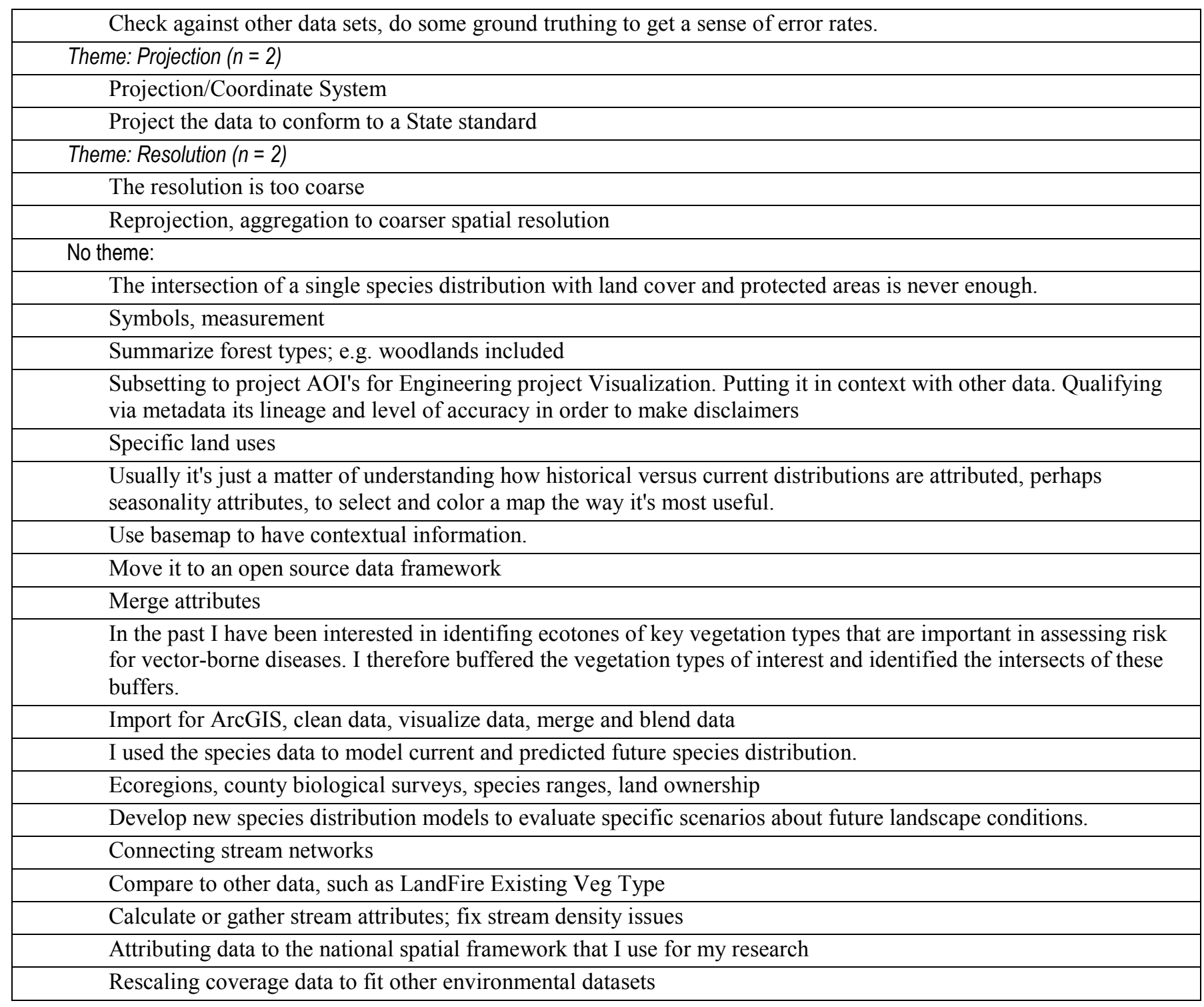

Q37 In using GIS data in general, what extent (area of interest) do you most commonly use? The words "county" and "state" in response options are only given for general reference. $(n=294)$

\begin{tabular}{|l|c|}
\hline Response & Percent \\
\hline a. Smaller than a county & 16 \\
\hline b. About the size of a single county & 9 \\
\hline c. Multiple counties & 20 \\
\hline d. State & $\mathbf{3 2}$ \\
\hline e. Multiple states & 16 \\
\hline f. National & 7 \\
\hline
\end{tabular}

Q38 In using GAP data, what extent (area of interest) do you most commonly use? The words "county" and "state" in response options are only given for general reference. $(n=248)$

Response

a. Smaller than a county

Percent 


\begin{tabular}{|l|c|}
\hline b. About the size of a single county & 13 \\
\hline c. Multiple counties & 27 \\
\hline d. State & $\mathbf{4 0}$ \\
\hline e. Multiple states & 8 \\
\hline f. National & 8 \\
\hline
\end{tabular}

At this point in the survey, respondents were directed to specific sets of questions depending upon their answer to Q33 which indicated with what type of GAP data they were most familiar. Respondents who indicated they were most familiar with land-cover data were directed to Q39. Respondents who indicated they were most familiar with predicted species distribution data were directed to Q59. Respondents who indicated they were most familiar with stewardship/protected areas data were directed to Q84, and respondents who indicated they were most familiar with GAP analysis data were directed to Q105.

\section{Land-Cover Data}

Q39 GAP land-cover data are useful at the following levels (select all that apply). $(n=167)$

\begin{tabular}{|c|c|c|}
\hline Response & $\begin{array}{l}\text { Number of } \\
\text { times selected }\end{array}$ & Percent \\
\hline a. National & 76 & 46 \\
\hline b. Regional & 115 & 69 \\
\hline c. Ecosystem & 101 & 60 \\
\hline d. State & 127 & 76 \\
\hline e. County & 87 & 52 \\
\hline f. Refuge & 31 & 19 \\
\hline g. Other: [open-ended response] & 14 & 8 \\
\hline \multicolumn{3}{|l|}{ Theme: Watershed $(n=3)$} \\
\hline \multicolumn{3}{|l|}{ Watershed } \\
\hline \multicolumn{3}{|l|}{ Large (e.g., western) counties or similar sized watersheds } \\
\hline \multicolumn{3}{|l|}{ At level 12 hydrologic water catchment area } \\
\hline \multicolumn{3}{|l|}{ Theme: Conservation easement $(n=2)$} \\
\hline \multicolumn{3}{|l|}{ Conservation property (for example, conservation easement on a ranch) } \\
\hline \multicolumn{3}{|l|}{ Conservation Easement } \\
\hline \multicolumn{3}{|l|}{ Theme: Depends on purpose $(n=2)$} \\
\hline \multicolumn{3}{|l|}{$\begin{array}{l}\text { Question has multiple contexts for me. For Engineering projects, county size or } \\
\text { less is relevant, but for some uses it must be put in larger context, and obviously } \\
\text { ecosystems/habitat does not stop at arbitrary political boundaries }\end{array}$} \\
\hline \multicolumn{3}{|l|}{ Depends on the purpose } \\
\hline \multicolumn{3}{|l|}{ Theme: No opinion $(n=2)$} \\
\hline \multicolumn{3}{|l|}{$\begin{array}{l}\text { I have only been involved in one project that we used land cover data at the state } \\
\text { level, I don't really have an opinion due to lack of knowledge }\end{array}$} \\
\hline \multicolumn{3}{|l|}{ I do not use GAP data and do not have an opinion } \\
\hline \multicolumn{3}{|l|}{ No theme: } \\
\hline \multicolumn{3}{|l|}{ National Forest } \\
\hline $\begin{array}{l}\text { Multi-county, esp. those that cross state lines. Also, by "ecosystem" I assume you } \\
\text { mean an ecoregion that crosses mutliple states. }\end{array}$ & & \\
\hline In cases where that is all that is available & & \\
\hline
\end{tabular}




\begin{tabular}{|l|l|l|}
\hline ECS subsection & & \\
\hline BLM District, BLM Field Office levels & & \\
\hline
\end{tabular}

Q40 GAP land-cover data are necessary at the following levels (select all that apply): $(n=164)$

\begin{tabular}{|l|c|c|}
\hline Response & $\begin{array}{c}\text { Number of } \\
\text { times selected }\end{array}$ & Percent \\
\hline a. National & 92 & 56 \\
\hline b. Regional & 115 & 70 \\
\hline c. Ecosystem & 103 & 63 \\
\hline d. State & $\mathbf{1 1 9}$ & $\mathbf{7 3}$ \\
\hline e. County & 89 & 54 \\
\hline f. Refuge & 38 & 23 \\
\hline g. Other: [open-ended response] & 13 & 8 \\
\hline Theme: Questioning "necessary" (n=2) & & \\
\hline Unclear what is implied by 'necessary' - 'the only option'? & & \\
\hline Huh? You are assuming it is 'necessary'. & & \\
\hline Theme: No opinion (n = 2) & & \\
\hline No informed opinion & & \\
\hline I do not use GAP data and do not have an opinion & & \\
\hline No theme: & & \\
\hline Watershed & & \\
\hline Varies a lot and depends on area of state & & \\
\hline Not necessary at any level & & \\
\hline $\begin{array}{l}\text { Multi-county, esp. those that cross state lines. Also, by "ecosystem" I assume you } \\
\text { mean an ecoregion that crosses mutliple states. }\end{array}$ & & \\
\hline In cases where that is all that is available & & \\
\hline Depends on the purpose & & \\
\hline Conservation Easement & & \\
\hline BLM District, BLM Field Offices levels & & \\
\hline Any property of ecological significance & & \\
\hline
\end{tabular}

Q41 How important is it to have consistent seamless national coverage of vegetation? $(n=167$, average $=4)$

\begin{tabular}{|c|c|c|c|c|}
\hline $\begin{array}{c}\text { a. Not important } \\
(1)\end{array}$ & $\begin{array}{c}\text { b. Slightly important } \\
(2)\end{array}$ & $\begin{array}{c}\text { c. Important } \\
(3)\end{array}$ & $\begin{array}{c}\text { d. Very important } \\
(\mathbf{4})\end{array}$ & $\begin{array}{c}\text { e. Critical } \\
(5)\end{array}$ \\
\hline $3 \%$ & $7 \%$ & $22 \%$ & $\mathbf{4 0 \%}$ & $28 \%$ \\
\hline
\end{tabular}

Q42 How frequently should GAP land-cover data be produced? $(n=169)$

\begin{tabular}{|c|c|}
\hline Response & Percent \\
\hline a. Yearly & 7 \\
\hline b. Every 2-4 years & 34 \\
\hline c. Every 5-7 years & 47 \\
\hline d. Every $8-10$ years & 7 \\
\hline e. Other: [open-ended response] & 5 \\
\hline \multicolumn{2}{|l|}{ Theme: Approximately 5 years $(n=3)$} \\
\hline Five to seven year but also do the timing relative to socioeconomic data from the Census folks & \\
\hline As often as possible; at least every 5 years & \\
\hline
\end{tabular}




\begin{tabular}{|l|l|}
\hline 5 years intervals would be ok & \\
\hline Theme: No opinion $(n=2)$ & \\
\hline I do not use GAP data and do not have an opinion & \\
\hline Have only used data once, don't know enough about land data to make an informed decision & \\
\hline No theme: & \\
\hline Never - stop doing it and let LandFire/NatureServe do it & \\
\hline I have yet to see a finished product for Maryland or the northeast & \\
\hline Depends on how frequently land cover changes & \\
\hline
\end{tabular}

Q43 For my purposes, GAP land-cover data are relevant. ( $n=164$, average $=4)$

\begin{tabular}{|c|c|c|c|c|}
\hline $\begin{array}{c}\text { a. Strongly disagree } \\
(1)\end{array}$ & $\begin{array}{c}\text { b. Somewhat disagree } \\
(2)\end{array}$ & $\begin{array}{c}\text { c. Neither agree nor } \\
\text { disagree } \\
(3)\end{array}$ & $\begin{array}{c}\text { d. Somewhat agree } \\
\text { e. Strongly agree }\end{array}$ & $(4)$ \\
\hline $3 \%$ & $2 \%$ & $10 \%$ & $34 \%$ & $\mathbf{5 1}$ \\
\hline
\end{tabular}

Q44 I believe that GAP land-cover data are reliable. Reliable data are accurate, complete, dependable, and consistent. $(n=165$, average $=4)$

\begin{tabular}{|c|c|c|c|c|}
\hline a. Strongly disagree & b. Somewhat disagree & $\begin{array}{c}\text { c. Neither agree nor } \\
\text { disagree } \\
(3)\end{array}$ & $\begin{array}{c}\text { d. Somewhat agree } \\
\text { e. Strongly agree }\end{array}$ & (4) \\
\hline$(1)$ & $(2)$ & $18 \%$ & $\mathbf{5 3 \%}$ & $12 \%$ \\
\hline
\end{tabular}

Q45 Appropriate processes were used to assemble GAP land-cover data. ( $n=165$, average $=4$ )

\begin{tabular}{|c|c|c|c|c|}
\hline $\begin{array}{c}\text { a. Strongly disagree } \\
(1)\end{array}$ & b. Somewhat disagree & $\begin{array}{c}\text { c. Neither agree nor } \\
\text { disagree } \\
(3)\end{array}$ & $\begin{array}{c}\text { d. Somewhat agree } \\
\text { e. Strongly agree }\end{array}$ & (4) \\
\hline & $(2)$ & $29 \%$ & $\mathbf{4 4 \%}$ & $22 \%$ \\
\hline
\end{tabular}

Q46 GAP land-cover data are sufficiently current for my use. $(n=164$, average $=3)$

\begin{tabular}{|c|c|c|c|c|}
\hline $\begin{array}{l}\text { a. Strongly disagree } \\
\text { (1) }\end{array}$ & $\begin{array}{l}\text { b. Somewhat disagree } \\
\text { (2) }\end{array}$ & $\begin{array}{l}\text { c. Neither agree nor } \\
\text { disagree } \\
\text { (3) }\end{array}$ & $\begin{array}{l}\text { d. Somewhat agree } \\
\text { (4) }\end{array}$ & $\begin{array}{l}\text { e. Strongly agree } \\
\text { (5) }\end{array}$ \\
\hline $14 \%$ & $26 \%$ & $21 \%$ & $30 \%$ & $9 \%$ \\
\hline
\end{tabular}

Q47 The appropriate set of GAP land-cover data was available when I needed it. ( $n=164$, average $=4$ )

\begin{tabular}{|c|c|c|c|c|}
\hline a. Strongly disagree & b. Somewhat disagree & $\begin{array}{c}\text { c. Neither agree nor } \\
\text { disagree } \\
(3)\end{array}$ & $\begin{array}{c}\text { d. Somewhat agree } \\
\text { e. Strongly agree }\end{array}$ & $(5)$ \\
\hline$(1)$ & $(2)$ & $21 \%$ & $\mathbf{4 0 \%}$ & $19 \%$ \\
\hline
\end{tabular}

Q48 GAP land-cover data are the best available data. ( $n=165$, average $=3$ )

\begin{tabular}{|c|c|c|c|c|}
\hline $\begin{array}{l}\text { a. Strongly disagree } \\
\text { (1) }\end{array}$ & $\begin{array}{l}\text { b. Somewhat disagree } \\
\text { (2) }\end{array}$ & $\begin{array}{l}\text { c. Neither agree nor } \\
\text { disagree } \\
\text { (3) }\end{array}$ & $\begin{array}{c}\text { d. Somewhat agree } \\
\text { (4) }\end{array}$ & $\begin{array}{l}\text { e. Strongly agree } \\
\text { (5) }\end{array}$ \\
\hline $13 \%$ & $22 \%$ & $28 \%$ & $26 \%$ & $12 \%$ \\
\hline
\end{tabular}


Q49 GAP land-cover data are easy to use with other datasets. $(n=165$, average 4$)$

\begin{tabular}{|c|c|c|c|c|}
\hline $\begin{array}{l}\text { a. Strongly disagree } \\
\text { (1) }\end{array}$ & $\begin{array}{l}\text { b. Somewhat disagree } \\
\text { (2) }\end{array}$ & $\begin{array}{l}\text { c. Neither agree nor } \\
\text { disagree } \\
\text { (3) }\end{array}$ & $\begin{array}{l}\text { d. Somewhat agree } \\
\text { (4) }\end{array}$ & $\begin{array}{l}\text { e. Strongly agree } \\
\text { (5) }\end{array}$ \\
\hline $2 \%$ & $3 \%$ & $27 \%$ & $45 \%$ & $24 \%$ \\
\hline
\end{tabular}

Q50 GAP land-cover data are developed through cooperation with stakeholders (potential users of data). $(n=$ 163 , average $=4$ )

\begin{tabular}{|c|c|c|c|c|}
\hline a. Strongly disagree & $\begin{array}{c}\text { b. Somewhat disagree } \\
(1)\end{array}$ & $\begin{array}{c}\text { c. Neither agree nor } \\
\text { disagree } \\
(3)\end{array}$ & $\begin{array}{c}\text { d. Somewhat agree } \\
\text { e. Strongly agree }\end{array}$ & $(4)$ \\
\hline $1 \%$ & $3 \%$ & $\mathbf{4 4 \%}$ & $36 \%$ & $17 \%$ \\
\hline
\end{tabular}

Q51 It is easy for me to access the GAP land-cover data I need. $(n=165$, average $=4)$

\begin{tabular}{|c|c|c|c|c|}
\hline $\begin{array}{l}\text { a. Strongly disagree } \\
\text { (1) }\end{array}$ & $\begin{array}{l}\text { b. Somewhat disagree } \\
\text { (2) }\end{array}$ & $\begin{array}{l}\text { c. Neither agree nor } \\
\text { disagree } \\
\text { (3) }\end{array}$ & $\begin{array}{l}\text { d. Somewhat agree } \\
\text { (4) }\end{array}$ & $\begin{array}{c}\text { e. Strongly agree } \\
\text { (5) }\end{array}$ \\
\hline $1 \%$ & $3 \%$ & $19 \%$ & $39 \%$ & $38 \%$ \\
\hline
\end{tabular}

Q52 GAP land-cover data are sufficiently complete for my intended uses. $(n=163$, average $=3$ )

\begin{tabular}{|c|c|c|c|c|}
\hline $\begin{array}{c}\text { a. Strongly disagree } \\
\text { (1) }\end{array}$ & $\begin{array}{l}\text { b. Somewhat disagree } \\
\text { (2) }\end{array}$ & $\begin{array}{l}\text { c. Neither agree nor } \\
\text { disagree } \\
\text { (3) }\end{array}$ & $\begin{array}{c}\text { d. Somewhat agree } \\
\text { (4) }\end{array}$ & $\begin{array}{c}\text { e. Strongly agree } \\
\text { (5) }\end{array}$ \\
\hline $7 \%$ & $16 \%$ & $29 \%$ & $37 \%$ & $12 \%$ \\
\hline
\end{tabular}

Q53 At what level would you rate the quality of GAP land-cover data? $(n=162$, average $=3$ )

\begin{tabular}{|c|c|c|c|c|}
\hline $\begin{array}{c}\text { a. Very low } \\
(1)\end{array}$ & b. Low & $\begin{array}{c}\text { c. Medium } \\
\text { (3) }\end{array}$ & $\begin{array}{c}\text { d. High } \\
(4)\end{array}$ & $\begin{array}{c}\text { e. Very high } \\
(5)\end{array}$ \\
\hline $3 \%$ & $4 \%$ & $\mathbf{5 2 \%}$ & $39 \%$ & $3 \%$ \\
\hline
\end{tabular}

Q54 To what extent do GAP land-cover data meet your expectations? $(n=162$, average $=3)$

\begin{tabular}{|c|c|c|c|}
\hline $\begin{array}{c}\text { a. Not at all } \\
(1)\end{array}$ & $\begin{array}{c}\text { b. Meets some expectations } \\
(2)\end{array}$ & $\begin{array}{c}\text { c. Meets most expectations } \\
\mathbf{( 3 )}\end{array}$ & $\begin{array}{c}\text { d. Meets all expectations } \\
(4)\end{array}$ \\
\hline $6 \%$ & $38 \%$ & $\mathbf{5 5 \%}$ & $2 \%$ \\
\hline
\end{tabular}

Q55 In your opinion, what one type of information or feature could be added to GAP land-cover data to make the data more useful? [open-ended response] $(n=88)$

Several respondents made multiple comments. If a respondent made multiple comments, the comments were split into independent components before the responses were summarized.

\begin{tabular}{|l|}
\hline Response \\
\hline Theme: Update $(n=20)$ \\
\hline We need the dam thing updated for Arkansas! \\
\hline Updated for fire information \\
\hline The data should be more up-to-date. \\
\hline No new features - just a refresh with more current imagery. \\
\hline Needs updated \\
\hline Needs to be more current \\
\hline More up-to-date \\
\hline
\end{tabular}




\begin{tabular}{|c|}
\hline More recent data \\
\hline More frequent/current data \\
\hline More frequent updates \\
\hline Just update it every three years to include land cover changes \\
\hline It should be updated with cooperators' latest findings. \\
\hline It needs to be updated using current interpretive methodologies \\
\hline An update is needed. \\
\hline Accurate, up-to-date cover types \\
\hline A reliable refresh schedule for landcover updates. \\
\hline Not the content as much as the currentness. Iowa is almost 20 years old, based on satellite acquisition dates. \\
\hline Updated more regularly \\
\hline Updated frequency \\
\hline Regular 2-3 yr classifications with accuracy assessments per class. \\
\hline Theme: Change classification $(n=11)$ \\
\hline More LC categories \\
\hline More distance classes would be useful. \\
\hline Classification categories that are most linked to landscape integrity and water quality \\
\hline If we could distinguish between major deciduous forest types, that might be helpful with species modeling. \\
\hline Upland or lowland forest \\
\hline Higher level of classification \\
\hline $\begin{array}{l}\text { For Hawaii GAP, we created too many landcover classes which greatly reduced user accuracy. National } \\
\text { stewardship categories did not adequately reflect our local stewardship types. I now recommend LANDFIRE } \\
\text { because the landcover classes are clearly defined and consistent. }\end{array}$ \\
\hline Finer splits in vegetation cover \\
\hline $\begin{array}{l}\text { Relevant classes for climate research related to physiological functions of vegetation types rather than just } \\
\text { descriptive classification. }\end{array}$ \\
\hline $\begin{array}{l}\text { Improve integration of multiple classification units and scales (coarse-fine with NVC units; i.e., with new alliances, } \\
\text { 'mappable alliances' going finer, plus upper NVC hierarchy and Cowardin levels for wetlands)- see NatureServe } \\
\text { map attributes. }\end{array}$ \\
\hline Crosswalks to other/older vegetation classifications \\
\hline Theme: Verification $(n=9)$ \\
\hline More ground control \\
\hline More field checking \\
\hline Greater ground truthing, more precise \\
\hline Accuracy Assessments \\
\hline Accuracy assessment is needed. \\
\hline $\begin{array}{l}\text { Accuracy Assessment by state? or mapping zone. Overall accuracy is nice but if I am only using a state area, how } \\
\text { good is it there? This might be able to be done with some sort of volunteer accuracy assessment using points in } \\
\text { different states that are known. Some states are trying or are doing a network of known observation points for } \\
\text { classification or accuracy assessment work. }\end{array}$ \\
\hline Quality/accuracy assessment of the results \\
\hline More truthing of roads, vegetation and all layers. \\
\hline Accuracy assessment for the scale at which they are collected \\
\hline More ground control \\
\hline Theme: Add information $(n=9)$ \\
\hline Stand ages or seral stages \\
\hline Percent native plant cover \\
\hline
\end{tabular}




\begin{tabular}{|c|}
\hline More detailed land use data \\
\hline Landforms data \\
\hline More urban use categories \\
\hline Forest age. \\
\hline Utilities locations for pipeline, transmission lines, and other utility lines. \\
\hline I would like a canopy cover dataset \\
\hline Condition/Quality of the habitat \\
\hline Theme: Resolution $(n=7)$ \\
\hline Increased temporal resolution \\
\hline $\begin{array}{l}\text { Landcover for example is categorized well, however the best thing that could happen is to have more refined } \\
\text { resolution (somewhat coarse for many of our uses) }\end{array}$ \\
\hline Higher resolution \\
\hline Finer resolution \\
\hline Better resolution \\
\hline More spatial and thematic resolution \\
\hline GAP analysis derived from higher resolution imagery - LandSat resolution is not good enough for Pacific Islands. \\
\hline Theme: Improve accuracy $(n=6)$ \\
\hline Accurately classified \\
\hline Better accuracy \\
\hline Classification accuracy \\
\hline Improving accuracy and currency is more important than adding features. \\
\hline Need to refine accuracy of categories and provide info on how categories are selected and combined or overlapped. \\
\hline $\begin{array}{l}\text { Many folks use GAP data at a regional scale. In my case, we use GAP data for somewhat rare landcover types (e.g. } \\
\text { patches) in a regional context. GAP identifies that these patches are there, but it does a poor job identifying the } \\
\text { spatial extent and size of these cover types at the patch level (e.g. aspen patches in matrix of sagebrush). }\end{array}$ \\
\hline Theme: Ease of use $(n=6)$ \\
\hline Easy to download, seamless and easy to incorporate into GIS \\
\hline Easier ways to lump/split data \\
\hline Ease of use \\
\hline Easier format (geo-db, or shapefile not raster) \\
\hline Data needs to be scalable and allow for analysis at both fine and broader scales. \\
\hline Make clips available, to state boundaries with 1-mile or 3-mile buffer \\
\hline Theme: Wetlands $(n=4)$ \\
\hline Better wetlands cover \\
\hline Better wetland information \\
\hline Better riparian land cover \\
\hline Better information on wetlands and updated land cover \\
\hline Theme: Scale $(n=4)$ \\
\hline Use of larger spatial scale imagery such as RapidEye to create land cover maps \\
\hline Type is fine. Scale is the issue. NAIP is more useful to me. \\
\hline $\begin{array}{l}\text { It is all a matter of scale. At the State level GAP data is sufficient, to determine species habitat needs GAP data is } \\
\text { not sufficient. }\end{array}$ \\
\hline Raster cells of a finer scale \\
\hline Theme: Classification consistency $(n=4)$ \\
\hline Consistent cover types mapped across states/regions \\
\hline More consistent use of landcover types across regions. \\
\hline
\end{tabular}




\begin{tabular}{|c|}
\hline Consistency across borders \\
\hline Consistent classification across scenes \\
\hline Theme: Background information ( $n=4)$ \\
\hline Streamlined access to additional datasets that were used to compile the thematic layers. \\
\hline $\begin{array}{l}\text { Since the data are now provided as ecological systems, it would be nice to have the associated point data classified } \\
\text { to the NVC. Possibly this is available and I have not sought it out?? }\end{array}$ \\
\hline Brief summary of modeling methods for integrated datasets \\
\hline A source date for the land cover. \\
\hline Theme: Availability of error/accuracy information $(n=4)$ \\
\hline $\begin{array}{l}\text { Integration of error matrix attributes into the dataset for direct use as opposed to having to refer to separate Excel } \\
\text { spreadsheets by mapping zone }\end{array}$ \\
\hline Information about mapping accuracy for each land cover class in an easily accessible location \\
\hline $\begin{array}{l}\text { I extensively use land cover data to create ecosystem maps for the Coronado National Forest. In places I've visited, } \\
\text { sometimes the GAP data is on the money, and other times it's not close. Naturally, this has something to do with } \\
\text { whether a particular place has been field checked. SO! The GAP data would be more useful if there was a layer that } \\
\text { showed where the field team had visited, as well as the data they collected from the field. Then I could look at the } \\
\text { land cover data for a particular place and know if it has been field checked or if it is simply the output of a very } \\
\text { complicated algorithm. }\end{array}$ \\
\hline $\begin{array}{l}\text { Estimated error rates based on some kind of ground truthing or crowdsourced error checking. In some areas the data } \\
\text { is fairly unreliable, and it would be great just to have some error bars on the data. }\end{array}$ \\
\hline Theme: Structure $(n=3)$ \\
\hline Structure \\
\hline Structural data from lidar \\
\hline $\begin{array}{l}\text { Work with LANDFIRE to improve on vegetation structure (cover of non-woody and woody veg - need higher field- } \\
\text { sample density) as compliment to ecological system type }\end{array}$ \\
\hline Theme: No opinion $(n=3)$ \\
\hline $\begin{array}{l}\text { I'm putting an answer down for the next question, but you should know that I really have no idea; I don't really } \\
\text { know the GAP data or processes that well. }\end{array}$ \\
\hline I have no suggestions at this time. \\
\hline Don't have an opinion \\
\hline Theme: Smaller pixels $(n=2)$ \\
\hline Smaller pixel size \\
\hline Greater detail, smaller pixel resolution \\
\hline Theme: Change map $(n=2)$ \\
\hline A map of land cover change would be good. \\
\hline Changes over five years \\
\hline Theme: Agricultural classification ( $n=2)$ \\
\hline $\begin{array}{l}\text { I think the biggest accuracy issue overall for my area of interest is the misclassification of some tilled agriculture as } \\
\text { natural cover types and vice versa. Being able to distinguish tilled agriculture from irrigated hay meadows would } \\
\text { also be very helpful. }\end{array}$ \\
\hline Distinguish between different agricultural uses (e.g. tilled/grazed/mowed etc.) \\
\hline No theme: \\
\hline I am not aware of any reliable land cover Gap data for Texas. \\
\hline Having a landcover for Maryland would be useful. \\
\hline
\end{tabular}


Q56 Are there alternative sources for the information provided in GAP land-cover data - similar data but from a different source? $(n=167)$

\begin{tabular}{|l|c|}
\hline Response & Percent \\
\hline a. Yes & $\mathbf{7 4}$ \\
\hline b. No & 26 \\
\hline
\end{tabular}

If respondents indicated there were alternative sources in Q56, they were asked to name the primary alternative (Q57). If respondents answered "No" to Q56, they were directed next to Q58.

Q57 Name the primary alternative to GAP land-cover data. [open-ended response] ( $n=108)$

Several respondents named multiple alternative datasets. In those cases, each database named was listed separately before the responses were summarized.

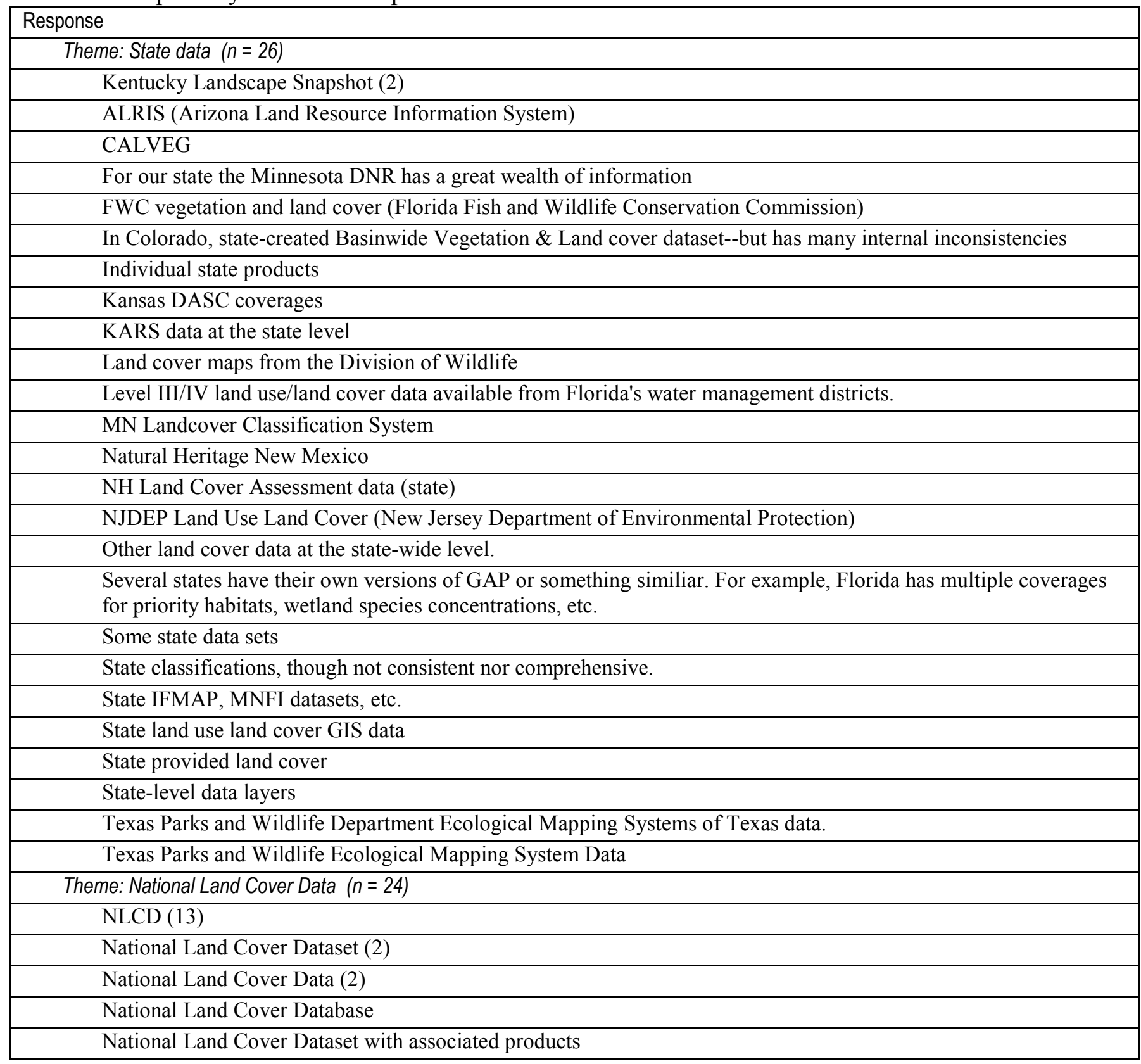




\begin{tabular}{|c|}
\hline National land cover is similar but different \\
\hline NLC database \\
\hline MRLC (Multi-Resolution Land Characteristics Consortium) \\
\hline NLCD at national levels \\
\hline NLCD, more current but categories aren't exactly the same. \\
\hline Theme: LANDFIRE $(n=21)$ \\
\hline Landfire (15) \\
\hline LandFire at national levels \\
\hline LANDFIRE EVT \\
\hline LANDFIRE Existing Vegetation Cover \\
\hline Landfire land cover \\
\hline LANDFIRE most commonly \\
\hline LANDFIRE, which includes GAP data but also includes other sources. \\
\hline Theme: Local data $(n=9)$ \\
\hline County or project level data could be used to make GAP better. \\
\hline Irregularly available county datasets \\
\hline Local contracted coverages \\
\hline Local land use and land cover \\
\hline Local vegetation data--limited to the land base managed by the unit \\
\hline Local/regional agency-created land cover maps \\
\hline NEAFWA habitat classification map \\
\hline Regional or county vegetation data \\
\hline Various local sources \\
\hline Theme: National Oceanic and Atmospheric Administration - Coastal Change Analysis Program (C-CAP) $(n=5)$ \\
\hline C-CAP (2) \\
\hline C-CAP data \\
\hline CCAP Landcover \\
\hline $\begin{array}{l}\text { NOAA C-CAP data provides land cover information, but does not include as much detail on the type of forest, } \\
\text { shrub, or grassland cover (i.e. native vs. non-native) as does GAP. }\end{array}$ \\
\hline Theme: Self-made data $(n=4)$ \\
\hline Acquisition of remote sensing or photography for areas of interest for local interpretation \\
\hline Generating our own refined data via remote sensing methodology \\
\hline Not as functional, but I use straight aerial imagery most often to get a better idea of coverage. \\
\hline Self-derived land cover data, typically from Landsat or ASTER. We do this only for small areas, not statewide. \\
\hline Theme: United States Department of Agriculture data $(n=4)$ \\
\hline FSA imagery (Farm Service Agency) \\
\hline USDA \\
\hline USDA agriculture data \\
\hline USDA Landcover data \\
\hline Theme: United States Forest Service data $(n=4)$ \\
\hline FIA LULC (Forest Inventory and Analysis) \\
\hline US Forest Service \\
\hline USFS Corporate Vegetation data \\
\hline $\begin{array}{l}\text { We once used some data from the Forest Service that as I recall was land cover. 5+ years ago, so I'm a bit fuzzy. I } \\
\text { don't know if the FS sends their data to our GAP office here in town, or not. }\end{array}$ \\
\hline Theme: National Park Service data $(n=3)$ \\
\hline
\end{tabular}




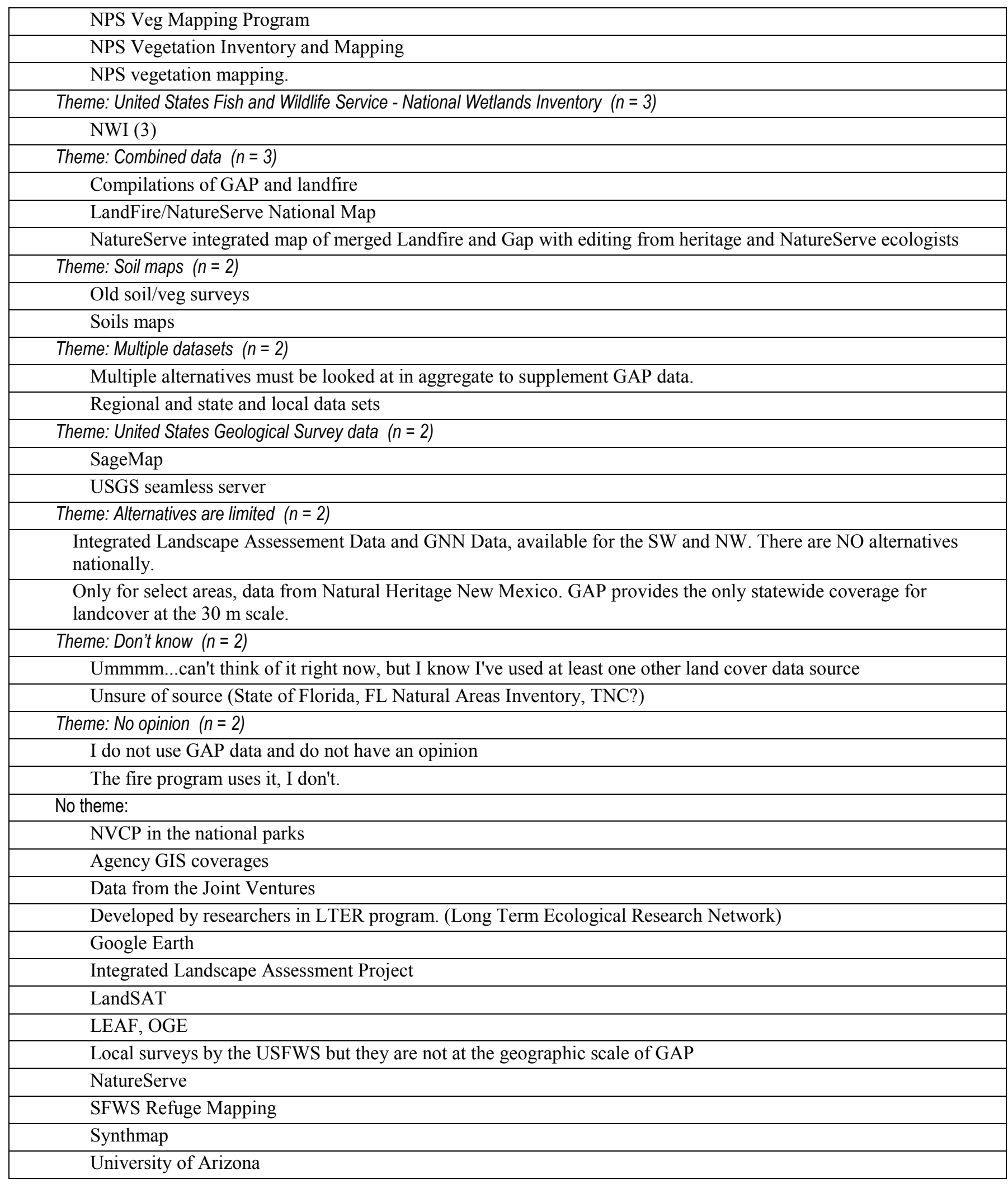


Q58 How would you grade the current performance of GAP on mapping the land cover of the United States? $(n=$ 107 , average $=3$ )

\begin{tabular}{|c|c|c|c|c|c|}
\hline a. A & b. B & c. C & d. D & e. F & $\begin{array}{c}\text { f. I don't have enough } \\
\text { knowledge to grade this item } \\
\text { (no value) }\end{array}$ \\
\hline$(4)$ & $(3)$ & $(2)$ & $(1)$ & $(0)$ & $35 \%$ \\
\hline $8 \%$ & $\mathbf{4 4 \%}$ & $12 \%$ & $2 \%$ & & \\
\hline
\end{tabular}
Q108.

The respondents who completed the questions regarding land-cover data were next directed to

\section{Predicted Species Distribution Data}

Q59 GAP predicted species distribution datasets are useful at the following levels (select all that apply). $(n=65)$

\begin{tabular}{|l|c|c|}
\hline Response & $\begin{array}{c}\text { Number of } \\
\text { times selected }\end{array}$ & Percent \\
\hline a. National & 31 & 48 \\
\hline b. Regional & 39 & 60 \\
\hline c. Ecosystem & 35 & 54 \\
\hline d. State & $\mathbf{5 1}$ & $\mathbf{7 8}$ \\
\hline e. County & 27 & 42 \\
\hline f. Refuge & 12 & 18 \\
\hline g. Other: [open-ended response] & 4 & 6 \\
\hline Watershed & & \\
\hline Regions with a state (i.e., multiple counties) & & \\
\hline Municipality & & \\
\hline Global & & \\
\hline
\end{tabular}

Q60 GAP predicted species distribution datasets are necessary at the following levels (select all that apply). ( $n=$ 64)

\begin{tabular}{|l|c|c|}
\hline Response & $\begin{array}{c}\text { Number of } \\
\text { times selected }\end{array}$ & Percent \\
\hline a. National & 37 & 58 \\
\hline b. Regional & 45 & 70 \\
\hline c. Ecosystem & 40 & 63 \\
\hline d. State & 47 & 73 \\
\hline e. County & 32 & 50 \\
\hline f. Refuge & 18 & 28 \\
\hline g. Other: [open-ended response] & 4 & 6 \\
\hline Watershed & & \\
\hline Municipality & & \\
\hline Global & & \\
\hline Depends on the taxa & & \\
\hline
\end{tabular}

Q61 How important is it to have consistent seamless national coverage of predicted species distribution data? ( $n$ $=65$, average $=4$ )

\begin{tabular}{|c|c|c|c|c|}
\hline $\begin{array}{c}\text { a. Not important } \\
(1)\end{array}$ & $\begin{array}{c}\text { b. Slightly important } \\
(2)\end{array}$ & $\begin{array}{c}\text { c. Important } \\
(3)\end{array}$ & $\begin{array}{c}\text { d. Very important } \\
(\mathbf{4})\end{array}$ & $\begin{array}{c}\text { e. Critical } \\
(5)\end{array}$ \\
\hline $5 \%$ & $11 \%$ & $25 \%$ & $\mathbf{3 9 \%}$ & $22 \%$ \\
\hline
\end{tabular}


Q62 How frequently should GAP predicted species distribution data be produced? $(n=64)$

\begin{tabular}{|l|c|}
\hline Response & Percent \\
\hline a. Yearly & 5 \\
\hline b. Every 2-4 years & 19 \\
\hline c. Every 5-7 years & $\mathbf{3 6}$ \\
\hline d. Every 8-10 years & $\mathbf{3 6}$ \\
\hline e. Other: [open-ended response] & 5 \\
\hline \multicolumn{2}{|l|}{ Occasionally } \\
\hline $\begin{array}{l}\text { In regions where there is significant change, every 2-3 years. In other areas, the frequency could } \\
\text { be longer. }\end{array}$ \\
\hline 10-15 y & \\
\hline
\end{tabular}

Q63 It is more useful to me for species to be modeled on biological range rather than along state boundaries. $(n=64$, average $=4)$

\begin{tabular}{|c|c|c|c|c|}
\hline $\begin{array}{c}\text { a. Strongly disagree } \\
(1)\end{array}$ & b. Somewhat disagree & $\begin{array}{c}\text { c. Neither agree nor } \\
\text { disagree } \\
(3)\end{array}$ & $\begin{array}{c}\text { d. Somewhat agree } \\
(4)\end{array}$ & e. Strongly agree \\
\hline $2 \%$ & $(2)$ & $11 \%$ & $20 \%$ & (5) \\
\hline
\end{tabular}

Q64 The select group of species modeled by GAP is appropriate for my use. $(n=63$, average $=4)$

\begin{tabular}{|c|c|c|c|c|}
\hline $\begin{array}{l}\text { a. Strongly disagree } \\
\text { (1) }\end{array}$ & $\begin{array}{c}\text { b. Somewhat disagree } \\
\text { (2) }\end{array}$ & $\begin{array}{l}\text { c. Neither agree nor } \\
\text { disagree } \\
\text { (3) }\end{array}$ & $\begin{array}{l}\text { d. Somewhat agree } \\
\text { (4) }\end{array}$ & $\begin{array}{l}\text { e. Strongly agree } \\
\text { (5) }\end{array}$ \\
\hline & $13 \%$ & $14 \%$ & $44 \%$ & $29 \%$ \\
\hline
\end{tabular}

Q65 For my purposes, GAP predicted species distribution data are relevant. ( $n=64$, average $=4$ )

\begin{tabular}{|c|c|c|c|c|}
\hline $\begin{array}{c}\text { a. Strongly disagree } \\
\text { (1) }\end{array}$ & b. Somewhat disagree & $\begin{array}{c}\text { c. Neither agree nor } \\
\text { disagree } \\
(3)\end{array}$ & $\begin{array}{c}\text { d. Somewhat agree } \\
(4)\end{array}$ & e. Strongly agree \\
\hline & $5 \%$ & $9 \%$ & $42 \%$ & (5) \\
\hline
\end{tabular}

Q66 I believe that GAP predicted species distribution data are reliable. Reliable data are accurate, complete, dependable, and consistent. ( $n=64$, average $=4$ )

\begin{tabular}{|c|c|c|c|c|}
\hline a. Strongly disagree & b. Somewhat disagree & $\begin{array}{c}\text { c. Neither agree nor } \\
\text { disagree } \\
(3)\end{array}$ & $\begin{array}{c}\text { d. Somewhat agree } \\
\text { e. Strongly agree }\end{array}$ & (4) \\
\hline$(1)$ & $(2)$ & $14 \%$ & $\mathbf{5 2 \%}$ & $13 \%$ \\
\hline
\end{tabular}

Q67 Appropriate processes were used to assemble GAP predicted species distribution data. $(n=64$, average $=4)$

\begin{tabular}{|c|c|c|c|c|}
\hline a. Strongly disagree & b. Somewhat disagree & $\begin{array}{c}\text { c. Neither agree nor } \\
\text { disagree } \\
(3)\end{array}$ & $\begin{array}{c}\text { d. Somewhat agree } \\
\text { e. Strongly agree }\end{array}$ & (4) \\
\hline $2 \%$ & $(2)$ & $20 \%$ & $\mathbf{4 1 \%}$ & $30 \%$ \\
\hline
\end{tabular}


Q68 GAP predicted species distribution data are sufficiently current for my use. ( $n=64$, average $=4)$

\begin{tabular}{|c|c|c|c|c|}
\hline $\begin{array}{l}\text { a. Strongly disagree } \\
\text { (1) }\end{array}$ & $\begin{array}{l}\text { b. Somewhat disagree } \\
\text { (2) }\end{array}$ & $\begin{array}{l}\text { c. Neither agree nor } \\
\text { disagree } \\
\text { (3) }\end{array}$ & $\begin{array}{l}\text { d. Somewhat agree } \\
\text { (4) }\end{array}$ & $\begin{array}{l}\text { e. Strongly agree } \\
\text { (5) }\end{array}$ \\
\hline $8 \%$ & $16 \%$ & $16 \%$ & $36 \%$ & $25 \%$ \\
\hline
\end{tabular}

Q69 The appropriate set of GAP predicted species distribution data was available when I needed it. $(n=54$, average $=4$ )

\begin{tabular}{|c|c|c|c|c|}
\hline $\begin{array}{c}\text { a. Strongly disagree } \\
(1)\end{array}$ & $\begin{array}{c}\text { b. Somewhat disagree } \\
(2)\end{array}$ & $\begin{array}{c}\text { c. Neither agree nor } \\
\text { disagree } \\
(3)\end{array}$ & $\begin{array}{c}\text { d. Somewhat agree } \\
\text { e. Strongly agree }\end{array}$ & (4) \\
\hline $3 \%$ & $11 \%$ & $17 \%$ & $\mathbf{3 6 \%}$ & $33 \%$ \\
\hline
\end{tabular}

Q70 GAP predicted species distribution data are the best available data. $(n=62$, average $=3$ )

\begin{tabular}{|c|c|c|c|c|}
\hline $\begin{array}{l}\text { a. Strongly disagree } \\
\text { (1) }\end{array}$ & $\begin{array}{l}\text { b. Somewhat disagree } \\
\text { (2) }\end{array}$ & $\begin{array}{l}\text { c. Neither agree nor } \\
\text { disagree } \\
\text { (3) }\end{array}$ & $\begin{array}{l}\text { d. Somewhat agree } \\
\text { (4) }\end{array}$ & $\begin{array}{l}\text { e. Strongly agree } \\
\text { (5) }\end{array}$ \\
\hline $11 \%$ & $10 \%$ & $21 \%$ & $37 \%$ & $21 \%$ \\
\hline
\end{tabular}

Q71 GAP predicted species distribution data are easy to use with other datasets. $(n=63$, average $=4)$

\begin{tabular}{|c|c|c|c|c|}
\hline $\begin{array}{l}\text { a. Strongly disagree } \\
\text { (1) }\end{array}$ & $\begin{array}{c}\text { b. Somewhat disagree } \\
\text { (2) }\end{array}$ & $\begin{array}{l}\text { c. Neither agree nor } \\
\text { disagree } \\
\text { (3) }\end{array}$ & $\begin{array}{l}\text { d. Somewhat agree } \\
\text { (4) }\end{array}$ & $\begin{array}{l}\text { e. Strongly agree } \\
\text { (5) }\end{array}$ \\
\hline & $5 \%$ & $27 \%$ & $49 \%$ & $19 \%$ \\
\hline
\end{tabular}

Q72 GAP predicted species distribution data are developed through cooperation with stakeholders (potential users of data). ( $n=64$, average $=4)$

\begin{tabular}{|c|c|c|c|c|}
\hline $\begin{array}{l}\text { a. Strongly disagree } \\
\text { (1) }\end{array}$ & $\begin{array}{c}\text { b. Somewhat disagree } \\
\text { (2) }\end{array}$ & $\begin{array}{l}\text { c. Neither agree nor } \\
\text { disagree } \\
\text { (3) }\end{array}$ & $\begin{array}{c}\text { d. Somewhat agree } \\
\text { (4) }\end{array}$ & $\begin{array}{c}\text { e. Strongly agree } \\
\text { (5) }\end{array}$ \\
\hline $2 \%$ & $6 \%$ & $30 \%$ & $28 \%$ & $34 \%$ \\
\hline
\end{tabular}

Q73 GAP has a biologically meaningful rationale for defining the species to be modeled. $(n=64$, average $=4)$

\begin{tabular}{|c|c|c|c|c|}
\hline $\begin{array}{l}\text { a. Strongly disagree } \\
\text { (1) }\end{array}$ & $\begin{array}{l}\text { b. Somewhat disagree } \\
\text { (2) }\end{array}$ & $\begin{array}{l}\text { c. Neither agree nor } \\
\text { disagree } \\
\text { (3) }\end{array}$ & $\begin{array}{l}\text { d. Somewhat agree } \\
\text { (4) }\end{array}$ & $\begin{array}{l}\text { e. Strongly agree } \\
\text { (5) }\end{array}$ \\
\hline $2 \%$ & $2 \%$ & $28 \%$ & $42 \%$ & $27 \%$ \\
\hline
\end{tabular}

Q74 It is easy for me to access the GAP predicted species distribution data I need. ( $n=64$, average $=4$ )

\begin{tabular}{|c|c|c|c|c|}
\hline $\begin{array}{l}\text { a. Strongly disagree } \\
\text { (1) }\end{array}$ & $\begin{array}{l}\text { b. Somewhat disagree } \\
\text { (2) }\end{array}$ & $\begin{array}{l}\text { c. Neither agree nor } \\
\text { disagree } \\
\text { (3) }\end{array}$ & $\begin{array}{l}\text { d. Somewhat agree } \\
\text { (4) }\end{array}$ & $\begin{array}{c}\text { e. Strongly agree } \\
\text { (5) }\end{array}$ \\
\hline $3 \%$ & $14 \%$ & $19 \%$ & $34 \%$ & $30 \%$ \\
\hline
\end{tabular}

Q75 GAP predicted species distribution data are sufficiently complete for my intended uses. ( $n=64$, average $=3$ )

\begin{tabular}{|c|c|c|c|c|}
\hline $\begin{array}{l}\text { a. Strongly disagree } \\
\text { (1) }\end{array}$ & $\begin{array}{l}\text { b. Somewhat disagree } \\
\text { (2) }\end{array}$ & $\begin{array}{l}\text { c. Neither agree nor } \\
\text { disagree } \\
\text { (3) }\end{array}$ & $\begin{array}{c}\text { d. Somewhat agree } \\
\text { (4) }\end{array}$ & $\begin{array}{l}\text { e. Strongly agree } \\
\text { (5) }\end{array}$ \\
\hline $9 \%$ & $16 \%$ & $20 \%$ & $36 \%$ & $19 \%$ \\
\hline
\end{tabular}


Q76 Previous GAP projects used deductive modeling — based on expert input on habitat associations-for predicted species distributions. The Northwest Regional GAP project added inductive modeling-based on species occurrences, climatic data input, and statistical algorithms. To what extent will this change from deductive to inductive modeling improve GAP predicted species modeling? $(n=63$, average $=2)$

\begin{tabular}{|c|c|c|c|c|}
\hline $\begin{array}{c}\text { a. No improvement } \\
(1)\end{array}$ & b. Slight improvement & $\begin{array}{c}\text { c. Moderate } \\
\text { improvement } \\
(3)\end{array}$ & $\begin{array}{c}\text { d. Great improvement } \\
\text { e. Cannot judge }\end{array}$ & (no value) \\
\hline $3 \%$ & $(2)$ & $24 \%$ & $21 \%$ & $\mathbf{4 6 \%}$ \\
\hline
\end{tabular}

Q77 The selection of species to be modeled should be based on: (check one) ( $n=63)$

\begin{tabular}{|l|c|}
\hline Response & Percent \\
\hline $\begin{array}{l}\text { a. A hierarchical spatial model with widely occurring species being mapped more coarsely and species } \\
\text { dependent on small habitat patches being mapped more finely }\end{array}$ & $\mathbf{3 3}$ \\
\hline b. The species that are known to be modeled well with the current modeling approach used by GAP & 6 \\
\hline c. The species that were previously identified as GAP species & 8 \\
\hline d. Species that can be used as indicator, umbrella or keystone species & 22 \\
\hline $\begin{array}{l}\text { e. Species that are most sensitive to biological stressors such as climate change, invasive species, and habitat } \\
\text { fragmentation }\end{array}$ & 13 \\
\hline f. Other: [open-ended response]. & \\
\hline Theme: All species $(n=4)$ & \\
\hline Use all, no selection & \\
\hline All species should be modeled. & \\
\hline All species & \\
\hline All species were modeled when feasible. It depends on goals. & \\
\hline No theme: & \\
\hline Too difficult to select just one. Species identified as important by management in key regions. & \\
\hline Species for which model demand is high & \\
\hline Based on the adequacy of occurrences & \\
\hline I can't answer this question & \\
\hline
\end{tabular}

Q78 At what level would you assess the quality of GAP predicted species distribution data? $(n=63$, average $=3)$

\begin{tabular}{|c|c|c|c|c|}
\hline $\begin{array}{c}\text { a. Very low } \\
(1)\end{array}$ & b. Low & c. Medium & d. High & $(4)$ \\
\hline & $(2)$ & $(3)$ & $41 \%$ & e. Very high \\
\hline & $11 \%$ & $\mathbf{4 4 \%}$ & $(5)$ \\
\hline
\end{tabular}

Q79 To what extent do GAP predicted species distribution data meet your expectations? $(n=64$, average $=3)$

\begin{tabular}{|c|c|c|c|}
\hline $\begin{array}{c}\text { a. Not at all } \\
(1)\end{array}$ & b. Meets some expectations & c. Meets most expectations & d. Meets all expectations \\
$(2)$ & $(3)$ & $\mathbf{5 8 \%}$ \\
\hline & $41 \%$ & $2 \%$ \\
\hline
\end{tabular}

Q80 In your opinion, what one type of information or feature could be added to GAP predicted species distribution data to make the data more useful? [open-ended response] $(n=36)$

Several respondents made multiple comments. If a respondent made multiple comments, the comments were split into independent components before the responses were summarized.

\section{Response \\ Theme: Add information $(n=9)$}




\begin{tabular}{|c|}
\hline Scenarios with climate change options such as used in Cal-Adapt protocol \\
\hline Museum records \\
\hline $\begin{array}{l}\text { Inundation of sea level rise at intervals of } .5 \mathrm{~m}, 1 \mathrm{~m}, 1.5 \mathrm{~m}, 2.0 \mathrm{~m} \text {; flood inundation models, predictive changes in } \\
\text { species ranges with climate change }\end{array}$ \\
\hline Incorporate Geology or soils in the predicted veg cover layer \\
\hline $\begin{array}{l}\text { In the modeling, have minimal key requirements for species. For example, digitized soil data is necessary for } \\
\text { accurate modeling of many fossorial species. }\end{array}$ \\
\hline Climate Change data \\
\hline $\begin{array}{l}\text { At some point, we need more than presence/absence. Predicted distribution of abudance, productivity, usage may be } \\
\text { needed. For instance, users want to know which area is more preferred/optimal and which area is marginal. }\end{array}$ \\
\hline An overlay with known points of occurrence is always instructive. \\
\hline Additional spatial covariates \\
\hline Theme: No opinion $(n=5)$ \\
\hline Not sure - modeling is a very complex process. \\
\hline Not sure \\
\hline No ideas at this time \\
\hline I don't know. \\
\hline Have not used recently enough to comment \\
\hline Theme: Verification $(n=4)$ \\
\hline $\begin{array}{l}\text { Where applicable, GAP's species distribution models could be verified with Heritage Program's "element } \\
\text { occurrence" datasets (or NatureServe's data) to check if occurrences confirm what the models predicted. }\end{array}$ \\
\hline $\begin{array}{l}\text { Make sure underlying data used to determine model is collected during the period when the underlying landcover } \\
\text { accurately defined the areas utilized by the species. Many species use ephemeral habitats and changes in landuse } \\
\text { and succession can drastically alter species distributions such that predicted models may place species in habitats } \\
\text { that no longer occur (e.g. early successional habitats). }\end{array}$ \\
\hline Field verification sample size \\
\hline Confirmed locality records \\
\hline Theme: Species distributions $(n=4)$ \\
\hline Species range through habitats \\
\hline $\begin{array}{l}\text { I think that the type of modeling does not adequately describe many species distributions and using statistical } \\
\text { approach that includes species occurrence data is an important step }\end{array}$ \\
\hline Ecological scale of species \\
\hline Distribution of species into the climatic regions. \\
\hline Theme: Continuous refinement $(n=3)$ \\
\hline Continuous refinement. \\
\hline $\begin{array}{l}\text { Sustained maintenance and updated information based on on-going data gathering and integration from multiple } \\
\text { sources }\end{array}$ \\
\hline $\begin{array}{l}\text { Continue to consult state biologists and other experts to obtain good GAP data and to review draft models. I realize } \\
\text { this has significant costs associated. }\end{array}$ \\
\hline Theme: Update $(n=2)$ \\
\hline Recent updates for California \\
\hline $\begin{array}{l}\text { GAP data for Iowa and the rest of the Midwest needs to be updated; } 1992 \text { landcover data is not reflective of current } \\
\text { reality and thus predictive models based upon that are outdated too. }\end{array}$ \\
\hline Theme: Source data $(n=2)$ \\
\hline Sources used \\
\hline Dig deeper for source data (current species range, etc.) rather than just rely on web. \\
\hline Theme: Improve accuracy $(n=2)$ \\
\hline
\end{tabular}




\begin{tabular}{|c|}
\hline Work with the state wildlife agency to determine if the models are accurate - we've improved them! \\
\hline The inclusion of SSURGO-level soil map units in updated models would improve model accuracy for some species. \\
\hline Theme: Fine scale $(n=2)$ \\
\hline Fine-scale models for some species in particular sites \\
\hline Fine scale modeling \\
\hline Theme: Ease of use $(n=2)$ \\
\hline Online mapping access \\
\hline Allow user to define extent (i.e., state, region, etc.) \\
\hline Theme: Availability of error/accuracy information $(n=2)$ \\
\hline $\begin{array}{l}\text { Some value of certainty that incorporates both the uncertainty of the underlying spatial information, and the species- } \\
\text { habitat relationships. "Best available" cannot substitute for quantifiable uncertainty when applying this information } \\
\text { to decision making. }\end{array}$ \\
\hline $\begin{array}{l}\text { Accuracy assessment for each model would be helpful. A simple evaluation of errors of omission and comission for } \\
\text { example using some observation data gathered from state wildlife agencies, natural heritage programs, or other } \\
\text { survey efforts such as BBS or eBird. }\end{array}$ \\
\hline No theme: \\
\hline $\begin{array}{l}\text { Moving towards point data and prediction grids, leave the deductive models apart (unless shown to be useful), add } \\
\text { metadata, link with GBIF }\end{array}$ \\
\hline $\begin{array}{l}\text { Most of my work pertains to quantitative habitat suitability modeling in estuaries. There is no Aquatic GAP } \\
\text { program for the marine environment that I am aware of. I model species abundances using zero inflated models. A } \\
\text { basic problem with modeling estuarine and/or coastal habitats is sediment mapping. I have worked with [name } \\
\text { deleted] who used dbSEABED data from USGS to map sediments on the West Florida shelf. This is a good use of } \\
\text { USGS datasets (although I am not sure they are considered GAP data). }\end{array}$ \\
\hline $\begin{array}{l}\text { I'm pretty concerned at the way this series of questions characterizes prior versions of GAP and the most current } \\
\text { version. I don't agree with the characterization. The most recent version suffers from severely pixelized predicted } \\
\text { distributions, to the extent of being of limited utility, in my opinion, and I've never thought it accurate to portray } \\
\text { distributions as a million little disjunct dots. Very strange product. }\end{array}$ \\
\hline Incorporation of existing data sets as optional add-on component \\
\hline Finer resolution \\
\hline
\end{tabular}

Q81 Are there alternative sources for the information provided in GAP predicted species distribution datasimilar data but from a different source? $(n=64)$

\begin{tabular}{|l|c|}
\hline Response & Percent \\
\hline a. Yes & 42 \\
\hline b. No & $\mathbf{5 8}$ \\
\hline
\end{tabular}

If respondents indicated there were alternative sources in Q81, they were asked to name the primary alternative $(\mathrm{Q} 82)$. If respondents answered "No" to Q81, they were directed next to Q83.

Q82 Name the primary alternative to GAP predicted species distribution data. [open-ended response] $(n=22)$

If a respondent made multiple comments, the comments were split into independent components before the responses were summarized.

\begin{tabular}{|l|}
\hline Response \\
\hline Theme: State $(n=4)$ \\
\hline State Wildlife Agency data \\
\hline State produced products \\
\hline State game and fish atlas data \\
\hline Specific research projects or state agencies sometimes model species distributions; this tends to occur at smaller \\
\hline
\end{tabular}




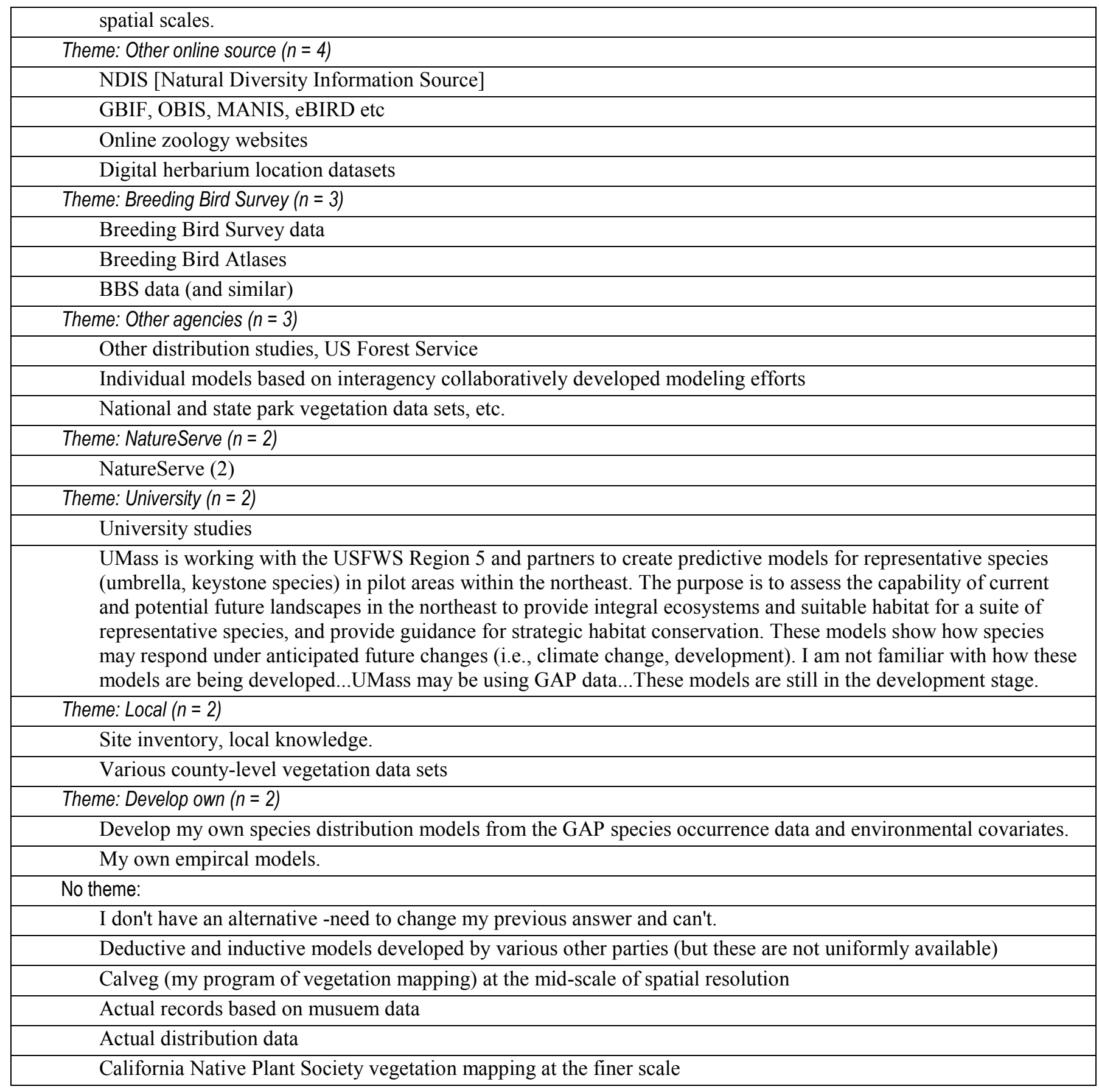

Q83 How would you grade the current performance of GAP on mapping the predicted distributions of vertebrate species for the United States? ( $n=64$, average $=3$ )

\begin{tabular}{|c|c|c|c|c|c|}
\hline a. A & b. B & c. C & d. D & (0) & $\begin{array}{l}\text { f. I don't have enough } \\
\text { knowledge to grade this } \\
\text { item } \\
\text { (no value) }\end{array}$ \\
\hline $13 \%$ & $38 \%$ & $8 \%$ & $3 \%$ & & $39 \%$ \\
\hline
\end{tabular}


The respondents who completed the questions regarding predicted species distribution data were next directed to Q108.

\section{Stewardship/Protected Areas Data}

Q84 GAP stewardship/protected areas datasets are useful at the following levels (select all that apply): $(n=28)$

\begin{tabular}{|l|c|c|}
\hline Response & $\begin{array}{c}\text { Number of } \\
\text { times selected }\end{array}$ & Percent \\
\hline a. National & 19 & 68 \\
\hline b. Regional & 18 & 64 \\
\hline c. Ecosystem & 17 & 61 \\
\hline d. State & $\mathbf{2 1}$ & $\mathbf{7 5}$ \\
\hline e. County & 13 & 46 \\
\hline f. Refuge & 2 & 7 \\
\hline g. Other: [open-ended response] & 5 & 18 \\
\hline HUC 8 Watershed & & \\
\hline Great Lakes & & \\
\hline Depends on application & & \\
\hline None, they are outdated. & & \\
\hline
\end{tabular}

\section{Q85 GAP stewardship/protected areas datasets are necessary at the following levels (select all that apply): $(n=$}

28)

\begin{tabular}{|l|c|c|}
\hline Response & $\begin{array}{c}\text { Number of } \\
\text { times selected }\end{array}$ & Percent \\
\hline a. National & 19 & 68 \\
\hline b. Regional & 17 & 61 \\
\hline c. Ecosystem & 16 & 57 \\
\hline d. State & $\mathbf{2 1}$ & $\mathbf{7 5}$ \\
\hline e. County & 18 & 64 \\
\hline f. Refuge & 3 & 11 \\
\hline g. Other: [open-ended response] & 4 & 14 \\
\hline HUC 8 Watershed & & \\
\hline Great Lakes & & \\
\hline Depends on application & \\
\hline
\end{tabular}

Q86 How important is it to have consistent seamless national coverage of stewardship/protected areas? $(n=29$, average $=4$ )

\begin{tabular}{|c|c|c|c|c|}
\hline $\begin{array}{c}\text { a. Not important } \\
(1)\end{array}$ & $\begin{array}{c}\text { b. Slightly important } \\
(2)\end{array}$ & $\begin{array}{c}\text { c. Important } \\
(3)\end{array}$ & $\begin{array}{c}\text { d. Very important } \\
(\mathbf{4})\end{array}$ & $\begin{array}{c}\text { e. Critical } \\
(5)\end{array}$ \\
\hline $3 \%$ & $10 \%$ & $21 \%$ & $\mathbf{3 5 \%}$ & $31 \%$ \\
\hline
\end{tabular}

Q87 How frequently should GAP stewardship/protected areas data be produced? $(n=29)$

\begin{tabular}{|l|c|}
\hline Response & Percent \\
\hline a. Yearly & 35 \\
\hline b. Every 2-4 years & $\mathbf{4 1}$ \\
\hline c. Every 5-7 years & 17 \\
\hline d. Every 8-10 years & \\
\hline
\end{tabular}




\begin{tabular}{|l|c|}
\hline e. Other: [open-ended response] & 7 \\
\hline Not Sure & \\
\hline Every 5 years in-line with national NLCD and census. & \\
\hline
\end{tabular}

Q88 Incorporating the United Nations Environment Programme's World Commission on Protected Areas IUCN (International Union for Conservation of Nature) codes is a great improvement. $(n=27$, average $=4)$

\begin{tabular}{|c|c|c|c|c|}
\hline $\begin{array}{l}\text { a. Strongly disagree } \\
\text { (1) }\end{array}$ & $\begin{array}{l}\text { b. Somewhat disagree } \\
\text { (2) }\end{array}$ & $\begin{array}{l}\text { c. Neither agree nor } \\
\text { disagree } \\
\text { (3) }\end{array}$ & $\begin{array}{l}\text { d. Somewhat agree } \\
\text { (4) }\end{array}$ & $\begin{array}{l}\text { e. Strongly agree } \\
\text { (5) }\end{array}$ \\
\hline $4 \%$ & $7 \%$ & $30 \%$ & $26 \%$ & $33 \%$ \\
\hline
\end{tabular}

Q89 For my purposes, GAP stewardship/protected areas data are relevant. ( $n=27$, average $=4$ )

\begin{tabular}{|c|c|c|c|c|}
\hline $\begin{array}{l}\text { a. Strongly disagree } \\
\text { (1) }\end{array}$ & $\begin{array}{l}\text { b. Somewhat disagree } \\
\text { (2) }\end{array}$ & $\begin{array}{l}\text { c. Neither agree nor } \\
\text { disagree } \\
\text { (3) }\end{array}$ & $\begin{array}{c}\text { d. Somewhat agree } \\
\text { (4) }\end{array}$ & $\begin{array}{l}\text { e. Strongly agree } \\
\text { (5) }\end{array}$ \\
\hline & & $19 \%$ & $26 \%$ & $56 \%$ \\
\hline
\end{tabular}

Q90 I believe that GAP stewardship/protected areas data are reliable. Reliable data are accurate, complete, dependable, and consistent. ( $n=27$, average $=4$ )

\begin{tabular}{|c|c|c|c|c|}
\hline a. Strongly disagree & b. Somewhat disagree & $\begin{array}{c}\text { c. Neither agree nor } \\
\text { disagree } \\
(3)\end{array}$ & $\begin{array}{c}\text { d. Somewhat agree } \\
\text { e. Strongly agree }\end{array}$ & (4) \\
\hline$(1)$ & $(2)$ & $26 \%$ & $\mathbf{3 7 \%}$ & $22 \%$ \\
\hline $4 \%$ & $11 \%$ & & $(5)$ \\
\hline
\end{tabular}

Q91 Appropriate processes were used to assemble GAP stewardship/protected areas data. $(n=27$, average $=4)$

\begin{tabular}{|c|c|c|c|c|}
\hline $\begin{array}{l}\text { a. Strongly disagree } \\
\text { (1) }\end{array}$ & $\begin{array}{l}\text { b. Somewhat disagree } \\
\text { (2) }\end{array}$ & $\begin{array}{l}\text { c. Neither agree nor } \\
\text { disagree } \\
\text { (3) }\end{array}$ & $\begin{array}{l}\text { d. Somewhat agree } \\
\text { (4) }\end{array}$ & $\begin{array}{l}\text { e. Strongly agree } \\
\text { (5) }\end{array}$ \\
\hline & & $26 \%$ & $41 \%$ & $33 \%$ \\
\hline
\end{tabular}

Q92 GAP stewardship/protected areas data are sufficiently current for my use. $(n=27$, average $=3$ )

\begin{tabular}{|c|c|c|c|c|}
\hline $\begin{array}{l}\text { a. Strongly disagree } \\
\text { (1) }\end{array}$ & $\begin{array}{l}\text { b. Somewhat disagree } \\
\text { (2) }\end{array}$ & $\begin{array}{l}\text { c. Neither agree nor } \\
\text { disagree } \\
\text { (3) }\end{array}$ & $\begin{array}{l}\text { d. Somewhat agree } \\
\text { (4) }\end{array}$ & $\begin{array}{l}\text { e. Strongly agree } \\
\text { (5) }\end{array}$ \\
\hline $11 \%$ & $15 \%$ & $19 \%$ & $30 \%$ & $26 \%$ \\
\hline
\end{tabular}

Q93 The appropriate set of GAP stewardship/protected areas data was available when I needed it. $(n=27$, average $=4$ )

\begin{tabular}{|c|c|c|c|c|}
\hline a. Strongly disagree & b. Somewhat disagree & $\begin{array}{c}\text { c. Neither agree nor } \\
\text { disagree } \\
(3)\end{array}$ & $\begin{array}{c}\text { d. Somewhat agree } \\
\text { e. Strongly agree }\end{array}$ & (4) \\
\hline $7 \%$ & $(2)$ & $19 \%$ & $\mathbf{3 3 \%}$ & $\mathbf{3 3 \%}$ \\
\hline
\end{tabular}

Q94 GAP stewardship/protected areas data are the best available data of that type. $(n=27$, average $=3$ )

\begin{tabular}{|c|c|c|c|c|}
\hline $\begin{array}{l}\text { a. Strongly disagree } \\
\text { (1) }\end{array}$ & $\begin{array}{l}\text { b. Somewhat disagree } \\
\text { (2) }\end{array}$ & $\begin{array}{l}\text { c. Neither agree nor } \\
\text { disagree } \\
\text { (3) }\end{array}$ & $\begin{array}{c}\text { d. Somewhat agree } \\
\text { (4) }\end{array}$ & $\begin{array}{l}\text { e. Strongly agree } \\
\text { (5) }\end{array}$ \\
\hline $11 \%$ & $11 \%$ & $41 \%$ & $15 \%$ & $22 \%$ \\
\hline
\end{tabular}


Q95 GAP stewardship/protected areas data are easy to use with other datasets. $(n=27$, average $=4)$

\begin{tabular}{|c|c|c|c|c|}
\hline $\begin{array}{l}\text { a. Strongly disagree } \\
\text { (1) }\end{array}$ & $\begin{array}{l}\text { b. Somewhat disagree } \\
\text { (2) }\end{array}$ & $\begin{array}{l}\text { c. Neither agree nor } \\
\text { disagree } \\
\text { (3) }\end{array}$ & $\begin{array}{l}\text { d. Somewhat agree } \\
\text { (4) }\end{array}$ & $\begin{array}{l}\text { e. Strongly agree } \\
\text { (5) }\end{array}$ \\
\hline $4 \%$ & & $22 \%$ & $33 \%$ & $41 \%$ \\
\hline
\end{tabular}

Q96 GAP stewardship/protected areas data are developed through cooperation with stakeholders (potential users of data). $(n=27$, average $=4)$

\begin{tabular}{|c|c|c|c|c|}
\hline a. Strongly disagree & b. Somewhat disagree & $\begin{array}{c}\text { c. Neither agree nor } \\
\text { disagree } \\
(3)\end{array}$ & $\begin{array}{c}\text { d. Somewhat agree } \\
\text { e. Strongly agree }\end{array}$ & (4) \\
\hline$(1)$ & $(2)$ & $22 \%$ & $\mathbf{4 4 \%}$ & $30 \%$ \\
\hline
\end{tabular}

Q97 It is easy for me to access the GAP stewardship/protected areas data I need. $(n=27$, average $=4)$

\begin{tabular}{|c|c|c|c|c|}
\hline $\begin{array}{l}\text { a. Strongly disagree } \\
\text { (1) }\end{array}$ & $\begin{array}{l}\text { b. Somewhat disagree } \\
\text { (2) }\end{array}$ & $\begin{array}{l}\text { c. Neither agree nor } \\
\text { disagree } \\
\text { (3) }\end{array}$ & $\begin{array}{c}\text { d. Somewhat agree } \\
\text { (4) }\end{array}$ & $\begin{array}{l}\text { e. Strongly agree } \\
\text { (5) }\end{array}$ \\
\hline $7 \%$ & & $19 \%$ & $30 \%$ & $44 \%$ \\
\hline
\end{tabular}

Q98 GAP stewardship/protected areas data are sufficiently complete for my intended uses. $(n=27$, average $=3$ )

\begin{tabular}{|c|c|c|c|c|}
\hline $\begin{array}{l}\text { a. Strongly disagree } \\
\text { (1) }\end{array}$ & $\begin{array}{l}\text { b. Somewhat disagree } \\
\text { (2) }\end{array}$ & $\begin{array}{c}\text { c. Neither agree nor } \\
\text { disagree } \\
\text { (3) }\end{array}$ & $\begin{array}{l}\text { d. Somewhat agree } \\
\text { (4) }\end{array}$ & $\begin{array}{c}\text { e. Strongly agree } \\
\text { (5) }\end{array}$ \\
\hline $7 \%$ & $22 \%$ & $19 \%$ & $26 \%$ & $26 \%$ \\
\hline
\end{tabular}

Q99 At what level would you assess the quality of GAP stewardship/protected areas data? $(n=27$, average $=3)$

\begin{tabular}{|c|c|c|c|c|}
\hline $\begin{array}{c}\text { a. Very low } \\
(1)\end{array}$ & $\begin{array}{c}\text { b. Low } \\
(2)\end{array}$ & $\begin{array}{c}\text { c. Medium } \\
(3)\end{array}$ & $\begin{array}{c}\text { d. High } \\
(4)\end{array}$ & $\begin{array}{c}\text { e. Very high } \\
(5)\end{array}$ \\
\hline $7 \%$ & $4 \%$ & $26 \%$ & $\mathbf{5 9 \%}$ & $4 \%$ \\
\hline
\end{tabular}

Q100 To what extent do GAP stewardship/protected areas data meet your expectations? $(n=27$, average $=3$ )

\begin{tabular}{|c|c|c|c|}
\hline $\begin{array}{c}\text { a. Not at all } \\
(1)\end{array}$ & b. Meets some expectations & $\begin{array}{c}\text { c. Meets most expectations } \\
(2)\end{array}$ & $\begin{array}{c}\text { d. Meets all expectations } \\
(4)\end{array}$ \\
\hline $7 \%$ & $30 \%$ & $\mathbf{4 8 \%}$ & $15 \%$ \\
\hline
\end{tabular}

Q101 In your opinion, what one type of information or feature could be added to GAP stewardship/protected areas data to make the data more useful? [open-ended response] $(n=13)$

Several respondents made multiple comments. If a respondent made multiple comments, the comments were split into independent components before the responses were summarized.

\begin{tabular}{|c|}
\hline Response \\
\hline Theme: Add information ( $n=4)$ \\
\hline Record level metadata showing time-sequenced annexations for each area. \\
\hline Measures of effectiveness (e.g., levels of impact inside vs. outside of PA) \\
\hline Biodiversity protection intent \\
\hline Links to source data \\
\hline Theme: Date information ( $n=3$ ) \\
\hline Year that land became protected \\
\hline Date of establishment (maybe you have added already) \\
\hline
\end{tabular}




\begin{tabular}{|l|}
\hline Data date for an individual record \\
\hline Theme: Update $(n=3)$ \\
\hline Up to date conservation easement data \\
\hline More frequent updates \\
\hline Update the data. \\
\hline Theme: Local data $(n=2)$ \\
\hline Local level data needs to be incorporated into the national dataset. \\
\hline Local (city, county, land trust) protected areas \\
\hline No theme: \\
\hline Tutorial about how to use GAP \\
\hline Increase consistency of local protected areas. \\
\hline Higher resolution \\
\hline $\begin{array}{l}\text { One consistent ranking scheme (e.g. gap status or IUCN, but some protected areas are still unranked. This makes it } \\
\text { difficult to use consistently at a national scale). }\end{array}$ \\
\hline
\end{tabular}

Q102 Are there alternative sources for the information provided in GAP stewardship/protected areas data — similar data but from a different source? $(n=28)$

\begin{tabular}{|l|c|}
\hline Response & Percent \\
\hline a. Yes & $\mathbf{7 5}$ \\
\hline b. No & 25 \\
\hline
\end{tabular}

If respondents indicated there were alternative sources in Q102, they were asked to name the primary alternative (Q103). If respondents answered "No" to Q102, they were directed next to Q104. If a respondent made multiple comments, the comments were split into independent components before the responses were summarized.

Q103 Name the primary alternative to GAP stewardship/protected areas data. [open-ended response] $(n=19)$

\begin{tabular}{|c|}
\hline Response \\
\hline Theme: State $(n=8)$ \\
\hline States \\
\hline State-created ownership data and/or individual agency datasets \\
\hline State maintained databases \\
\hline State Agency \\
\hline Individual state agencies and NGOs \\
\hline In VT Conserved Lands Database \\
\hline For Colorado there is COMaP which is better at the state level. \\
\hline Individual state by state databases (which are often updated more frequently). \\
\hline Theme: Non-Governmental Organization (NGO) ( $n=7)$ \\
\hline $\begin{array}{l}\text { Ducks Unlimited took Gap data and made it more current-- so I'd use that one, because Ohio's stewardship is } 10 \\
\text { years old (technology changes, parcels change) }\end{array}$ \\
\hline CBI's [Conservation Biology Institute] protected areas database \\
\hline $\begin{array}{l}\text { The Nature Conservancy's Boston Office assembles this data layer for use within TNC and I think provides this } \\
\text { layer to USGS. }\end{array}$ \\
\hline NGO data \\
\hline IUCN data on its own. \\
\hline http://conservationeasement.us/ \\
\hline
\end{tabular}




\begin{tabular}{|l|}
\hline WDPA [World Database on Protected Areas] \\
\hline Theme: Local $(n=2)$ \\
\hline Our own (Pima County) dataset. \\
\hline Local agency, county and LGU land records data \\
\hline Theme: Federal Agency $(n=7)$ \\
\hline NOAA C-CAP \\
\hline Federal agency data \\
\hline No theme: \\
\hline The data that I create as part of my job \\
\hline Strittholt's database \\
\hline Conservation partners. \\
\hline Managed Areas Database from UCSB. \\
\hline
\end{tabular}

Q104 How would you grade the current performance of GAP on documenting the representation of land ownership and protection (mapping stewardship/protected areas) in the United States? $(n=27)$

\begin{tabular}{|c|c|c|c|c|c|}
\hline a. A & b. B & C. C & d. D & e. F & $\begin{array}{c}\text { f. I don't have enough } \\
\text { knowledge to grade this } \\
\text { item } \\
\text { (no value) }\end{array}$ \\
\hline$(4)$ & $(3)$ & $(2)$ & $(1)$ & $(0)$ & $\mathbf{4 1 \%}$ \\
\hline
\end{tabular}

The respondents who completed the questions regarding stewardship/protected areas data were next directed to Q108.

Analysis Data

Q105 GAP analysis data, which combines land-cover, predicted species distribution, and stewardship/protected areas data, are sufficiently complete for my intended uses. $(n=32$, average $=3$ )

\begin{tabular}{|c|c|c|c|c|}
\hline $\begin{array}{c}\text { a. Strongly disagree } \\
(1)\end{array}$ & $\begin{array}{c}\text { b. Somewhat disagree } \\
(2)\end{array}$ & $\begin{array}{c}\text { c. Neither agree nor } \\
\text { disagree } \\
(3)\end{array}$ & $\begin{array}{c}\text { d. Somewhat agree } \\
\text { e. Strongly agree }\end{array}$ & (4) \\
\hline $6 \%$ & $22 \%$ & $28 \%$ & $\mathbf{4 1 \%}$ & $3 \%$ \\
\hline
\end{tabular}

Q106 Are there alternative sources for the information provided in GAP analysis data-similar data but from a different source? $(n=32)$

\begin{tabular}{|l|c|}
\hline Response & Percent \\
\hline a. Yes & $\mathbf{6 3}$ \\
\hline b. No & 38 \\
\hline
\end{tabular}

If respondents indicated there were alternative sources in Q106, they were asked to name the primary alternative (Q107). If respondents answered "No" to Q106, they were directed next to Q108. If a respondent made multiple comments, the comments were split into independent components before the responses were summarized.

Q107 Name the primary alternative to GAP analysis (land cover + predicted species + stewardship/protected areas) data. [open-ended response] $(n=17)$

Response

Theme: Multiple $(n=5)$ 


\begin{tabular}{|l|}
\hline $\begin{array}{l}\text { National Landcover Dataset; LandFIRE; Protected Areas Database; NatureServe species distributions; model-based } \\
\text { user-generated models of species occurrence and abundance }\end{array}$ \\
\hline National Fish Habitat Action plan NHDPlus, Regional projects \\
\hline Landfire for landcover, heritage programs for predicted species, state/NGOs for stewardship. \\
\hline Landscape Conservation Cooperative, Representative Species data sets \\
\hline CBI PAD, other land cover mapping (e.g., CCAP, NWI, region specific mapping like LCREP Lower Columbia \\
River mapping), other predicted species and/or critical habitat \\
\hline Theme: Landcover ( $n=3)$ \\
\hline This response only pertains to landcover data: NLCD and NOAA Coastal landcover data \\
\hline National Land Cover Database \\
\hline LANDFIRE, NLCD \\
\hline Theme: State ( $n=2$ ) \\
\hline State of Michigan data layers. \\
\hline State data sets \\
\hline Theme: University ( $n=2$ ) \\
\hline Individual research projects at a university \\
\hline Different research work done by universities using GIS. \\
\hline No theme: \\
\hline State and federal agencies GIS database \\
\hline Species range models \\
\hline Natural Heritage Data Base \\
\hline In-house data and analysis \\
\hline Expert elicitation (BBN) or nation-wide survey data (BBS). \\
\hline
\end{tabular}

\section{Benefits of Using GAP Data}

Q108 I intend to continue to use existing GAP data. ( $n=289$, average $=4$ )

\begin{tabular}{|c|c|c|c|c|}
\hline a. Strongly disagree & b. Somewhat disagree & $\begin{array}{c}\text { c. Neither agree nor } \\
\text { disagree } \\
(3)\end{array}$ & $\begin{array}{c}\text { d. Somewhat agree } \\
\text { e. Strongly agree }\end{array}$ & $(4)$ \\
\hline$(1)$ & $(2)$ & $17 \%$ & $31 \%$ & $\mathbf{( 5 )}$ \\
\hline $8 \%$ & $6 \%$ & $\mathbf{3 8 \%}$ \\
\hline
\end{tabular}

\section{Q109 To what extent are GAP data compatible with other datasets that you use? $(n=291$, average $=3$ )}

\begin{tabular}{|c|c|c|c|}
\hline $\begin{array}{c}\text { a. Not at all compatible } \\
(1)\end{array}$ & $\begin{array}{c}\text { b. Somewhat compatible } \\
(2)\end{array}$ & $\begin{array}{c}\text { c. Moderately compatible } \\
(3)\end{array}$ & $\begin{array}{c}\text { d. Very compatible } \\
\text { (4) }\end{array}$ \\
\hline $1 \%$ & $32 \%$ & $\mathbf{3 3 \%}$ & $\mathbf{3 3 \%}$ \\
\hline
\end{tabular}

If respondents indicated that GAP data were not compatible, they were next directed to Q110 for a follow-up question. If respondents indicated that GAP data were compatible with other data to any degree, they were directed to Q111. 
Q110 In what way are GAP data not compatible? $(n=4)$

\begin{tabular}{|l|c|}
\hline Response & Percent \\
\hline a. Resolution & $\mathbf{5 0}$ \\
\hline b. Format & \\
\hline c. Content & \\
\hline d. Software incompatibility & 50 \\
\hline e. Other: [open-ended response] & \\
\hline \multicolumn{1}{|c|}{ I used it for a past job. } & \\
\hline \multicolumn{1}{|c|}{ I do not use GAP data and do not have an opinion } & \\
\hline
\end{tabular}

Q111 To what extent does using GAP data improve your capacity to impact conservation of biodiversity? $(n=289)$

\begin{tabular}{|l|c|}
\hline Response & Percent \\
\hline a. I don't work directly on conservation of biodiversity & 16 \\
\hline b. Not at all & 2 \\
\hline c. Somewhat & 18 \\
\hline d. Moderately & 28 \\
\hline e. Substantially & $\mathbf{3 0}$ \\
\hline f. Use of GAP data maximizes my capacity. & 5 \\
\hline
\end{tabular}

Q112 Use of GAP data helps my organization achieve its conservation related goals. $(n=287$, average $=4)$

\begin{tabular}{|c|c|c|c|c|c|}
\hline $\begin{array}{c}\text { My organization } \\
\text { doesn't have } \\
\text { conservation } \\
\text { related goals } \\
\text { (no value) }\end{array}$ & a. Strongly disagree & $\begin{array}{c}\text { b. Somewhat } \\
\text { disagree }\end{array}$ & $\begin{array}{c}\text { c. Neither agree nor } \\
\text { disagree }\end{array}$ & d. Somewhat agree & e. Strongly agree \\
\hline $8 \%$ & $(1)$ & $(2)$ & $(3)$ & $(4)$ & $(5)$ \\
\hline
\end{tabular}

Q113 To what extent has use of GAP data improved your communication of information to others involved in conservation of biodiversity? ( $n=284$, average $=3$ )

\begin{tabular}{|c|c|c|c|}
\hline $\begin{array}{c}\text { a. Not at all } \\
(1)\end{array}$ & $\begin{array}{c}\text { b. Somewhat } \\
(2)\end{array}$ & $\begin{array}{c}\text { c. Moderately } \\
\text { (3) }\end{array}$ & $\begin{array}{c}\text { d. Substantially } \\
(4)\end{array}$ \\
\hline $12 \%$ & $30 \%$ & $\mathbf{3 4 \%}$ & $25 \%$ \\
\hline
\end{tabular}

Q114 To what extent does/did use of GAP data increase your productivity? $(n=284$, average $=3$ )

\begin{tabular}{|c|c|c|c|c|}
\hline $\begin{array}{c}\text { a. No increase in } \\
\text { productivity }\end{array}$ & $\begin{array}{c}\text { b. Slight increase in } \\
\text { productivity }\end{array}$ & $\begin{array}{c}\text { c. Moderate increase in } \\
\text { productivity }\end{array}$ & $\begin{array}{c}\text { d. Large increase in } \\
\text { productivity }\end{array}$ & $\begin{array}{c}\text { e. Extreme increase in } \\
\text { productivity }\end{array}$ \\
\hline$(1)$ & $(2)$ & $(3)$ & $(4)$ & $(5)$ \\
\hline $16 \%$ & $20 \%$ & $\mathbf{3 9 \%}$ & $22 \%$ & $3 \%$ \\
\hline
\end{tabular}

Q115 By using GAP data did your organization experience any of the following benefits?

\begin{tabular}{|l|c|c|}
\hline Benefits: & Percent Yes & Percent No \\
\hline $\begin{array}{l}\text { a. By using GAP data did your organization experience monetary savings? } \\
(n=277)\end{array}$ & 49 & $\mathbf{5 1}$ \\
\hline $\begin{array}{l}\text { b. By using GAP data did your organization experience time savings? } \\
(n=276)\end{array}$ & $\mathbf{6 9}$ & 31 \\
\hline $\begin{array}{l}\text { c. By using GAP data did your organization experience improved efficiency in the work process? } \\
(n=277)\end{array}$ & $\mathbf{7 1}$ & 29 \\
\hline
\end{tabular}




\begin{tabular}{|c|c|c|}
\hline $\begin{array}{l}\text { d. By using GAP data did your organization experience improved effectiveness? } \\
(n=275)\end{array}$ & 77 & 23 \\
\hline $\begin{array}{l}\text { e. By using GAP data did your organization experience improved decisions? } \\
(n=289)\end{array}$ & 72 & 28 \\
\hline \multicolumn{3}{|c|}{$\begin{array}{l}\text { f. If there are benefits, other than the ones named above, that your organization experienced as the result of using GAP data, please } \\
\text { name them here. [open-ended response] }(n=58)\end{array}$} \\
\hline \multicolumn{3}{|c|}{ Theme: Description of how GAP data were used $(n=8)$} \\
\hline \multicolumn{3}{|c|}{ GAP data were used in all phases of the resource management planning document. } \\
\hline \multicolumn{3}{|c|}{ GAP data was included in our State Wildlife Action Plan to provide a baseline of data. } \\
\hline \multicolumn{3}{|c|}{ Computing the amount of forest nationwide } \\
\hline \multicolumn{3}{|c|}{$\begin{array}{l}\text { Using landcover as color maps to drive 3D ecosystem placement/growth as accurately as possible given the } \\
\text { relatively coarse resolution it is provided as. }\end{array}$} \\
\hline \multicolumn{3}{|c|}{ Some states used GAP date in wildlife action plans. Helped them select and map habitat priorities for conservation. } \\
\hline \multicolumn{3}{|c|}{$\begin{array}{l}\text { We incorporated GAP data into our HabiMap Arizona conservation planning tool. Many of these questions are } \\
\text { hard to answer but this tool has the potential to dramatically change land use planning in AZ }\end{array}$} \\
\hline \multicolumn{3}{|c|}{$\begin{array}{l}\text { It adds to the Commonwealth's spatial data infrastructure. A "must" layer in a state with over } 90 \% \text { of land in } \\
\text { private hands... }\end{array}$} \\
\hline \multicolumn{3}{|c|}{$\begin{array}{l}\text { GAP data really help us understand land-use change at the County scale. No other products helped us the way GAP } \\
\text { has }\end{array}$} \\
\hline \multicolumn{3}{|c|}{ Theme: Not using GAP now $(n=7)$} \\
\hline \multicolumn{3}{|c|}{ Since I am not involved with use of GAP data at this moment, I can't answer the above questions. } \\
\hline \multicolumn{3}{|c|}{ Not using GAP data at this moment. } \\
\hline \multicolumn{3}{|l|}{ It's been like 5-8 years since I've used these data } \\
\hline \multicolumn{3}{|l|}{ I don't think we are using GAP } \\
\hline \multicolumn{3}{|c|}{ We haven't used GAP data, plan to use it if it fits our accuracy standards. } \\
\hline \multicolumn{3}{|c|}{ Since current GAP data were not available for the Northeast our organization sought other data sources. } \\
\hline \multicolumn{3}{|c|}{$\begin{array}{l}\text { Clark County is using its own current (2011) Vegetation data layer but could use an updated version in a couple of } \\
\text { years from now }\end{array}$} \\
\hline \multicolumn{3}{|c|}{ Theme: Useful in education $(n=4)$} \\
\hline \multicolumn{3}{|l|}{ Useful in an educational setting for conservation biology } \\
\hline \multicolumn{3}{|l|}{ Improved educational value to the public } \\
\hline \multicolumn{3}{|l|}{ Good teaching resource. } \\
\hline \multicolumn{3}{|c|}{ We use this dataset to teach GIS - it is an example of how much data/insight can come from one shapefile. } \\
\hline \multicolumn{3}{|c|}{ Theme: Credibility $(n=4)$} \\
\hline \multicolumn{3}{|l|}{ Improved the authoritativeness of the conclusions } \\
\hline \multicolumn{3}{|c|}{ Authoritative data sets improve the credibility of products } \\
\hline \multicolumn{3}{|c|}{$\begin{array}{l}\text { Citing a USGS project provides validation when using this data in certain regional-local green infrastructure or } \\
\text { regional planning projects. }\end{array}$} \\
\hline \multicolumn{3}{|c|}{ When two datasets agree, such as GAP and LandFire, it increases my confidence. } \\
\hline \multicolumn{3}{|c|}{ Theme: Communication $(n=4)$} \\
\hline Improved communication with the public. & & \\
\hline Communication of complexity & & \\
\hline Greatly improved communication with partners & & \\
\hline Overall understanding of and ability to communicate statewide $\mathrm{v}$ & & \\
\hline Theme: Don't know $(n=4)$ & & \\
\hline Unknown & & \\
\hline I would have preferred to not answer the last question about "im & use t & no way to \\
\hline
\end{tabular}




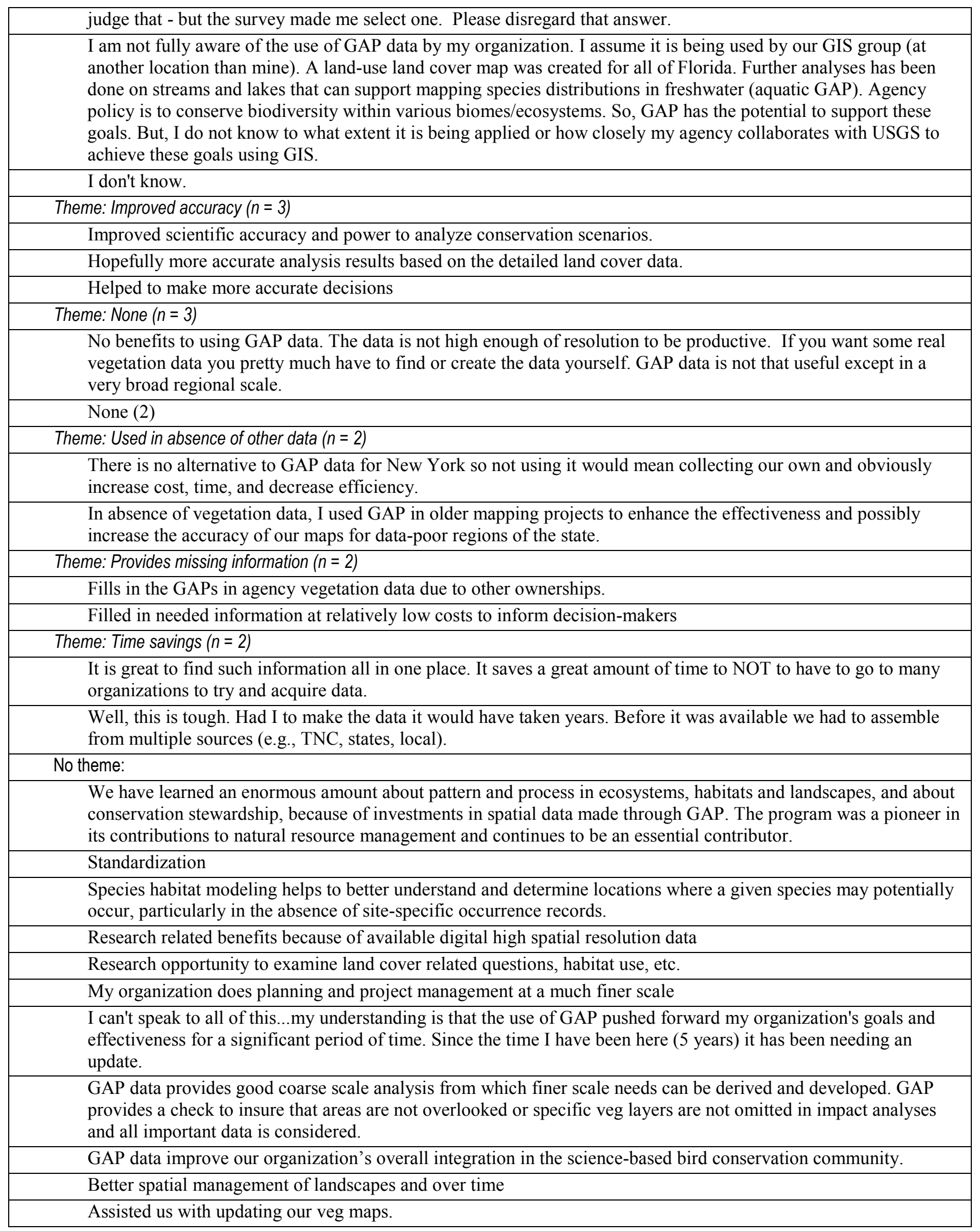




\begin{tabular}{|l|}
\hline Ability to identify potential partners to collaborate with on other projects in regions of interest. \\
\hline Ability to better work at regional scales \\
\hline $\begin{array}{l}\text { A current landcover dataset is necessary for what I routinely do. If one is not available, I must rely on one that is } \\
\text { out of date or not completely appropriate for my purposes (which leads to inaccuracy in my work). }\end{array}$ \\
\hline Used by other organizations that we work with \\
\hline
\end{tabular}

If the response to Q115e (Improved decisions) was "Yes," then the respondent was asked a follow-up question regarding the improved decisionmaking (Q116).

\section{Q116 In what way(s) did use of GAP data improve decisionmaking?}

\begin{tabular}{|c|c|c|}
\hline & Percent Yes & Percent No \\
\hline $\begin{array}{l}\text { a. Provided necessary information } \\
(n=201)\end{array}$ & 98 & 2 \\
\hline $\begin{array}{l}\text { b. Reduced uncertainty about decision options } \\
(n=198)\end{array}$ & 77 & 23 \\
\hline $\begin{array}{l}\text { c. Products based on GAP data allowed for better visualization of decision options } \\
(n=201)\end{array}$ & 93 & 7 \\
\hline $\begin{array}{l}\text { d. Products based on GAP data allowed for identification of issues that were unforeseen at the } \\
\text { beginning of the project } \\
(n=196)\end{array}$ & 62 & 38 \\
\hline \multicolumn{3}{|l|}{ e. Other ways in which use of GAP data improved decisionmaking. [open-ended response] ( $n=21)$} \\
\hline \multicolumn{3}{|l|}{ Theme: Communication $(n=2)$} \\
\hline \multicolumn{3}{|l|}{ Facilitated cross agency communication } \\
\hline \multicolumn{3}{|l|}{ Communication, triggering new science and open access work + data discussions } \\
\hline \multicolumn{3}{|l|}{ Theme: Don't know $(n=2)$} \\
\hline \multicolumn{3}{|l|}{ No others that I can think of at this moment } \\
\hline \multicolumn{3}{|l|}{ I don't know } \\
\hline \multicolumn{3}{|l|}{ Theme: None $(n=2)$} \\
\hline \multicolumn{3}{|l|}{ None (2) } \\
\hline \multicolumn{3}{|l|}{ No theme: } \\
\hline \multicolumn{3}{|l|}{ Wall to wall coverage } \\
\hline \multicolumn{3}{|c|}{ Used species models for many species to look at biodiversity and choose among land use decisions } \\
\hline \multicolumn{3}{|c|}{$\begin{array}{l}\text { Products, often in combination, provide key insights for investment in field data collection, making that costly } \\
\text { enterprise far more targeted and efficient. }\end{array}$} \\
\hline \multicolumn{3}{|c|}{ Of course the GAP products do all of the above } \\
\hline \multicolumn{3}{|c|}{ Identification of specific gaps in detailed data. } \\
\hline \multicolumn{3}{|c|}{ Helped to identify areas of potential conservation significance when site-specific data were lacking. } \\
\hline \multicolumn{3}{|c|}{ Has provided a check for some estimates about surrounding lands } \\
\hline \multicolumn{3}{|l|}{ For conservation target areas } \\
\hline \multicolumn{3}{|l|}{ Everyone has access to it so it can be independently analyzed. } \\
\hline \multicolumn{3}{|l|}{ Drives 2D information into 3 dimensional representations } \\
\hline \multicolumn{3}{|l|}{ Collaboration with land managers who do not maintain land cover inventory } \\
\hline \multicolumn{3}{|l|}{ Can facilitate more strategic decisions. } \\
\hline \multicolumn{3}{|c|}{$\begin{array}{l}\text { Assess value of surrogate species, validate expert-based models, link objectives and alternatives to estimate } \\
\text { consequences of management. }\end{array}$} \\
\hline \multicolumn{3}{|c|}{ Allowed quantification of land cover } \\
\hline Identified areas for additional landcover delineation & & \\
\hline
\end{tabular}


Q117 The work of my organization would suffer if GAP data were no longer available. $(n=282$, average $=4)$

\begin{tabular}{|c|c|c|c|c|}
\hline $\begin{array}{l}\text { a. Strongly disagree } \\
\text { (1) }\end{array}$ & $\begin{array}{l}\text { b. Somewhat disagree } \\
\text { (2) }\end{array}$ & $\begin{array}{l}\text { c. Neither agree nor } \\
\text { disagree } \\
\text { (3) }\end{array}$ & $\begin{array}{l}\text { d. Somewhat agree } \\
\text { (4) }\end{array}$ & $\begin{array}{c}\text { e. Strongly agree } \\
\text { (5) }\end{array}$ \\
\hline $6 \%$ & $10 \%$ & $27 \%$ & $33 \%$ & $25 \%$ \\
\hline
\end{tabular}

\section{Q118 If GAP data were no longer available, which of the following actions would your organization most likely} take? $(n=281)$

\begin{tabular}{|c|c|}
\hline Response & Percent \\
\hline a. I could switch to a readily available substitute dataset. & 18 \\
\hline b. I would have to search for an acceptable replacement dataset. & 48 \\
\hline c. Create the dataset ourselves & 25 \\
\hline d. Other: [open-ended response] & 8 \\
\hline \multicolumn{2}{|l|}{ Theme: Not an issue $(n=4)$} \\
\hline \multicolumn{2}{|l|}{ Not used in my current postion. } \\
\hline \multicolumn{2}{|l|}{ Not mission critical at present } \\
\hline \multicolumn{2}{|l|}{ No longer at an organization that requires GAP data } \\
\hline \multicolumn{2}{|l|}{ It would not affect us as we don't use GAP data } \\
\hline \multicolumn{2}{|l|}{ Theme: All of the above actions $(n=3)$} \\
\hline \multicolumn{2}{|l|}{ Some combination of all three above } \\
\hline \multicolumn{2}{|l|}{ Likely all three here... } \\
\hline \multicolumn{2}{|l|}{ Combination of above, with a lot of massaging of data } \\
\hline \multicolumn{2}{|l|}{ Theme: State data $(n=2)$} \\
\hline \multicolumn{2}{|l|}{ MN DNR } \\
\hline \multicolumn{2}{|l|}{ COMaP for Colorado but hosed outside of state boundaries } \\
\hline \multicolumn{2}{|l|}{ No theme: } \\
\hline \multicolumn{2}{|l|}{$\begin{array}{l}\text { We most likely just would do it as much as I might like to create the data set ourselves. The } \\
\text { reality is that it most likely wouldn't happen }\end{array}$} \\
\hline \multicolumn{2}{|l|}{ We already have our own dataset } \\
\hline \multicolumn{2}{|l|}{ Use air photos and common sense } \\
\hline \multicolumn{2}{|l|}{ USDA } \\
\hline \multicolumn{2}{|l|}{ Search for or create a dataset myself } \\
\hline \multicolumn{2}{|l|}{ Re-do datasets } \\
\hline \multicolumn{2}{|l|}{ Not sure } \\
\hline \multicolumn{2}{|l|}{ ND GAP land cover is out of date, would be useful to have current land cover data } \\
\hline \multicolumn{2}{|l|}{ If we couldn't afford to create the data set, we might just not have data we need to be effective. } \\
\hline \multicolumn{2}{|l|}{ I would have to search for/use multiple data sets } \\
\hline Continue to work locally and regionally for needed information & \\
\hline Already have and are creating and looking for ther sources of data & \\
\hline
\end{tabular}

Q119 If GAP data were no longer available, how much would you have to pay to purchase a substitute dataset? $(n=276)$

\begin{tabular}{|l|c|}
\hline Response & Percent \\
\hline a. Less than $\$ 10,000$ & 25 \\
\hline b. $\$ 10,000-20,000$ & 2 \\
\hline
\end{tabular}




\begin{tabular}{|l|c|}
\hline c. $\$ 20,001-50,000$ & 1 \\
\hline d. $\$ 50,001-100,000$ & 3 \\
\hline e. More than $\$ 100,000$ & 6 \\
\hline f. Unknown - no readily available substitute & $\mathbf{6 2}$ \\
\hline
\end{tabular}

Q120 If GAP data were not available and you had to use alternate data, how much less effective would your products be that you now base on GAP data? $(n=270$, average $=3$ )

\begin{tabular}{|c|c|c|c|c|}
\hline $\begin{array}{c}\text { a. Actually, the products } \\
\text { would be more effective } \\
(1)\end{array}$ & $\begin{array}{c}\text { b. No change in } \\
\text { effectiveness } \\
(2)\end{array}$ & $\begin{array}{c}\text { c. Somewhat less } \\
\text { effective } \\
(3)\end{array}$ & $\begin{array}{c}\text { d. Moderately less } \\
\text { effective } \\
(4)\end{array}$ & $\begin{array}{c}\text { e. Substantially less } \\
\text { effective } \\
(5)\end{array}$ \\
\hline $4 \%$ & $22 \%$ & $\mathbf{2 6 \%}$ & $24 \%$ & $24 \%$ \\
\hline
\end{tabular}

\section{GIS Software and Data Preferences}

Q121 Which GIS software packages do you frequently use? (Select all that apply.) $(n=276)$

When respondents named multiple software packages in the open-ended response option, each software package was counted separately in summarizing the responses.

\begin{tabular}{|c|c|c|}
\hline Response & $\begin{array}{l}\text { Number of } \\
\text { times selected }\end{array}$ & Percent \\
\hline a. ArcView & 97 & 35 \\
\hline b. ArcGIS & 245 & 89 \\
\hline c. Imagine & 33 & 12 \\
\hline d. GRASS & 6 & 2 \\
\hline e. ENVI & 15 & 5 \\
\hline f. Maplnfo & 6 & 2 \\
\hline g. Manifold & 2 & 1 \\
\hline h. Idrisi & 5 & 2 \\
\hline i. Other: [open-ended response] & 22 & 8 \\
\hline \multicolumn{3}{|l|}{ Theme: Quantum GIS $(n=9)$} \\
\hline \multicolumn{3}{|l|}{ Quantum GIS (5) } \\
\hline \multicolumn{3}{|l|}{ QGIS (3) } \\
\hline \multicolumn{3}{|l|}{ None - trying QGIS } \\
\hline \multicolumn{3}{|l|}{ Theme: $R(n=3)$} \\
\hline \multicolumn{3}{|l|}{$\mathrm{R}$} \\
\hline \multicolumn{3}{|l|}{ R (spatial modules) } \\
\hline \multicolumn{3}{|l|}{ R package } \\
\hline \multicolumn{3}{|l|}{ Theme: Consumer of GIS information $(n=3)$} \\
\hline \multicolumn{3}{|c|}{ Virtual Nature Studio, Eon Vue, 3D Max (not GIS, but consume GIS data) } \\
\hline \multicolumn{3}{|c|}{ Not a GIS user, but information user from GIS professionals } \\
\hline \multicolumn{3}{|c|}{$\begin{array}{l}\text { I am not GIS proficient, I use GAP information that is compiled by others who } \\
\text { are proficient with GIS }\end{array}$} \\
\hline \multicolumn{3}{|c|}{ Theme: $\operatorname{ArcMap}(n=2)$} \\
\hline \multicolumn{3}{|l|}{ ArcMap10 } \\
\hline \multicolumn{3}{|l|}{ ArcMap } \\
\hline \multicolumn{3}{|l|}{ No theme: } \\
\hline We have technical people who do the manipulation & & \\
\hline
\end{tabular}




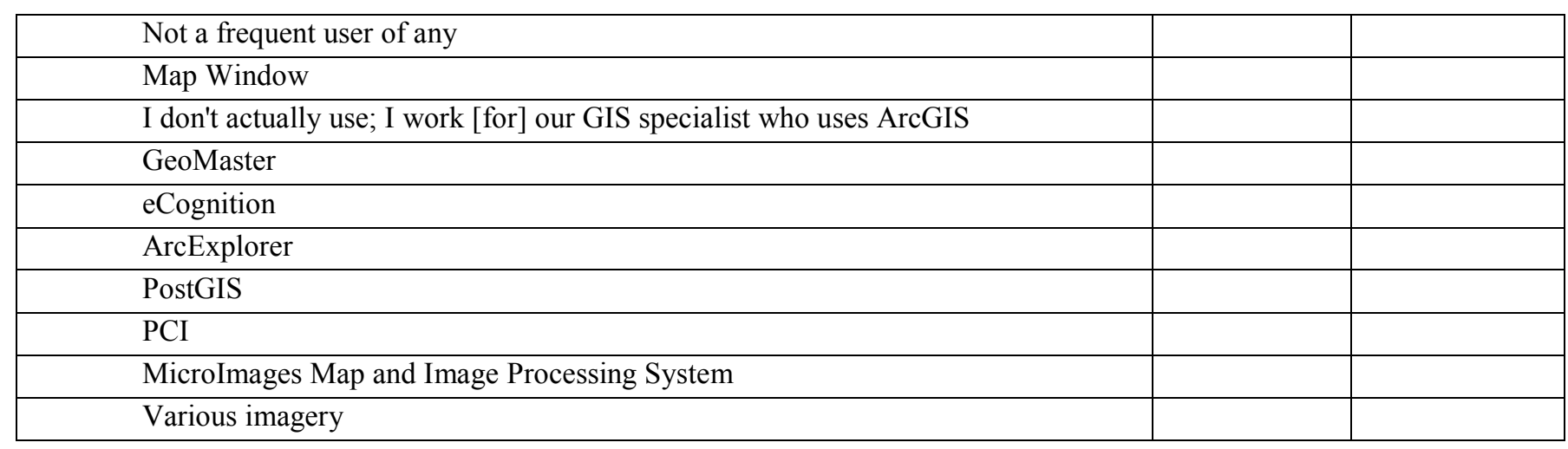

Q122 Which GIS software packages do you have access to but only occasionally use? (Select all that apply.) ( $n=186)$

\begin{tabular}{|c|c|c|}
\hline Response & $\begin{array}{c}\text { Number of } \\
\text { times selected }\end{array}$ & Percent \\
\hline a. ArcView & 66 & 35 \\
\hline b. ArcGIS & 51 & 27 \\
\hline c. Imagine & 68 & 37 \\
\hline d. GRASS & 21 & 11 \\
\hline e. ENVI & 41 & 22 \\
\hline f. Maplnfo & 16 & 9 \\
\hline g. Manifold & 2 & 1 \\
\hline h. Idrisi & 21 & 11 \\
\hline i. Other: [open-ended response] & 18 & 10 \\
\hline \multicolumn{3}{|l|}{ Theme: Quantum GIS $(n=3)$} \\
\hline \multicolumn{3}{|l|}{ Quantum GIS } \\
\hline \multicolumn{3}{|l|}{ QGIS (2) } \\
\hline \multicolumn{3}{|l|}{ Theme: None $(n=3)$} \\
\hline \multicolumn{3}{|l|}{ Not even an occasional user now } \\
\hline \multicolumn{3}{|l|}{ None (2) } \\
\hline \multicolumn{3}{|l|}{ Theme: uDIG $(n=2)$} \\
\hline \multicolumn{3}{|l|}{ uDIG (2) } \\
\hline \multicolumn{3}{|l|}{ No theme: } \\
\hline \multicolumn{3}{|l|}{ Spring } \\
\hline \multicolumn{3}{|l|}{ Same as above } \\
\hline \multicolumn{3}{|l|}{ Random Forest } \\
\hline \multicolumn{3}{|l|}{ Program R } \\
\hline \multicolumn{3}{|l|}{ Not sure } \\
\hline \multicolumn{3}{|l|}{ Global Mapper } \\
\hline \multicolumn{3}{|l|}{ Geo Media } \\
\hline \multicolumn{3}{|l|}{ eCognition } \\
\hline \multicolumn{3}{|l|}{ Biotas } \\
\hline Mapwindow & & \\
\hline
\end{tabular}


Q123

Do you prefer to: $(n=276)$

\begin{tabular}{|l|c|}
\hline Response & Percent \\
\hline a. Access Web-based GIS tools/datasets. & 8 \\
\hline b. Download data for use in your GIS system. & $\mathbf{5 8}$ \\
\hline c. I have equal preference for each of the above options. & 34 \\
\hline
\end{tabular}

Q124 When you are obtaining GIS data in general, which delivery option do you prefer? $(n=274)$

\begin{tabular}{|l|c|}
\hline Response & Percent \\
\hline a. File Transfer Protocol (FTP) & 26 \\
\hline b. Direct Download & $\mathbf{6 6}$ \\
\hline c. Receive on CD-ROM, DVD, or external hard drive for large datasets & 6 \\
\hline d. Other: [open-ended response] & 3 \\
\hline Theme: No opinion ( $n=2)$ & \\
\hline No opinion & \\
\hline It doesn't matter to me & \\
\hline No theme: & \\
\hline Map services & \\
\hline I think our GIS guy likes FTP, but I'm not sure & \\
\hline Feature data service, direct connect & \\
\hline Depends on size of dataset & \\
\hline All three & \\
\hline ANYTHING BUT FTP - NO FTP!!!!! OUR NETWORK FOLKS DON"T ALLOW IT!!! & \\
\hline
\end{tabular}

Q125 In general when you download GIS raster data (GAP or other), which format do you most frequently use? ( $n$ = 249)

\begin{tabular}{|l|c|}
\hline Response & Percent \\
\hline a. ESRI GRID (Interchange format) & $\mathbf{5 6}$ \\
\hline b. Geotiff & 23 \\
\hline c. Spatial Data Transfer Standard (SDTS) & 3 \\
\hline d. ERDAS .img & 9 \\
\hline e. Other: [open-ended response] & 10 \\
\hline Theme: Don't know ( $n=7)$ & \\
\hline Unknown (2) & \\
\hline I don't know. (2) & \\
\hline Don't know (2) & \\
\hline I don't know..the default? & \\
\hline Theme: Someone else does this ( $n=3)$ & \\
\hline Someone else in my office does this for us & \\
\hline Not sure which he does & \\
\hline I don't know. Done by GIS specialist & \\
\hline Theme: Shapefile $(n=2)$ & \\
\hline Shapefile and kml & \\
\hline Shapefile & \\
\hline Theme: Equal preference ( $n=2)$ & \\
\hline ESRI GRID and ERDAS .img equally & \\
\hline Equally prefer Grid and GeoTiff, dependent upon what we are doing & \\
\hline
\end{tabular}




\begin{tabular}{|l|l|}
\hline Theme: Don't download $(n=2)$ & \\
\hline I don't usually download it. & \\
\hline I don't generally download GIS data & \\
\hline No theme: & \\
\hline Usually access data directly from ArcSDE. & \\
\hline Use GIS inhouse server & \\
\hline NA & \\
\hline GDAL/OGR imports to GRASS; generate GeoTIFFs; use in QGIS & \\
\hline File geodatabase & \\
\hline Any or all & \\
\hline
\end{tabular}

Q126 When you download GAP raster data, which format do you most frequently use? $(n=247)$

\begin{tabular}{|c|c|}
\hline 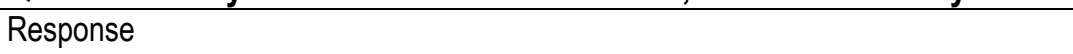 & Percent \\
\hline a. ESRI GRID (Interchange format) & 60 \\
\hline b. Geotiff & 15 \\
\hline c. ERDAS .img & 9 \\
\hline d. Use all with roughly the same frequency & 4 \\
\hline e. Use none of the above. I use other: [open-ended response] & 13 \\
\hline \multicolumn{2}{|l|}{ Theme: Don't know $(n=7)$} \\
\hline \multicolumn{2}{|l|}{ Unknown (2) } \\
\hline \multicolumn{2}{|l|}{ I don't know. (2) } \\
\hline \multicolumn{2}{|l|}{ Don't know (2) } \\
\hline \multicolumn{2}{|l|}{ I don't know..the default? } \\
\hline \multicolumn{2}{|l|}{ Theme: Don't download $(n=5)$} \\
\hline \multicolumn{2}{|l|}{ I haven't downloaded anytime recently } \\
\hline \multicolumn{2}{|l|}{ I don't need to download gap data } \\
\hline \multicolumn{2}{|l|}{ I don't download it. } \\
\hline \multicolumn{2}{|l|}{ I don't download GAP raster data } \\
\hline \multicolumn{2}{|l|}{ I don't anymore } \\
\hline \multicolumn{2}{|l|}{ Theme: Already have data $(n=3)$} \\
\hline \multicolumn{2}{|l|}{ Data I have access to now. } \\
\hline \multicolumn{2}{|l|}{ Already had data. } \\
\hline \multicolumn{2}{|l|}{ The GAP data on my computer which I helped create } \\
\hline \multicolumn{2}{|l|}{ Theme: Vector data $(n=2)$} \\
\hline \multicolumn{2}{|l|}{ Vector data from website } \\
\hline \multicolumn{2}{|l|}{ Usually use GAP data that is already in vector format } \\
\hline \multicolumn{2}{|l|}{ No theme: } \\
\hline \multicolumn{2}{|l|}{ Use GIS inhouse server } \\
\hline \multicolumn{2}{|l|}{ Shapefile } \\
\hline \multicolumn{2}{|l|}{ NA } \\
\hline \multicolumn{2}{|l|}{ MN DNR core GIS library geodatabase } \\
\hline \multicolumn{2}{|l|}{ I have only used GAP feature data, not rasters. } \\
\hline \multicolumn{2}{|l|}{ GDAL/OGR imports to GRASS; generate GeoTIFFs; use in QGIS } \\
\hline \multicolumn{2}{|l|}{ Convert to dissolved feature class polygon } \\
\hline Someone else does the downloading for us & \\
\hline
\end{tabular}


Q127 How satisfied are you with the speed with which you can download GAP data? $(n=249$, average $=4)$

\begin{tabular}{|c|c|c|c|c|}
\hline $\begin{array}{l}\text { a. Completely } \\
\text { dissatisfied } \\
\text { (1) }\end{array}$ & $\begin{array}{l}\text { b. Somewhat dissatisfied } \\
\text { (2) }\end{array}$ & $\begin{array}{l}\text { c. Neither satisfied nor } \\
\text { dissatisfied } \\
\text { (3) }\end{array}$ & $\begin{array}{l}\text { d. Somewhat satisfied } \\
\text { (4) }\end{array}$ & $\begin{array}{l}\text { e. Completely satisfied } \\
\text { (5) }\end{array}$ \\
\hline $1 \%$ & $5 \%$ & $43 \%$ & $32 \%$ & $20 \%$ \\
\hline
\end{tabular}

\section{Learning to Use GAP Data}

Q128 How difficult was it for you to use GAP data the first time you used it? $(n=270$, average $=3$ )

\begin{tabular}{|c|c|c|c|c|}
\hline $\begin{array}{l}\text { a. Very difficult } \\
\text { (1) }\end{array}$ & $\begin{array}{l}\text { b. Somewhat difficult } \\
\text { (2) }\end{array}$ & $\begin{array}{l}\text { c. Neither difficult nor } \\
\text { easy } \\
\text { (3) }\end{array}$ & $\begin{array}{c}\text { d. Somewhat easy } \\
\text { (4) }\end{array}$ & $\begin{array}{l}\text { e. Very easy } \\
\text { (5) }\end{array}$ \\
\hline $5 \%$ & $25 \%$ & $36 \%$ & $20 \%$ & $14 \%$ \\
\hline
\end{tabular}

Q129 If you had a question about using GAP data, what would your most likely course of action be? $(n=274)$

\begin{tabular}{|l|c|}
\hline Response & Percent \\
\hline a. Go online to the GAP web site to find information & $\mathbf{4 1}$ \\
\hline b. Go online to the GAP web site to use one of the online data viewers & 4 \\
\hline c. Go online but not to the GAP web site. I'd search for other GAP users & 2 \\
\hline d. Contact someone I know who has previously used GAP & 12 \\
\hline e. Contact someone I know who worked on a GAP project & 9 \\
\hline f. Contact a current GAP staff member & 7 \\
\hline g. Contact someone I know who has GIS knowledge & 4 \\
\hline h. Other: [open-ended response] & \\
\hline Theme: Metadata (n = 4) & \\
\hline Read the metadata & \\
\hline $\begin{array}{l}\text { Read the included metadata, which I would have downloaded at the same time if it wasn't } \\
\text { packaged together. See, at least one person does! }\end{array}$ & \\
\hline Metadata, ask around and call GAP & \\
\hline Consult the metadata first. Then go online. Then contact someone I know with GAP experience. & \\
\hline No theme: & \\
\hline Talk to myself - I was the PI for a state project. & \\
\hline I would use a combination of the first, fourth, and fifth options. & \\
\hline Google the question & \\
\hline Could be any of the above & \\
\hline Ask district GIS staff & \\
\hline $\begin{array}{l}\text { We have our own in-house copy of the data. National website/FTP server kept changing making } \\
\text { it difficult for others to locate the data. }\end{array}$ & \\
\hline
\end{tabular}

Q130 How valuable would training on the use of GAP data be to you? $(n=282$, average $=2)$

\begin{tabular}{|c|c|c|c|}
\hline $\begin{array}{c}\text { a. Not at all valuable } \\
\text { (1) }\end{array}$ & b. Somewhat valuable & c. Moderately valuable & d. Very valuable \\
$(\mathbf{2})$ & $\mathbf{5 2 \%}$ & $13 \%$ & $10 \%$ \\
\hline $25 \%$ & $\mathbf{5 2 \%}$ & & $10 \%$ \\
\hline
\end{tabular}


If respondents indicated that training on the use of GAP data would be valuable (any response to Q130 other than "Not at all valuable"), they were directed to Q131. If respondents indicated the training would not be at all valuable, then they were directed next to Q137.

Q131 How much would you be willing to pay, if necessary, for course registration for a one day training course on using GAP data? ( $n=203)$

\begin{tabular}{|l|c|}
\hline Response & Percent \\
\hline a. Only a negligible amount, definitely less than $\$ \mathbf{1 0 0}$ & $\mathbf{4 3}$ \\
\hline b. $\$ 100-200$ & 37 \\
\hline c. $\$ 201-300$ & 6 \\
\hline d. $\$ 301-400$ & 3 \\
\hline e. $\$ 401-500$ & 2 \\
\hline f. Over $\$ 500$ & \\
\hline g. I would not be willing to pay any amount. & 8 \\
\hline
\end{tabular}

Q132 How valuable would training on the use of GIS data as a tool for conservation decisionmaking (that used GAP data as an example) be to you? ( $n=204$, average $=2)$

\begin{tabular}{|c|c|c|c|}
\hline $\begin{array}{c}\text { a. Not at all valuable } \\
\text { (1) }\end{array}$ & $\begin{array}{c}\text { b. Somewhat valuable } \\
(\mathbf{2})\end{array}$ & $\begin{array}{c}\text { c. Moderately valuable } \\
(3)\end{array}$ & $\begin{array}{c}\text { d. Very valuable } \\
(4)\end{array}$ \\
\hline $16 \%$ & $\mathbf{5 0 \%}$ & $18 \%$ & $17 \%$ \\
\hline
\end{tabular}

Q133 How much would you be willing to pay, if necessary, for course registration for a one day training course on GIS data as a tool for conservation decisionmaking that used GAP data as an example? $(n=202)$

\begin{tabular}{|l|c|}
\hline Response & Percent \\
\hline a. Only a negligible amount, definitely less than $\$ \mathbf{1 0 0}$ & $\mathbf{3 9}$ \\
\hline b. $\$ 100-200$ & 34 \\
\hline c. $\$ 201-300$ & 8 \\
\hline d. $\$ 301-400$ & 4 \\
\hline e. $\$ 401-500$ & 2 \\
\hline f. Over \$500 & 1 \\
\hline g. I would not be willing to pay any amount. & 14 \\
\hline
\end{tabular}

Q134 If you were to attend training on use of GAP data, what would be your preference for length of training? $(n=$ 207)

\begin{tabular}{|c|c|c|c|}
\hline a. $1 / 2$ day & b. 1 day & c. 2 days & d. I would not attend training \\
\hline $11 \%$ & $\mathbf{6 9 \%}$ & $15 \%$ & $5 \%$ \\
\hline
\end{tabular}

Q135 In your opinion, which of the following would be the most effective training method (for best learning) on the use of GAP data? $(n=207)$

\begin{tabular}{|l|c|}
\hline Response & Percent \\
\hline a. Training session—Instructor led classroom & $\mathbf{5 4}$ \\
\hline b. Training session—Instructor led web-based & 22 \\
\hline c. Training session held in conjunction with a conference & 9 \\
\hline d. Online tutorial & 12 \\
\hline e. Online Help desk—questions would be responded to by a member of the GAP staff & 3 \\
\hline
\end{tabular}


Q136 Which of the following would be the most practical training method (training that could be completed within the realistic constraints of time and budget) on the use of GAP data? $(n=204)$

\begin{tabular}{|l|c|}
\hline Response & Percent \\
\hline a. Training session—Instructor led classroom & 13 \\
\hline b. Training session—Instructor led web-based & $\mathbf{4 0}$ \\
\hline c. Training session held in conjunction with a conference & 13 \\
\hline d. Online tutorial & 33 \\
\hline e. Online Help desk—questions would be responded to by a member of the GAP staff & 2 \\
\hline
\end{tabular}

Q137 How satisfied are you with the support you have received from GAP staff in your use of GAP data? $(n=143$, average $\mathbf{~} 4$ )

\begin{tabular}{|c|c|c|c|c|c|}
\hline $\begin{array}{c}\text { I have never } \\
\text { received any } \\
\text { support from } \\
\text { GAP staff } \\
\text { (no value) }\end{array}$ & $\begin{array}{c}\text { a. Completely } \\
\text { dissatisfied }\end{array}$ & $\begin{array}{c}\text { b. Somewhat } \\
\text { dissatisfied }\end{array}$ & $\begin{array}{c}\text { C. Neither } \\
\text { dissatisfied nor } \\
\text { satisfied }\end{array}$ & $\begin{array}{c}\text { d. Somewhat } \\
\text { satisfied }\end{array}$ & $\begin{array}{c}\text { e. Completely } \\
\text { satisfied }\end{array}$ \\
\hline $\mathbf{4 8 \%}$ & $(1)$ & $(2)$ & $(3)$ & $(4)$ & $17 \%$ \\
\hline
\end{tabular}

Q138 How satisfied are you with any communication you have had with GAP staff? $(n=159$, average $=4)$

\begin{tabular}{|c|c|c|c|c|c|}
\hline $\begin{array}{c}\text { I have never had } \\
\text { any } \\
\begin{array}{c}\text { communication } \\
\text { with GAP staff } \\
\text { (no value) }\end{array}\end{array}$ & $\begin{array}{c}\text { a. Completely } \\
\text { dissatisfied }\end{array}$ & $\begin{array}{c}\text { b. Somewhat } \\
\text { dissatisfied }\end{array}$ & $\begin{array}{c}\text { c. Neither } \\
\text { dissatisfied nor } \\
\text { satisfied }\end{array}$ & $\begin{array}{c}\text { d. Somewhat } \\
\text { satisfied }\end{array}$ & $\begin{array}{c}\text { e. Completely } \\
\text { satisfied }\end{array}$ \\
\hline $\mathbf{4 2 \%}$ & $(1)$ & $(2)$ & $(3)$ & $(4)$ & $(5)$ \\
\hline
\end{tabular}

Q139 How did you learn to make use of GAP data? $(n=281)$

Respondents were asked different follow-up questions on the basis of their answer to Q139. The follow-up questions are included in the frequency table of responses to Q139.

\begin{tabular}{|c|c|c|}
\hline \multicolumn{2}{|l|}{ Response } & Percent \\
\hline \multicolumn{2}{|l|}{ a. I figured it out myself. } & 45 \\
\hline \multicolumn{3}{|c|}{ Q140 How easy was it to figure out how to use GAP in your work? $(n=121$, average $=4)$} \\
\hline \multicolumn{3}{|c|}{\begin{tabular}{l|l} 
a. Very difficult (1) &
\end{tabular}} \\
\hline b. Somewhat difficult (2) & $13 \%$ & \\
\hline c. Not difficult or easy (3) & $30 \%$ & \\
\hline d. Somewhat easy (4) & $32 \%$ & \\
\hline e. Very easy (5) & $25 \%$ & \\
\hline \multicolumn{2}{|c|}{ b. A colleague helped me learn what I needed to know in order to use the data. } & 32 \\
\hline \multicolumn{2}{|c|}{$\begin{array}{l}\text { Q141 How easy was it to find a colleague who could provide you with the needed assistance? }(n=89, \\
\text { average = 4) }\end{array}$} & \\
\hline a. Very difficult (1) & $2 \%$ & \\
\hline b. Somewhat difficult (2) & $11 \%$ & \\
\hline c. Not difficult or easy (3) & $17 \%$ & \\
\hline d. Somewhat easy (4) & $37 \%$ & \\
\hline e. Very easy (5) & $33 \%$ & \\
\hline \multicolumn{2}{|c|}{ c. A member of GAP staff helped me learn what I needed to know to use the data. } & 14 \\
\hline \multicolumn{2}{|c|}{ Q142 How accessible were GAP staff when you needed assistance? $(n=39$, average $=4)$} & \\
\hline a. Extremely inaccessible (1) & & \\
\hline
\end{tabular}




\begin{tabular}{|l|c|}
\hline b. Somewhat inaccessible (2) & $10 \%$ \\
\hline c. Neither inaccessible or accessible (3) & $15 \%$ \\
\hline d. Somewhat accessible (4) & $\mathbf{3 9 \%}$ \\
\hline e. Extremely accessible (5) & $36 \%$ \\
\hline Q143 How satisfied were you with the assistance you received? ( $n=39$, average = 4) & \\
\hline a. Completely dissatisfied (1) & $3 \%$ \\
\hline b. Somewhat dissatisfied (2) & $8 \%$ \\
\hline c. Neither satisfied or dissatisfied (3) & $13 \%$ \\
\hline d. Somewhat satisfied (4) & $33 \%$ \\
\hline e. Completely satisfied (5) & $\mathbf{4 4 \%}$ \\
\hline d. I used resources on the GAP web site. & \\
\hline
\end{tabular}

\section{Distribution of GAP Data and Products Based on GAP Data}

Q144 How would you characterize GAP's coordination with other agencies to promote awareness and use of GAP datasets? $(n=268)$

\begin{tabular}{|l|c|}
\hline Response & Percent \\
\hline a. Insufficient to the point of rendering unusable the data that GAP provides because of lack of awareness. & 4 \\
\hline $\begin{array}{l}\text { b. Insufficient to the point that the data GAP provides are less widely used than they could be because GAP doesn't } \\
\text { coordinate much with other agencies. }\end{array}$ & 14 \\
\hline $\begin{array}{l}\text { c. Sufficient to the point that the most likely users of GAP data are aware of how to obtain data as the result of GAP } \\
\text { coordination other agencies. }\end{array}$ & 28 \\
\hline $\begin{array}{l}\text { d. Sufficient to the point that both likely and unlikely users are aware of GAP data due to GAP coordination with other } \\
\text { agencies. }\end{array}$ & 8 \\
\hline e. I cannot judge this. & $\mathbf{4 6}$ \\
\hline
\end{tabular}

Q145 Do you personally know someone who was involved in developing a regional GAP project? $(n=264)$

\begin{tabular}{|l|c|}
\hline Response & Percent \\
\hline a. Yes & $\mathbf{6 2}$ \\
\hline b. No & 38 \\
\hline
\end{tabular}

Q146 Do you personally know someone who is currently employed by GAP? $(n=250)$

\begin{tabular}{|l|c|}
\hline Response & Percent \\
\hline a. Yes & 31 \\
\hline b. No & $\mathbf{6 9}$ \\
\hline
\end{tabular}

Q147 Do you personally know someone who was involved in developing a state GAP project? $(n=258)$

\begin{tabular}{|l|c|}
\hline Response & Percent \\
\hline a. Yes & $\mathbf{7 5}$ \\
\hline b. No & 25 \\
\hline
\end{tabular}

Q148 How frequently do you send GAP datasets (in original form, without additions or revisions) to someone else? $(n=276)$

\begin{tabular}{|l|c|}
\hline Response & Percent \\
\hline a. Never & $\mathbf{7 2}$ \\
\hline b. Up to several times a year & 26 \\
\hline
\end{tabular}




\begin{tabular}{|l|c|}
\hline c. Once a month & 2 \\
\hline d. Once a week & \\
\hline e. Daily & $<0.5$ \\
\hline
\end{tabular}

Respondents who indicated that they never send GAP datasets to others were directed to Q150. Respondents who indicated that they send GAP datasets with any degree of frequency were asked a follow-up question (Q149).

Q149 To whom have you distributed GAP data in its original form, without additions or revisions? Select all that apply. $(n=74)$

\begin{tabular}{|l|c|c|}
\hline Response & $\begin{array}{c}\text { Number of } \\
\text { times selected }\end{array}$ & Percent \\
\hline a. A colleague at my workplace & $\mathbf{5 0}$ & $\mathbf{6 8}$ \\
\hline b. A colleague in my local area & 30 & 41 \\
\hline c. A colleague in my state & 45 & 61 \\
\hline d. A colleague in my multi-state region & 29 & 39 \\
\hline e. A colleague in another part of the country & 18 & 24 \\
\hline f. A colleague in another country & 5 & 7 \\
\hline g. None of these descriptions apply & 5 & 7 \\
\hline
\end{tabular}

Q150 How frequently do you direct someone else to the GAP web site to download data? $(n=275)$

\begin{tabular}{|l|c|}
\hline Response & Percent \\
\hline a. Never & $\mathbf{5 3}$ \\
\hline b. Up to several times a year & 46 \\
\hline c. Once a month & 2 \\
\hline d. Once a week & $<0.5$ \\
\hline e. Daily & \\
\hline
\end{tabular}

Respondents who indicated that they never direct someone else to the GAP web site to download data were directed to Q152. Respondents who indicated that they direct someone else to the GAP web site to download data with any degree of frequency were asked a follow-up question (Q151).

Q151 Whom have you directed to the GAP web site to download data? Select all that apply. $(n=129)$

\begin{tabular}{|l|c|c|}
\hline Response & $\begin{array}{c}\text { Number of } \\
\text { times selected }\end{array}$ & Percent \\
\hline a. A colleague at my workplace & $\mathbf{7 8}$ & $\mathbf{6 0}$ \\
\hline b. A colleague in my local area & 38 & 29 \\
\hline c. A colleague in my state & 63 & 49 \\
\hline d. A colleague in my multi-state region & 40 & 31 \\
\hline e. A colleague in another part of the country & 40 & 31 \\
\hline f. A colleague in another country & 6 & 5 \\
\hline g. None of these descriptions apply & 9 & 7 \\
\hline
\end{tabular}

Q152 How frequently do you send others to the GAP web site to use the online data viewers? $(n=275)$

\begin{tabular}{|l|c|}
\hline Response & Percent \\
\hline a. Never & $\mathbf{7 2}$ \\
\hline
\end{tabular}




\begin{tabular}{|l|c|}
\hline b. Up to several times a year & 27 \\
\hline c. Once a month & 1 \\
\hline d. Once a week & $<0.5$ \\
\hline e. Daily & \\
\hline
\end{tabular}

Respondents who indicated that they never send others to the GAP web site to use the online data viewers were directed to Q154. Respondents who indicated that they send others to the GAP web site to use the online data viewers with any degree of frequency were asked a follow-up question (Q153).

Q153 To whom have you recommended using the online data viewers on the GAP web site? Select all that apply. $(n=76)$

\begin{tabular}{|l|c|c|}
\hline Response & $\begin{array}{c}\text { Number of } \\
\text { times selected }\end{array}$ & Percent \\
\hline a. A colleague at my workplace & $\mathbf{3 8}$ & $\mathbf{5 0}$ \\
\hline b. A colleague in my local area & 22 & 29 \\
\hline c. A colleague in my state & 37 & 49 \\
\hline d. A colleague in my multi-state region & 26 & 34 \\
\hline e. A colleague in another part of the country & 22 & 29 \\
\hline f. A colleague in another country & 4 & 5 \\
\hline g. None of these descriptions apply & 11 & 14 \\
\hline
\end{tabular}

Q154 How frequently do you send someone else an information product (map, chart, document) that you created based on GAP data? $(n=275)$

\begin{tabular}{|l|c|}
\hline Response & Percent \\
\hline a. Never & 36 \\
\hline b. Up to several times a year & $\mathbf{5 5}$ \\
\hline c. Once a month & 7 \\
\hline d. Once a week & 3 \\
\hline e. Daily & $<0.5$ \\
\hline
\end{tabular}

Respondents who indicated that they never send someone else an information product that they created based on GAP data were directed to Q158. Respondents who indicated that they do send someone else an information product that they created based on GAP data with any degree of frequency were asked a series of follow-up questions (Q155 through Q157).

Q155 To whom have you distributed the product (dataset, map, chart, or other document) that you made using GAP data? Select all that apply. $(n=173)$

\begin{tabular}{|l|c|c|}
\hline Response & $\begin{array}{c}\text { Number of } \\
\text { times selected }\end{array}$ & Percent \\
\hline a. An individual who makes policy about conservation of biodiversity & 66 & 38 \\
\hline b. An individual who implements policy about conservation of biodiversity & 83 & 48 \\
\hline c. An individual who advocates policy about conservation of biodiversity & 74 & 43 \\
\hline d. An individual who studies conservation of biodiversity & $\mathbf{9 8}$ & $\mathbf{5 7}$ \\
\hline $\begin{array}{l}\text { e. An individual who creates products to be used by those who implement, advocate, or make policy } \\
\text { about biodiversity }\end{array}$ & 77 & 45 \\
\hline f. None of these descriptions apply & 32 & 18 \\
\hline
\end{tabular}


Q156 When you distributed the product (dataset, map, chart, or other document) that you made using GAP data, to how many individuals did you distribute? $(n=172)$

\begin{tabular}{|l|c|}
\hline Response & Percent \\
\hline a. An individual & $\mathbf{2 9}$ \\
\hline b. A small group (3-5) & 27 \\
\hline c. A moderate group (6-10) & 17 \\
\hline d. A large group (11-50) & 13 \\
\hline e. A very large group (such as a listserv) & 1 \\
\hline f. An undefined group (made available to the public) & 13 \\
\hline
\end{tabular}

Q157 When you distributed the product (dataset, map, chart, or other document) that you made using GAP data, how broad was your intended audience? $(n=172)$

\begin{tabular}{|l|c|}
\hline Response & Percent \\
\hline a. Local & 31 \\
\hline b. State & $\mathbf{4 5}$ \\
\hline c. National & 16 \\
\hline d. International & 8 \\
\hline
\end{tabular}

Q158 Who is the primary recipient of the product you make using GAP data? $(n=266)$

\begin{tabular}{|l|c|}
\hline Response & Percent \\
\hline a. Myself, I am the end user & 14 \\
\hline b. Public, I publish & 20 \\
\hline c. Legislators & $<0.5$ \\
\hline d. State planners & 9 \\
\hline e. Land managers & $\mathbf{2 3}$ \\
\hline f. I don't make any type of product using GAP data & 16 \\
\hline g. Other: [open-ended response] & 17 \\
\hline Theme: Multiple types of recipients ( $n=8$ ) & \\
\hline Variety of above as well as students and other academics & \\
\hline Local, State, Federal Agencies, private clients & \\
\hline All of the above & \\
\hline Landowners, working groups, and the public & \\
\hline State professionals and lay people & \\
\hline Public, state employees & \\
\hline Engineering project stakeholders, and for permitting purposes, some agencies & \\
\hline Local planners, land managers, biologists, myself & \\
\hline Theme: Colleagues ( $n=6)$ & \\
\hline Colleagues (2) & \\
\hline Collegues in my organization & \\
\hline Colleagues in other NGOs, landowners, agencies & \\
\hline Work colleagues & \\
\hline Colleague & \\
\hline Theme: Nongovernmental organization ( $n=3$ ) & \\
\hline Scientists at The Nature Conservancy & \\
\hline Non-profit land trusts & \\
\hline
\end{tabular}




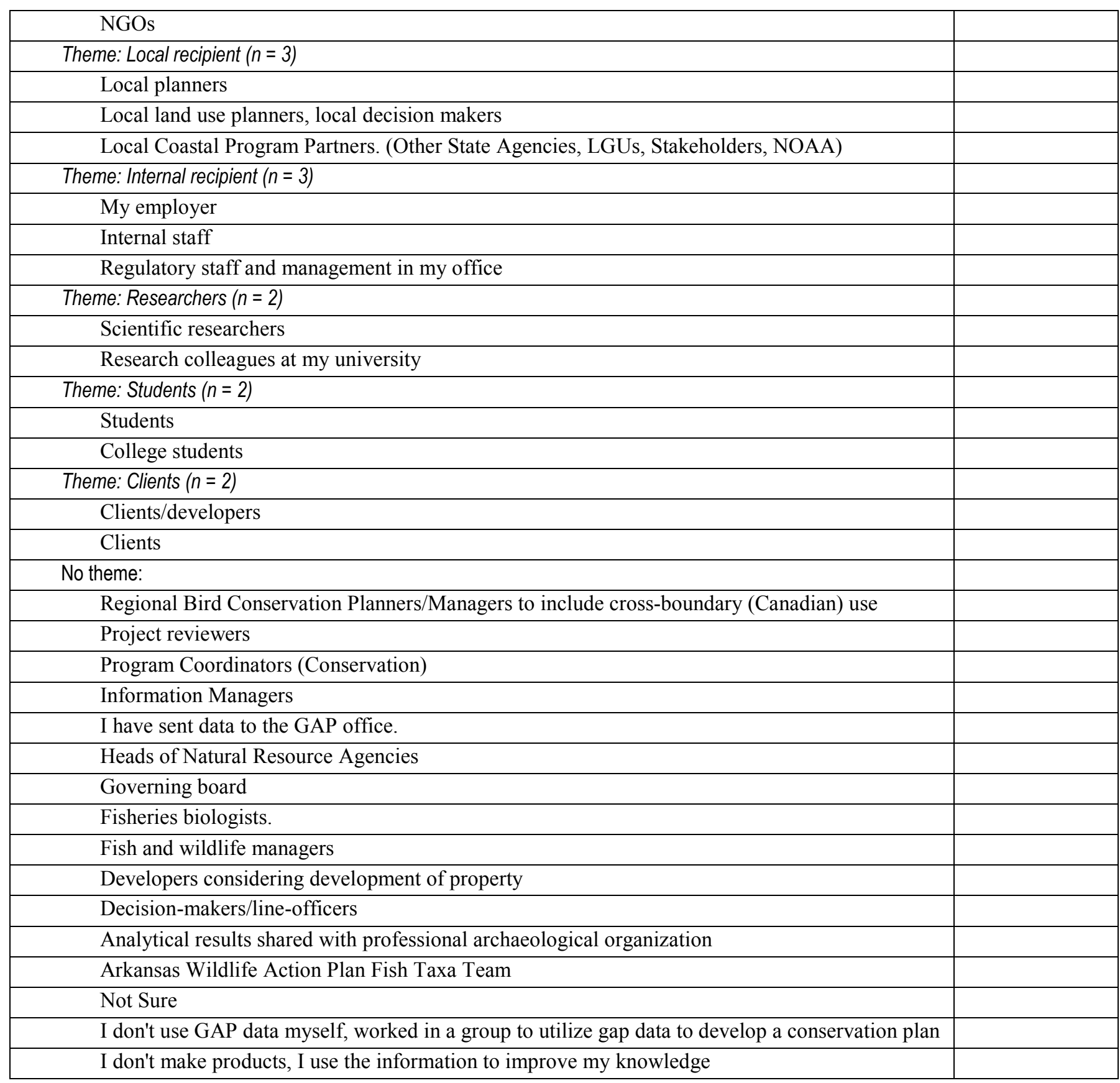

\section{Q159 Which of the following best describes the aspect of decisionmaking present in your current position? $(n=$} 269) Response

a. I make decisions regarding how to define policies affecting conservation of biodiversity.

b. I implement but do not make policies affecting conservation of biodiversity.

c. I provide information products to those who make policies affecting conservation of biodiversity. d. I decide what data to use in creating information products to be used by those who make or implement policies affecting conservation of biodiversity.

e. None of the above 
Q160 Have you ever used a GAP dataset or a product based on GAP data to make a decision that had a direct effect on conservation of biodiversity? $(n=273)$

\begin{tabular}{|l|c|}
\hline Response & Percent \\
\hline a. Yes & 43 \\
\hline b. No & $\mathbf{5 8}$ \\
\hline
\end{tabular}

Respondents who answered "Yes" to Q160 were next asked Q161 through Q163. Respondents who answered "No" to Q160 were next asked Q164 in the next section of the survey. When asked the following questions, respondents were instructed to think about the most recent time when they used a GAP dataset or a product based on GAP data to make a decision that had a direct effect on conservation of biodiversity.

Q161 Without the information that GAP data provided, the decision made would have been very different. $(n=113$, average $=3$ )

\begin{tabular}{|c|c|c|c|c|}
\hline a. Strongly disagree & b. Somewhat disagree & $\begin{array}{c}\text { c. Neither agree nor } \\
\text { disagree } \\
(3)\end{array}$ & $\begin{array}{c}\text { d. Somewhat agree } \\
\text { e. Strongly agree }\end{array}$ & $(5)$ \\
\hline$(1)$ & $(2)$ & $36 \%$ & $\mathbf{3 8 \%}$ & $12 \%$ \\
\hline
\end{tabular}

Q162 How successful would you say GAP data or products were in influencing the decision? $(n=113$, average $=$ 4)

\begin{tabular}{|c|c|c|c|c|}
\hline $\begin{array}{l}\text { a. Very unsuccessful } \\
\text { (1) }\end{array}$ & $\begin{array}{l}\text { b. Somewhat } \\
\text { unsuccessful } \\
\text { (2) }\end{array}$ & $\begin{array}{l}\text { c. Neither successful nor } \\
\text { unsuccessful } \\
\text { (3) }\end{array}$ & $\begin{array}{l}\text { d. Somewhat } \\
\text { successful } \\
\text { (4) }\end{array}$ & $\begin{array}{l}\text { e. Very successful } \\
\text { (5) }\end{array}$ \\
\hline $1 \%$ & $5 \%$ & $13 \%$ & $66 \%$ & $15 \%$ \\
\hline
\end{tabular}

Q163 No decision would have been made without the information provided by GAP data. $(n=113$, average $=2)$

\begin{tabular}{|c|c|c|c|c|}
\hline $\begin{array}{l}\text { a. Strongly disagree } \\
\text { (1) }\end{array}$ & $\begin{array}{l}\text { b. Somewhat disagree } \\
\text { (2) }\end{array}$ & $\begin{array}{l}\text { c. Neither agree nor } \\
\text { disagree } \\
\text { (3) }\end{array}$ & $\begin{array}{l}\text { d. Somewhat agree } \\
\text { (4) }\end{array}$ & $\begin{array}{l}\text { e. Strongly agree } \\
\text { (5) }\end{array}$ \\
\hline $36 \%$ & $26 \%$ & $27 \%$ & $6 \%$ & $5 \%$ \\
\hline
\end{tabular}

\section{Opinions of Possible Future Actions}

This section of the survey includes questions regarding actions that GAP could take in the future to maximize the usefulness of its data.

Q164 Which database is most important to keep current? $(n=264)$

\begin{tabular}{|l|c|}
\hline Response & Percent \\
\hline a. Land cover & $\mathbf{6 2}$ \\
\hline b. Predicted species distributions & 22 \\
\hline c. Stewardship/protected areas & 16 \\
\hline
\end{tabular}

Q165 Which is more important, to update existing data or to create new data? $(n=262)$

\begin{tabular}{|l|c|}
\hline Response & Percent \\
\hline a. Update existing & $\mathbf{8 2}$ \\
\hline b. Create new & 18 \\
\hline
\end{tabular}


Q166 What is the most important characteristic for future GAP data? $(n=262)$

\begin{tabular}{|l|c|}
\hline Response & Percent \\
\hline a. That it be comparable to the current (regional) and past (state) GAP data & 28 \\
\hline b. That it be at a higher resolution & $\mathbf{3 3}$ \\
\hline c. That it be at a lower resolution & 17 \\
\hline d. That it be developed more closely with the individuals who will be primary users of the data & 22 \\
\hline e. That it be seamless and nation-wide & \\
\hline
\end{tabular}

Q167 I intend to use new releases of GAP data in the future. $(n=265$, average $=4)$

\begin{tabular}{|c|c|c|c|c|}
\hline a. Strongly disagree & b. Somewhat disagree & $\begin{array}{c}\text { c. Neither agree nor } \\
\text { disagree } \\
(3)\end{array}$ & $\begin{array}{c}\text { d. Somewhat agree } \\
\text { e. Strongly agree }\end{array}$ & (5) \\
\hline (1) & $(2)$ & $20 \%$ & $31 \%$ & $\mathbf{4 1 \%}$ \\
\hline
\end{tabular}

Q168 I would use national level GAP data. ( $n=264$, average $=3$ )

\begin{tabular}{|c|c|c|c|c|}
\hline a. Strongly disagree & b. Somewhat disagree & $\begin{array}{c}\text { c. Neither agree nor } \\
\text { disagree } \\
(3)\end{array}$ & $\begin{array}{c}\text { d. Somewhat agree } \\
\text { e. Strongly agree }\end{array}$ & (4) \\
\hline$(1)$ & $(2)$ & $24 \%$ & $\mathbf{3 3 \%}$ & $21 \%$ \\
\hline $8 \%$ & $15 \%$ & $5)$ & 0 \\
\hline
\end{tabular}

Q169 What process change would have the greatest effect on improving use of GAP data? $(n=256)$

\begin{tabular}{|l|c|}
\hline Response & Percent \\
\hline a. Correcting errors/omissions in existing datasets & $\mathbf{3 5}$ \\
\hline b. Creating datasets more quickly from newer data & 33 \\
\hline c. Incorporation of aquatic GAP datasets & 13 \\
\hline $\begin{array}{l}\text { d. Provision of a GAP Helpdesk, where users could submit technical questions and issues for response by a GAP } \\
\text { staff member }\end{array}$ & 1 \\
\hline e. Training offered on use of GAP data & 7 \\
\hline f. Aggressive marketing of GAP data to potential users & 6 \\
\hline g. Other: [open-ended response] & 6 \\
\hline Theme: Don't know ( $n=6)$ & \\
\hline Unknown (2) & \\
\hline No opinion & \\
\hline No idea & \\
\hline I don't know how others are using it so I don't know & \\
\hline Don't know & \\
\hline Theme: Update ( $n=2)$ & \\
\hline Updating/creating new higher spatial resolution state/regional seamless data sets. Current & \\
\hline regional dataset based on LANDFIRE data have many omission commision errors & \\
\hline Updating land cover & \\
\hline No theme: & \\
\hline Understanding the problem users have with the current data limitations to make a better product & \\
\hline Standardize processes & \\
\hline Refining vegetation breaks & \\
\hline Making data available in non-proprietary formats & \\
\hline Making all states' GAP data equally available & \\
\hline
\end{tabular}




\begin{tabular}{|l|l|}
\hline $\begin{array}{l}\text { Make the aquatic gap products available and finish for the nation. There are aquatic gap projects } \\
\text { that have been completed up to two years ago but those datasets have not been made available. }\end{array}$ & \\
\hline Accuracy assessment & \\
\hline Better base data layers, better process for analyses & \\
\hline
\end{tabular}

Q170 How useful would it be to have access to an individual to answer questions about using GAP data? $(n=257$, average $\mathbf{= 2 \text { ) }}$

\begin{tabular}{|c|c|c|c|}
\hline $\begin{array}{c}\text { a. Not at all useful } \\
(1)\end{array}$ & $\begin{array}{c}\text { b. Somewhat useful } \\
\text { (2) }\end{array}$ & $\begin{array}{c}\text { c. Moderately useful } \\
(3)\end{array}$ & $\begin{array}{c}\text { d. Very useful } \\
(4)\end{array}$ \\
\hline $11 \%$ & $\mathbf{5 8 \%}$ & $19 \%$ & $12 \%$ \\
\hline
\end{tabular}

Q171 How useful would it be to have access to an individual who could help you modify GAP data for specific use? $(n=258$, average $=2$ )

\begin{tabular}{|c|c|c|c|}
\hline $\begin{array}{c}\text { a. Not at all useful } \\
\text { (1) }\end{array}$ & $\begin{array}{c}\text { b. Somewhat useful } \\
\mathbf{( 2 )}\end{array}$ & $\begin{array}{c}\text { c. Moderately useful } \\
(3)\end{array}$ & $\begin{array}{c}\text { d. Very useful } \\
(4)\end{array}$ \\
\hline $16 \%$ & $\mathbf{5 2 \%}$ & $16 \%$ & $16 \%$ \\
\hline
\end{tabular}

\section{Outreach Methods}

GAP is interested in learning about effective means by which to communicate with current and potential users of GAP data. This section of the survey included questions asking respondents' opinions about possible outreach methods.

\section{Q172 What factors would affect your attendance at a GAP conference? (select all that apply) $(n=264)$}

\begin{tabular}{|l|c|c|}
\hline Response & $\begin{array}{c}\text { Number of } \\
\text { times selected }\end{array}$ & Percent \\
\hline a. Cost & $\mathbf{2 0 6}$ & $\mathbf{7 8}$ \\
\hline b. Location & 182 & 69 \\
\hline c. Supervisory permission & 88 & 33 \\
\hline d. Topics covered at the conference & 155 & 59 \\
\hline e. Educational/Training Credit & 10 & 4 \\
\hline f. Other: [open-ended response] & 15 & 6 \\
\hline Theme: Relevance ( $n=3)$ & & \\
\hline Relevancy to my work & & \\
\hline Not relevant to current position. & & \\
\hline Ability of new GAP data to meet the needs of my job & & \\
\hline Theme: Timing ( $n=2)$ & & \\
\hline Timing of conference & & \\
\hline Time of year - would prefer summer & & \\
\hline Theme: Multiple factors ( $n=2)$ & & \\
\hline All or the above with exception of last & & \\
\hline All of the above & & \\
\hline No theme: & & \\
\hline Would not attend & & \\
\hline Relationship to Gap Data Use & & \\
\hline Only if I were a presenter & & \\
\hline
\end{tabular}




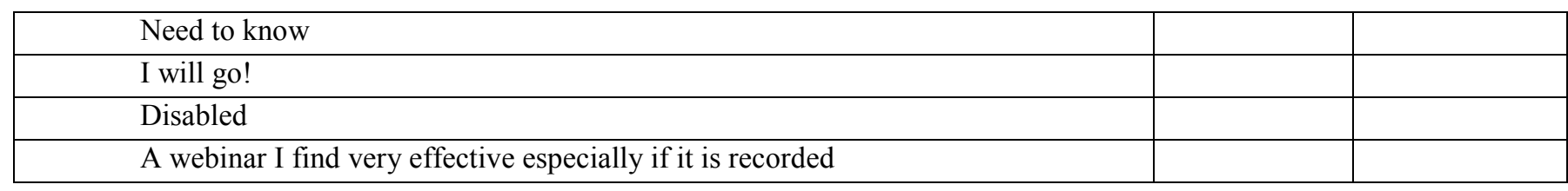

Q173 How likely is it that you would attend an annual GAP conference? $(n=270$, average $=3)$

\begin{tabular}{|c|c|c|c|c|}
\hline $\begin{array}{l}\text { a. Very unlikely } \\
\text { (1) }\end{array}$ & $\begin{array}{l}\text { b. Somewhat unlikely } \\
\text { (2) }\end{array}$ & $\begin{array}{l}\text { c. Neither likely nor } \\
\text { unlikely } \\
\text { (3) }\end{array}$ & $\begin{array}{l}\text { d. Somewhat likely } \\
\text { (4) }\end{array}$ & $\begin{array}{l}\text { e. Very likely } \\
\text { (5) }\end{array}$ \\
\hline $26 \%$ & $24 \%$ & $21 \%$ & $25 \%$ & $4 \%$ \\
\hline
\end{tabular}

If respondents indicated they would be "Very unlikely" to attend an annual GAP conference, they skipped Q174 through Q176 and were asked Q177. Respondents who selected any other option for Q173 were asked Q174 through Q176.

Q174 What topic would you most like to see covered at a GAP conference? Select one. $(n=195)$

\begin{tabular}{|c|c|}
\hline Response & Percent \\
\hline a. Demonstrations by GAP staff of the uses of various GAP datasets & 20 \\
\hline b. Submissions and presentations by others demonstrating how they have used GAP data & 35 \\
\hline c. Ongoing discussions about the advantages and limitations of using GAP data & 16 \\
\hline d. In-depth workshops on how to use GAP data & 11 \\
\hline e. Presentations on current and in-development GIS software & 2 \\
\hline f. Presentations/discussions on conservation of biodiversity & 10 \\
\hline g. Other: [open-ended response] & 6 \\
\hline \multicolumn{2}{|l|}{ Theme: Aquatic data $(n=2)$} \\
\hline \multicolumn{2}{|l|}{ Aquatic GAP projects } \\
\hline \multicolumn{2}{|l|}{ Using Arkansas aquatic gap data - specific. } \\
\hline \multicolumn{2}{|l|}{ No theme: } \\
\hline \multicolumn{2}{|l|}{ Working sessions with GAP staff to create better products } \\
\hline \multicolumn{2}{|l|}{ Results from research } \\
\hline \multicolumn{2}{|l|}{ Present/discussions on updating datasets, maintaining time-relevant info } \\
\hline \multicolumn{2}{|l|}{ Informaton on how products are improving } \\
\hline \multicolumn{2}{|l|}{ Funding for GAP state programs } \\
\hline \multicolumn{2}{|l|}{ Error modeling and confidence mapping } \\
\hline \multicolumn{2}{|l|}{$\begin{array}{l}\text { Discussion or training in conservation planning/landscape ecology methodology that I am not } \\
\text { already familiar with (e.g. new/cutting edge methods, not the same stuff I've been doing for } \\
\text { years), as it pertains to GAP data of course. Incorporation of climate change concerns in } \\
\text { particular. }\end{array}$} \\
\hline Data and metadata management & \\
\hline Bullets 2,3 , and 5 & \\
\hline
\end{tabular}

Q175 How likely is it that you would submit a presentation to a GAP conference? $(n=197$, average $=2$ )

\begin{tabular}{|c|c|c|c|c|}
\hline $\begin{array}{l}\text { a. Very unlikely } \\
\text { (1) }\end{array}$ & $\begin{array}{l}\text { b. Somewhat unlikely } \\
\text { (2) }\end{array}$ & $\begin{array}{l}\text { c. Neither likely nor } \\
\text { unlikely } \\
\text { (3) }\end{array}$ & $\begin{array}{l}\text { d. Somewhat likely } \\
\text { (4) }\end{array}$ & $\begin{array}{l}\text { e. Very likely } \\
\text { (5) }\end{array}$ \\
\hline $31 \%$ & $23 \%$ & $21 \%$ & $19 \%$ & $6 \%$ \\
\hline
\end{tabular}


Q176 How useful would it be to have access to the proceedings from a GAP conference? $(n=194$, average $=3)$

\begin{tabular}{|c|c|c|c|}
\hline $\begin{array}{c}\text { a. Not at all useful } \\
(1)\end{array}$ & $\begin{array}{c}\text { b. Somewhat useful } \\
\text { (2) }\end{array}$ & $\begin{array}{c}\text { c. Moderately useful } \\
(3)\end{array}$ & $\begin{array}{c}\text { d. Very useful } \\
(4)\end{array}$ \\
\hline $4 \%$ & $\mathbf{4 1 \%}$ & $31 \%$ & $25 \%$ \\
\hline
\end{tabular}

\section{Q177 What outreach activity would be most useful in reaching potential users of GAP data? [open-ended response] $(n=106)$}

If a respondent made multiple comments, the comments were split into independent components before the responses were summarized.

\begin{tabular}{|c|c|}
\hline Response & \\
\hline Them & ne: Webinars $(n=14)$ \\
\hline & Webinars (5) \\
\hline & Webinar announced through LCCs, Western Governor's Association, other regional organizations. \\
\hline & Webinar and Web-based training \\
\hline & Recorded webinars showing applied uses of gap data, perhaps content suggested by users \\
\hline & Probably trainings, webinars. \\
\hline & Perhaps web-based seminars \\
\hline & Online tutorials or webinars \\
\hline & Free Online Seminars \\
\hline & Online webinars \\
\hline & Email and short $1 / 2$ hour webinars. \\
\hline Them & ne: GAP presence at other conferences $(n=12)$ \\
\hline & Presence at state wide GIS conferences \\
\hline & $\begin{array}{l}\text { Perhaps rather than reinvigorating the GAP meetings, aim for a consistent presence at other major conferences; like } \\
\text { ESA, and with close partner meetings, like NatureServe's annual meeting. A Gap booth with contributed } \\
\text { papers/workshops might be more effective given limited travel budgets. }\end{array}$ \\
\hline & Outreach in coordination with existing conferences and meetings. \\
\hline & $\begin{array}{l}\text { I think that you probably reach the widest audience by having presentations/posters at conferences. That is where I } \\
\text { learned about the national seamless distribution models. }\end{array}$ \\
\hline & Having a GAP session or training at ecological conferences. \\
\hline & Hard to say, presence at the major conferences (e.g., ESRI UC, SCB, Ecology) \\
\hline & GAP presentations at state, regional, national level fisheries/wildlife meetings \\
\hline & Conference level \\
\hline & Attendance at state conferences such as the conferences for state chapters of The Wildlife Society. \\
\hline & Attendance at national and international ecological conferences \\
\hline & Presentations at other professional conferences. \\
\hline & Session at a state GIS Conference. \\
\hline Them & ne: GAP hosts meetings in local areas $(n=12)$ \\
\hline & Speakers coming to our state \\
\hline & Regional workshops. \\
\hline & Regional meetings \\
\hline & Regional conference \\
\hline & Meeting with State planners. \\
\hline & Meet with indiv state agencies \\
\hline & Local meetings with current and potential GAP data users. \\
\hline & $\begin{array}{l}\text { Have USGS GAP instructors come to our institution to teach GAP and collaborate on GAP-related projects with my } \\
\text { state agency. }\end{array}$ \\
\hline
\end{tabular}




\begin{tabular}{|c|}
\hline $\begin{array}{l}\text { Have local half-day presentations in each state for GIS users. Get them out of the office with their full attention on } \\
\text { GAP data, show them uses and limitations, and take their feedback on what their needs are. }\end{array}$ \\
\hline Have a multi-state (regional) GAP Conference. \\
\hline Area training sessions on its use \\
\hline $\begin{array}{l}\text { A one day course on the use of GAP data that is cheap and in my state/city. With topics useful enough so that my } \\
\text { supervisor can justify sending people. }\end{array}$ \\
\hline Theme: Email $(n=8)$ \\
\hline E-mail (3) \\
\hline Email/website information \\
\hline Email users who've registered themselves as users of GAP data. \\
\hline Email newsletters \\
\hline Sending an email with a link to the web site, and links to different web pages on the site \\
\hline Email marketing through conservation societies \\
\hline Theme: Publication $(n=6)$ \\
\hline Scientific publication \\
\hline Publish results in peer reviewed journals. \\
\hline Publications that show how GAP data are being used \\
\hline Publications that illustrate how GAP data has been used for conservation. \\
\hline Editing an indexed journal which would publish results from research related to gap analysis. \\
\hline $\begin{array}{l}\text { Reference in National Press, Use as primary data source in Professional Journals (Science, Nature, Annals of A } \\
\text { Geographers, Biodiversity, etc). }\end{array}$ \\
\hline Theme: Web site $(n=5)$ \\
\hline Web site \\
\hline Up to date web-site \\
\hline Website with use cases with frequent posts \\
\hline $\begin{array}{l}\text { Posting Gap products and links to published papers and unpublished reports using Gap on the Gap website (and } \\
\text { keeping the site current) }\end{array}$ \\
\hline $\begin{array}{l}\text { Better, more functional website; fewer sites to go to for federal GIS data; better SDMs, with better documentation } \\
\text { about how they were made }\end{array}$ \\
\hline Theme: Collaboration/Coordination with individuals and other groups $(n=5)$ \\
\hline Developing capacity to assist users with implementing GAP information through collaboration. \\
\hline Coordination and collaboration with state and federal agencies \\
\hline Coordinate with State Landcover mapping programs. \\
\hline $\begin{array}{l}\text { Convey use of data to and through regional conservation partnerships like Joint Ventures, regional state agency } \\
\text { organizations, etc. }\end{array}$ \\
\hline Contacting local GIS users groups and making announcements through them \\
\hline Theme: Examples $(n=5)$ \\
\hline Specific examples of success \\
\hline Examples of usage \\
\hline Demonstration of various uses of GAP products and their accuracies or reliabilities, independently measured \\
\hline Showcasing applied research using GAP products. \\
\hline Examples of applications of GAP data. \\
\hline Theme: Don't know $(n=5)$ \\
\hline I don't know (2) \\
\hline Unsure \\
\hline I have no idea \\
\hline
\end{tabular}




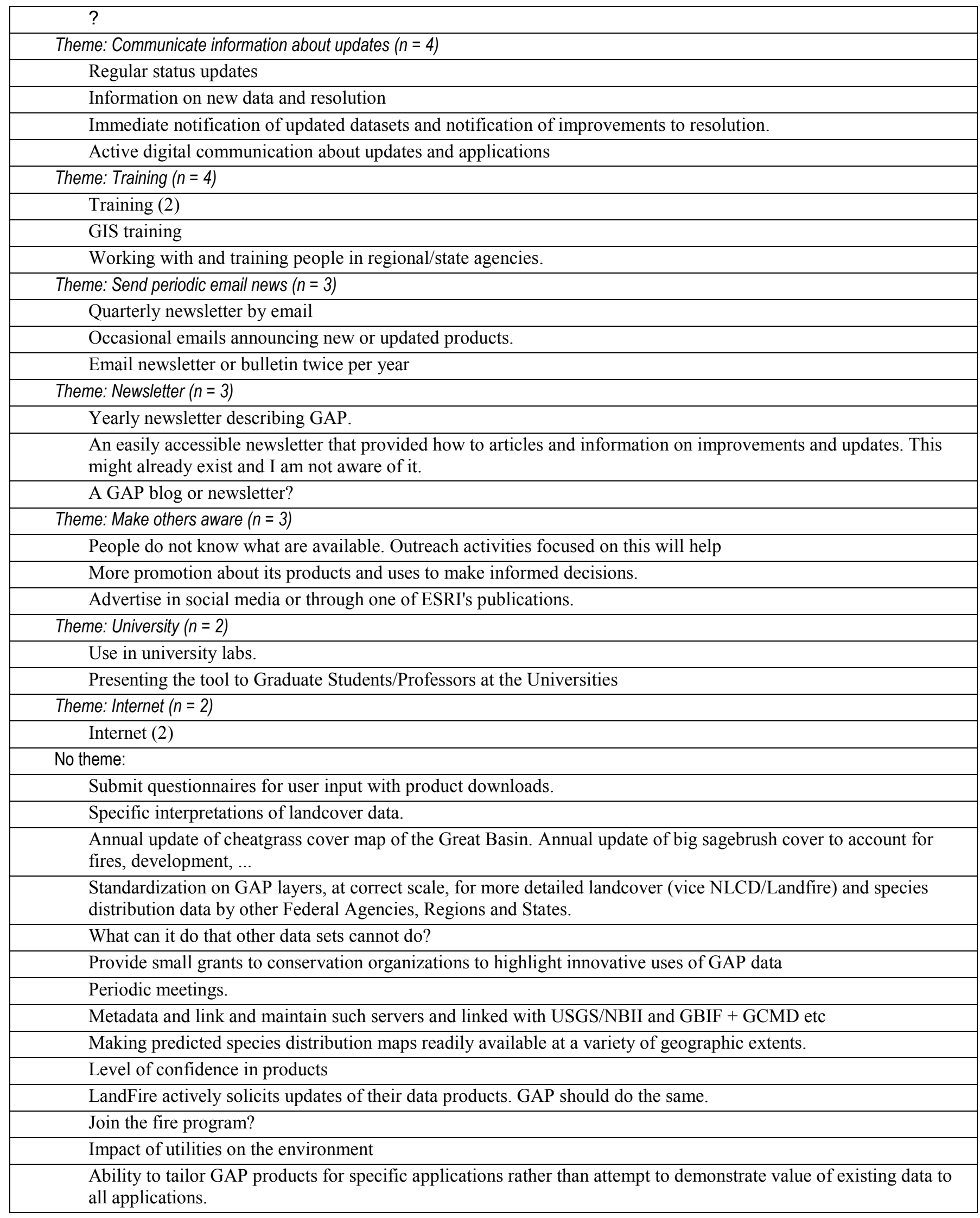




\begin{tabular}{|l|}
\hline Better data \\
\hline Information available at the state GIS portal \\
\hline How do I get it? \\
\hline Decision makers (Commissioners) do not know GAP exists. \\
\hline
\end{tabular}

Q178 Have you ever used information that you located in the GAP Bulletin publication? $(n=270)$.

\begin{tabular}{|l|c|}
\hline Response & Percent \\
\hline a. Yes & 20 \\
\hline b. No & $\mathbf{8 0}$ \\
\hline
\end{tabular}

If respondents answered "No" to this question, they were asked a follow-up question (Q179) and then directed to Q182. If respondents answered "Yes" to this question, they were asked Q180 and Q181 as follow-up questions.

Q179 Why haven't you used information from the GAP Bulletin publication? $(n=211)$

\begin{tabular}{|l|c|}
\hline Response & Percent \\
\hline a. I'm not familiar with the GAP Bulletin. & $\mathbf{7 9}$ \\
\hline b. The information provided is too narrow in focus to be of use to me. & 2 \\
\hline c. Never had an occasion to use information from the Bulletin. & 18 \\
\hline d. Other: [open-ended response] & 1 \\
\hline Theme: Not relevant (n= 2) & \\
\hline It is not relevant to my current work & \\
\hline It no longer relates to my job & \\
\hline No theme: & \\
\hline Is the Bulletin still published? & \\
\hline
\end{tabular}

Q180 How useful was the information that you located in the GAP Bulletin? ( $n=51$, average $=3$ )

\begin{tabular}{|c|c|c|c|}
\hline $\begin{array}{c}\text { a. Not at all useful } \\
(1)\end{array}$ & $\begin{array}{c}\text { b. Somewhat useful } \\
(\mathbf{2})\end{array}$ & $\begin{array}{c}\text { c. Moderately useful } \\
(3)\end{array}$ & $\begin{array}{c}\text { d. Very useful } \\
(4)\end{array}$ \\
\hline $2 \%$ & $\mathbf{4 3 \%}$ & $41 \%$ & $14 \%$ \\
\hline
\end{tabular}

Q181 How would you rate the quality of the GAP Bulletin as an information source? $(n=49$, average $=3)$

\begin{tabular}{|c|c|c|c|}
\hline $\begin{array}{c}\text { a. Poor } \\
(1)\end{array}$ & b. Fair & c. Good & d. Excellent \\
$(2)$ & $(3)$ & $6 \%$ \\
\hline
\end{tabular}

Q182 When was the last time you visited the GAP web site? $(n=270)$

\begin{tabular}{|l|c|}
\hline Response & Percent \\
\hline a. Never & 14 \\
\hline b. Within the last 4 months & 22 \\
\hline c. Within the last 5-8 months & 15 \\
\hline d. Within the last 9-12 months & 10 \\
\hline e. More than 1 year ago & $\mathbf{3 9}$ \\
\hline
\end{tabular}


Respondents who answered that they have never visited the GAP web site skipped Q183 and Q184 and went directly to the next section of questions beginning with Q185. Respondents who indicated they had ever visited the GAP web site were asked Q183 and Q184.

Q183 What was your purpose in visiting the site? $(n=225)$

\begin{tabular}{|l|c|}
\hline Response & Percent \\
\hline a. Obtain information & $\mathbf{5 1}$ \\
\hline b. Download data & 30 \\
\hline c. Use a web map service & 6 \\
\hline d. Use the Gap Ecosystem Data Explorer tool & 1 \\
\hline e. Find contact information & 5 \\
\hline f. Other: [open-ended response] & 8 \\
\hline Theme: Check for updates ( $n=4)$ & \\
\hline See what was new & \\
\hline See changes & \\
\hline Check for updates & \\
\hline Checking for new or updated information & \\
\hline Theme: Check availability of data ( $n=3)$ & \\
\hline To see what datasets were available & \\
\hline To see if the data I helped create were being served yet & \\
\hline See if Maryland was covered in a regional GAP project & \\
\hline Theme: Don't remember ( $=2$ ) & \\
\hline I forget & \\
\hline Don't remember, it was so long ago. & \\
\hline No theme: & \\
\hline Review GAP data prior to survey & \\
\hline Review draft models at request of GAP & \\
\hline Point a user to the site & \\
\hline Find out what it is & \\
\hline Check the accuracy of a specific distribution model & \\
\hline Looking for applications of the data & \\
\hline To obtain proper reference for California GAP program & \\
\hline & \\
\hline & \\
\hline & \\
\hline & \\
\hline & \\
\hline & \\
\hline & \\
\hline & \\
\hline & \\
\hline & \\
\hline & \\
\hline & \\
\hline & \\
\hline & \\
\hline & \\
\hline & \\
\hline & \\
\hline & \\
\hline & \\
\hline & \\
\hline & \\
\hline & \\
\hline
\end{tabular}

\section{Q184 Did your visit to the web site meet your needs? $(n=219)$}

Response

a. No

b. Yes, the visit met a few of my needs

c. Yes, the visit met most of my needs

d. Yes, the visit met all of my needs

\begin{tabular}{|c|c|}
\hline & Percent \\
\hline & 6 \\
\hline & 33 \\
\hline & 37 \\
\hline
\end{tabular}

\section{Reputation of GAP}

In this section of the survey, respondents were asked their opinions regarding the reputation of GAP and the data it produces. 
Q185 GAP is mostly unknown in the community of conservation professionals. $(n=256$, average $=4)$

\begin{tabular}{|c|c|c|c|c|}
\hline $\begin{array}{l}\text { a. Strongly disagree } \\
\text { (5) }\end{array}$ & $\begin{array}{l}\text { b. Somewhat disagree } \\
\text { (4) }\end{array}$ & $\begin{array}{l}\text { c. Neither agree nor } \\
\text { disagree } \\
\text { (3) }\end{array}$ & $\begin{array}{l}\text { d. Somewhat agree } \\
\text { (2) }\end{array}$ & $\begin{array}{c}\text { e. Strongly agree } \\
\text { (1) }\end{array}$ \\
\hline $26 \%$ & $36 \%$ & $21 \%$ & $14 \%$ & $3 \%$ \\
\hline
\end{tabular}

Q186 GAP is mostly unknown in the GIS user community. $(n=256$, average $=3)$

\begin{tabular}{|c|c|c|c|c|}
\hline $\begin{array}{l}\text { a. Strongly disagree } \\
\text { (5) }\end{array}$ & $\begin{array}{l}\text { b. Somewhat disagree } \\
\text { (4) }\end{array}$ & $\begin{array}{l}\text { c. Neither agree nor } \\
\text { disagree } \\
\text { (3) }\end{array}$ & $\begin{array}{c}\text { d. Somewhat agree } \\
\text { (2) }\end{array}$ & $\begin{array}{c}\text { e. Strongly agree } \\
\text { (1) }\end{array}$ \\
\hline $20 \%$ & $36 \%$ & $20 \%$ & $20 \%$ & $5 \%$ \\
\hline
\end{tabular}

Q187 The Gap Program has a reputation as being a credible source of data. ( $n=255$, average $=4$ )

\begin{tabular}{|c|c|c|c|c|}
\hline $\begin{array}{l}\text { a. Strongly disagree } \\
\text { (1) }\end{array}$ & $\begin{array}{l}\text { b. Somewhat disagree } \\
\text { (2) }\end{array}$ & $\begin{array}{l}\text { c. Neither agree nor } \\
\text { disagree } \\
\text { (3) }\end{array}$ & $\begin{array}{l}\text { d. Somewhat agree } \\
\text { (4) }\end{array}$ & $\begin{array}{l}\text { e. Strongly agree } \\
\text { (5) }\end{array}$ \\
\hline $1 \%$ & $8 \%$ & $29 \%$ & $49 \%$ & $13 \%$ \\
\hline
\end{tabular}

Q188 GAP has a unique niche in the biodiversity data it provides. $(n=255$, average $=4)$

\begin{tabular}{|c|c|c|c|c|}
\hline $\begin{array}{l}\text { a. Strongly disagree } \\
\text { (1) }\end{array}$ & $\begin{array}{c}\text { b. Somewhat disagree } \\
\text { (2) }\end{array}$ & $\begin{array}{l}\text { C. Neither agree nor } \\
\text { disagree } \\
\text { (3) }\end{array}$ & $\begin{array}{l}\text { d. Somewhat agree } \\
\text { (4) }\end{array}$ & $\begin{array}{l}\text { e. Strongly agree } \\
\text { (5) }\end{array}$ \\
\hline$<0.5 \%$ & $8 \%$ & $24 \%$ & $47 \%$ & $22 \%$ \\
\hline
\end{tabular}

Q189 GAP is losing ground to competing organizations that produce similar data. ( $n=254$, average $=3$ )

\begin{tabular}{|c|c|c|c|c|}
\hline $\begin{array}{l}\text { a. Strongly disagree } \\
\text { (5) }\end{array}$ & $\begin{array}{l}\text { b. Somewhat disagree } \\
\text { (4) }\end{array}$ & $\begin{array}{l}\text { c. Neither agree nor } \\
\text { disagree } \\
\text { (3) }\end{array}$ & $\begin{array}{l}\text { d. Somewhat agree } \\
\text { (2) }\end{array}$ & $\begin{array}{l}\text { e. Strongly agree } \\
\text { (1) }\end{array}$ \\
\hline $4 \%$ & $10 \%$ & $53 \%$ & $26 \%$ & $8 \%$ \\
\hline
\end{tabular}

Q190 Do the GAP program and its data have a national reputation? $(n=256)$

\begin{tabular}{|l|c|}
\hline Response & Percent \\
\hline a. GAP is not known & 1 \\
\hline b. Known to a few individuals nation-wide & 3 \\
\hline c. Known to some individuals nation-wide & 21 \\
\hline d. Known to many individuals nation-wide & 29 \\
\hline e. Well known nation-wide & 15 \\
\hline f. Cannot judge & $\mathbf{3 1}$ \\
\hline
\end{tabular}

Q191 Do the GAP program and its data have a state-level reputation? $(n=258)$

\begin{tabular}{|l|c|}
\hline Response & Percent \\
\hline a. GAP is not known & $<0.5$ \\
\hline b. Known to a few individuals state-wide & 11 \\
\hline c. Known to some individuals state-wide & 25 \\
\hline d. Known to many individuals state-wide & $\mathbf{2 9}$ \\
\hline e. Well known state-wide & 18 \\
\hline f. Cannot judge & 17 \\
\hline
\end{tabular}


Q192 Do the GAP program and its data have a municipal/county level reputation? $(n=258)$

\begin{tabular}{|l|c|}
\hline Response & Percent \\
\hline a. GAP is not known & 15 \\
\hline b. Known to a few individuals at the level of cities and counties & 19 \\
\hline c. Known to some individuals at the level of cities and counties & 16 \\
\hline d. Known to many individuals at the level of cities and counties & 5 \\
\hline e. Well known at the level of cities and counties & 2 \\
\hline f. Cannot judge & $\mathbf{4 3}$ \\
\hline
\end{tabular}

Q193 In your opinion, approximately what percent of people who could potentially use GAP data actually know about GAP and the data it provides? $(n=246)$

\begin{tabular}{|l|c|}
\hline Response & Percent \\
\hline a. Less than $10 \%$ & 11 \\
\hline b. Between 10 and $25 \%$ & 27 \\
\hline c. Between $\mathbf{2 6}$ and $\mathbf{5 0 \%}$ & $\mathbf{3 2}$ \\
\hline d. Between 51 and $75 \%$ & 22 \\
\hline e. Between 76 and $100 \%$ & 8 \\
\hline
\end{tabular}

Q194 How strongly would you recommend use of GAP data to others, assuming they had an appropriate need for the type of data that GAP provides? $(n=253)$

\begin{tabular}{|l|c|}
\hline Response & Percent \\
\hline a. I would give my strongest recommendation to someone considering use of GAP data. & 12 \\
\hline b. I would recommend use of GAP data. & 77 \\
\hline c. I would hesitate to recommend use of GAP data. & 9 \\
\hline d. I would caution against use of GAP data. & 3 \\
\hline e. I would strongly urge others not to use GAP data. & $<0.5$ \\
\hline
\end{tabular}

Q195 Have you recommended use of GAP data to someone else? $(n=265)$

\begin{tabular}{|c|c|c|}
\hline \multicolumn{2}{|l|}{ Response } & Percent \\
\hline \multicolumn{2}{|l|}{ a. Yes } & 79 \\
\hline \multicolumn{2}{|c|}{$\begin{array}{l}\text { Q196 After you made the recommendation, did you receive feedback from the person to whom you } \\
\text { recommended use of GAP data? }(n=203)\end{array}$} & \\
\hline a. No, no feedback & $75 \%$ & \\
\hline b. Yes, positive feedback & $22 \%$ & \\
\hline c. Yes, negative feedback & $3 \%$ & \\
\hline \multicolumn{2}{|l|}{ b. No } & 22 \\
\hline \multicolumn{2}{|c|}{ Q197 What is the main reason why you have not recommended GAP data to someone else? $(n=56)$} & \\
\hline a. No appropriate opportunity has presented itself. & $\mathbf{5 7 \%}$ & \\
\hline b. I have reservations about the accuracy of the data. & $9 \%$ & \\
\hline c. I have reservations that the data are outdated. & $7 \%$ & \\
\hline d. I had difficulty in using GAP data myself. & $4 \%$ & \\
\hline e. GAP data are missing relevant content. & $7 \%$ & \\
\hline f. Other: [open-ended response] & $16 \%$ & \\
\hline \multicolumn{2}{|l|}{ Theme: Lack of familiarity $(n=3)$} & \\
\hline Unfamiliarity with gap data other than the protected lands layer & & \\
\hline
\end{tabular}




\begin{tabular}{|c|l|}
\hline I don't use it. Not familiar enough & \\
\hline Don't know enough about it & \\
\hline Theme: Resolution ( $n=2)$ & \\
\hline $\begin{array}{c}\text { Scale of resolution too coarse, neither accuracy nor methodology } \\
\text { not fully given in the past }\end{array}$ & \\
\hline Doesn't meet resolution needs. & \\
\hline Theme: Don't use GAP $(n=2)$ & \\
\hline I don't use GAP & \\
\hline I do not use GAP data and do not have an opinion & \\
\hline No theme: & \\
\hline No reason to recommend & \\
\hline I mostly use other data & \\
\hline
\end{tabular}

\section{Goals and Objective of GAP}

In this section, respondents were asked to assess how well GAP is meeting its goals and objectives. This is the last section of survey questions.

Q198 In your experience and opinion, in what way are GAP datasets most frequently used? $(n=251)$

\begin{tabular}{|l|c|}
\hline Response & Percent \\
\hline a. To solve policy issues such as land use issues relating to conservation & 14 \\
\hline $\begin{array}{l}\text { b. To provide decisionmakers with knowledge about topics such as conservation concepts, models or } \\
\text { priorities }\end{array}$ & $\mathbf{3 8}$ \\
\hline $\begin{array}{l}\text { c. To legitimize decisions, such as decisions about land use and land protection, made on the basis of other } \\
\text { information }\end{array}$ & 21 \\
\hline d. To conduct academic research to fulfill course or degree requirements or for the purpose of publication & 14 \\
\hline e. To conduct applied research that is conducted for some reason other than to inform conservation decisionmaking & 14 \\
\hline
\end{tabular}

Q199 In your experience and opinion, what is the most appropriate use for GAP datasets? $(n=251)$

\begin{tabular}{|l|c|}
\hline Response & Percent \\
\hline a. To solve policy issues such as land use issues relating to conservation & 15 \\
\hline $\begin{array}{l}\text { b. To provide decisionmakers with knowledge about topics such as conservation concepts, models or } \\
\text { priorities. }\end{array}$ & $\mathbf{5 3}$ \\
\hline $\begin{array}{l}\text { c. To legitimize decisions, such as decisions about land use and land protection, made on the basis of other } \\
\text { information. }\end{array}$ & 20 \\
\hline d. To conduct academic research to fulfill course or degree requirements or for the purpose of publication. & 4 \\
\hline e. To conduct applied research that is conducted for some reason other than to inform conservation decisionmaking. & 8 \\
\hline
\end{tabular}

Q200 Please rate how helpful GAP data are or could be in addressing the following issues:

\begin{tabular}{|l|c|c|c|c|c|c|}
\hline & $\begin{array}{c}\text { Cannot judge } \\
\text { (no value, } \\
\text { excluded } \\
\text { from } \\
\text { average) }\end{array}$ & $\begin{array}{c}\text { Not at all } \\
\text { helpful } \\
(1)\end{array}$ & $\begin{array}{c}\text { Slightly } \\
\text { helpful } \\
(2)\end{array}$ & $\begin{array}{c}\text { Moderately } \\
\text { helpful } \\
(3)\end{array}$ & Helpful & Very helpful \\
\hline $\begin{array}{l}\text { Habitation conversion/loss } \\
(n=245, \text { average }=4)\end{array}$ & $11 \%$ & $2 \%$ & $8 \%$ & $15 \%$ & $\mathbf{4 0 \%}$ & $24 \%$ \\
\hline $\begin{array}{l}\text { Habitat conservation } \\
(n=242, \text { average }=4)\end{array}$ & $9 \%$ & $1 \%$ & $8 \%$ & $13 \%$ & $\mathbf{4 2 \%}$ & $27 \%$ \\
\hline Invasive/exotic species & $20 \%$ & $12 \%$ & $\mathbf{2 3 \%}$ & $13 \%$ & $\mathbf{2 3 \%}$ & $9 \%$ \\
\hline
\end{tabular}




\begin{tabular}{|c|c|c|c|c|c|c|}
\hline$(n=239$, average $=3)$ & & & & & & \\
\hline $\begin{array}{l}\text { Changes in hydrological } \\
\text { processes/Hydrologic } \\
\text { restoration } \\
(n=243 \text {, average }=3)\end{array}$ & $33 \%$ & $12 \%$ & $24 \%$ & $18 \%$ & $10 \%$ & $4 \%$ \\
\hline $\begin{array}{l}\text { Pollution } \\
(n=242, \text { average }=2)\end{array}$ & $38 \%$ & $21 \%$ & $20 \%$ & $15 \%$ & $5 \%$ & $2 \%$ \\
\hline $\begin{array}{l}\text { Fire suppression } \\
(n=243, \text { average }=3)\end{array}$ & $28 \%$ & $7 \%$ & $23 \%$ & $18 \%$ & $21 \%$ & $3 \%$ \\
\hline $\begin{array}{l}\text { Disturbance caused by } \\
\text { transportation/ infrastructure } \\
\text { development } \\
(n=241 \text {, average }=3)\end{array}$ & $18 \%$ & $3 \%$ & $20 \%$ & $22 \%$ & $29 \%$ & $8 \%$ \\
\hline $\begin{array}{l}\text { Consumptive use of biological } \\
\text { resources } \\
(n=241 \text {, average }=3)\end{array}$ & $25 \%$ & $10 \%$ & $22 \%$ & $17 \%$ & $23 \%$ & $3 \%$ \\
\hline $\begin{array}{l}\text { Improper forest management } \\
(n=237, \text { average }=3)\end{array}$ & $29 \%$ & $10 \%$ & $20 \%$ & $18 \%$ & $19 \%$ & $4 \%$ \\
\hline $\begin{array}{l}\text { Lack of knowledge about } \\
\text { species } \\
(n=239 \text {, average }=3)\end{array}$ & $18 \%$ & $4 \%$ & $18 \%$ & $19 \%$ & $30 \%$ & $12 \%$ \\
\hline $\begin{array}{l}\text { Climate change } \\
(n=238, \text { average }=3)\end{array}$ & $23 \%$ & $8 \%$ & $15 \%$ & $18 \%$ & $28 \%$ & $8 \%$ \\
\hline $\begin{array}{l}\text { Loss of natural community } \\
\text { integrity } \\
(n=241 \text {, average }=3)\end{array}$ & $18 \%$ & $5 \%$ & $15 \%$ & $22 \%$ & $29 \%$ & $12 \%$ \\
\hline $\begin{array}{l}\text { Degradation of migration } \\
\text { corridors/routes } \\
(n=238, \text { average }=3)\end{array}$ & $17 \%$ & $3 \%$ & $13 \%$ & $21 \%$ & $31 \%$ & $14 \%$ \\
\hline $\begin{array}{l}\text { Destructive resource } \\
\text { harvesting } \\
(n=236 \text {, average }=3)\end{array}$ & $25 \%$ & $7 \%$ & $21 \%$ & $21 \%$ & $23 \%$ & $4 \%$ \\
\hline $\begin{array}{l}\text { Non-consumptive use of } \\
\text { resources } \\
(n=238 \text {, average }=3)\end{array}$ & $32 \%$ & $14 \%$ & $22 \%$ & $18 \%$ & $12 \%$ & $2 \%$ \\
\hline $\begin{array}{l}\text { Research on species } \\
(n=238, \text { average }=3)\end{array}$ & $16 \%$ & $4 \%$ & $15 \%$ & $22 \%$ & $28 \%$ & $16 \%$ \\
\hline $\begin{array}{l}\text { Private land conservation } \\
(n=236, \text { average }=4)\end{array}$ & $13 \%$ & $4 \%$ & $10 \%$ & $25 \%$ & $36 \%$ & $13 \%$ \\
\hline $\begin{array}{l}\text { Restoration of Species of } \\
\text { greatest conservation need } \\
(\mathrm{SGCN}) \text { and habitats } \\
(n=237, \text { average }=4)\end{array}$ & $17 \%$ & $5 \%$ & $9 \%$ & $21 \%$ & $35 \%$ & $14 \%$ \\
\hline $\begin{array}{l}\text { Species conservation and/or } \\
\text { management } \\
(n=241 \text {, average }=4)\end{array}$ & $10 \%$ & $1 \%$ & $8 \%$ & $21 \%$ & $40 \%$ & $19 \%$ \\
\hline $\begin{array}{l}\text { Research on habitats } \\
(n=239, \text { average }=4)\end{array}$ & $11 \%$ & $2 \%$ & $10 \%$ & $17 \%$ & $40 \%$ & $20 \%$ \\
\hline $\begin{array}{l}\text { Public lands conservation } \\
(n=238, \text { average }=4)\end{array}$ & $8 \%$ & $2 \%$ & $8 \%$ & $16 \%$ & $42 \%$ & $24 \%$ \\
\hline
\end{tabular}


Q200a Other current biological conservation issue(s) that GAP data could be helpful in addressing? [open-ended response] $(n=20)$

\begin{tabular}{|l|}
\hline Response \\
\hline Theme: Don't know ( $n=3)$ \\
\hline Not sure of any to add. \\
\hline I do not know for now. \\
\hline I am not a user to be able to judge the product; would like to learn about it and become a user however. \\
\hline Theme: Aquatic issues ( $n=2$ ) \\
\hline Fish habitat issues if aquatic gap data was more available. \\
\hline Aquatic gaps still needs more work. My comments mainly address aquatic gap. \\
\hline No theme: \\
\hline Wetland inventory \\
\hline $\begin{array}{l}\text { The above question is not well worded because it says ARE or COULD BE. All of the above COULD be helpful, if } \\
\text { the products were developed and disseminated in a consistent, reliable manner }\end{array}$ \\
\hline Prioritizing integrated conservation and restoration \\
\hline $\begin{array}{l}\text { Landscape scale conservation planning is the most relevant appliation of gap data historically. Inclusion of } \\
\text { additional data sets - could extend the application to other issues. }\end{array}$ \\
\hline Landscape Change \\
\hline $\begin{array}{l}\text { Integrating biodiversity and wildlife habitat values with the provision and quality of closely related ecosystem } \\
\text { services - and bringing that combined information into assessment and planning decisions; mostly at ecoregion } \\
\text { scales. }\end{array}$ \\
\hline Increases in impervious surfaces \\
\hline Forest health and insect outbreaks \\
\hline Forecasting and Backcasting + Research and Monitoring Designs \\
\hline Fire issues, water issues (drought) \\
\hline Endangered species/ecosystem management \\
\hline Ecological patch analysis \\
\hline Conversion of grasslands regionally \\
\hline Urban-wildland dynamics \\
\hline None \\
\hline
\end{tabular}

If respondents selected option "Not at all helpful" for any of the topics listed in Q200, they were directed to Q201; otherwise, respondents were directed to Q202.

Q201 You indicated that GAP data are not helpful for one or more of the named issues. Why are GAP data not helpful in addressing those issues? $(n=93)$

\begin{tabular}{|l|c|}
\hline Response & Percent \\
\hline a. Data quality & 16 \\
\hline b. Data availability, needed data are not available & 16 \\
\hline c. Data are available but not in needed format or spatial resolution & 18 \\
\hline d. Data are not helpful, because of limited awareness about GAP data & 3 \\
\hline e. GAP data are just not relevant to these issues & $\mathbf{3 1}$ \\
\hline f. Other: [open-ended response] & 15 \\
\hline$\quad$ Theme: Outdated data $(n=3)$ & \\
\hline The data is too old & \\
\hline GAP maps are not updated through time & \\
\hline Data are outdated & \\
\hline
\end{tabular}




\begin{tabular}{|l|l|}
\hline Theme: Issues with land-cover data $(n=3)$ & \\
\hline Landcover classes too vague. & \\
\hline Lack of condition/quality of veg & \\
\hline Data do not represent temporal trends in land cover. & \\
\hline No theme: & \\
\hline Scale. NAIP + vegetation inventory/monitoring is more useful for most of my needs. & \\
\hline No accuracy assessment & \\
\hline $\begin{array}{l}\text { I am not aware of migration data being available, although the land cover data can probably be } \\
\text { used to address this }\end{array}$ & \\
\hline $\begin{array}{l}\text { Data are not updated enough to monitor change or change is due to better data but not new } \\
\text { conservation }\end{array}$ & \\
\hline Combination of quality and availability & \\
\hline Alternative data sources better and more available & \\
\hline
\end{tabular}

Q202 The information products that can be derived from GAP data are compatible with existing policy making processes and models. $(n=241$, average $=4)$

\begin{tabular}{|c|c|c|c|c|}
\hline $\begin{array}{l}\text { a. Strongly disagree } \\
\text { (1) }\end{array}$ & $\begin{array}{l}\text { b. Somewhat disagree } \\
\text { (2) }\end{array}$ & $\begin{array}{l}\text { c. Neither agree nor } \\
\text { disagree } \\
\text { (3) }\end{array}$ & $\begin{array}{l}\text { d. Somewhat agree } \\
\text { (4) }\end{array}$ & $\begin{array}{l}\text { e. Strongly agree } \\
\text { (5) }\end{array}$ \\
\hline $1 \%$ & $3 \%$ & $38 \%$ & $44 \%$ & $14 \%$ \\
\hline
\end{tabular}

Q203 GAP data are relevant to currently pending decisions that relate to the conservation of biodiversity. $(n=240$, average $\mathbf{= 1}$ )

\begin{tabular}{|c|c|c|c|c|}
\hline a. Strongly disagree & b. Somewhat disagree & $\begin{array}{c}\text { c. Neither agree nor } \\
\text { disagree } \\
(3)\end{array}$ & $\begin{array}{c}\text { d. Somewhat agree } \\
\text { e. Strongly agree }\end{array}$ & $(5)$ \\
\hline$(1)$ & $(2)$ & $23 \%$ & $\mathbf{5 3 \%}$ & $20 \%$ \\
\hline
\end{tabular}

Q204 I believe individuals who are in positions to make decisions about conservation of biodiversity would be open to considering the type of information products that could be produced using GAP data. $(n=240$, average $=4)$

\begin{tabular}{|c|c|c|c|c|}
\hline $\begin{array}{l}\text { a. Strongly disagree } \\
\text { (1) }\end{array}$ & $\begin{array}{l}\text { b. Somewhat disagree } \\
\text { (2) }\end{array}$ & $\begin{array}{l}\text { c. Neither agree nor } \\
\text { disagree } \\
\text { (3) }\end{array}$ & $\begin{array}{l}\text { d. Somewhat agree } \\
\text { (4) }\end{array}$ & $\begin{array}{c}\text { e. Strongly agree } \\
\text { (5) }\end{array}$ \\
\hline$<0.5 \%$ & $3 \%$ & $15 \%$ & $56 \%$ & $26 \%$ \\
\hline
\end{tabular}

Q205 To what extent has GAP met its objective to assess the geographic extent of biodiversity in the United States? $(n=242)$

\begin{tabular}{|l|c|}
\hline Response & Percent \\
\hline a. GAP has done nothing to meet this objective. & \\
\hline b. GAP is less than halfway to meeting this objective. & 11 \\
\hline c. GAP is about halfway to meeting this objective. & 12 \\
\hline d. GAP is more than halfway to meeting this objective. & 27 \\
\hline e. GAP has completely met this objective. & 5 \\
\hline f. I don't have enough knowledge to make this judgment. & $\mathbf{4 4}$ \\
\hline
\end{tabular}




\begin{tabular}{|l|c|}
\hline Response & Percent \\
\hline a. GAP has done nothing to meet this objective. & $<0.5$ \\
\hline b. GAP is less than halfway to meeting this objective. & 11 \\
\hline c. GAP is about halfway to meeting this objective. & 13 \\
\hline d. GAP is more than halfway to meeting this objective. & 26 \\
\hline e. GAP has completely met this objective. & 7 \\
\hline f. I don't have enough knowledge to make this judgment. & $\mathbf{4 2}$ \\
\hline
\end{tabular}

Q207 How would you grade the current performance of GAP on building institutional cooperation in the application of its information to state and regional management activities? $(n=242$, average $=3)$

\begin{tabular}{|c|c|c|c|c|c|}
\hline a. A & b. B & C. C & d. D & e. F & $\begin{array}{c}\text { f. I don't have enough } \\
\text { knowledge to grade this } \\
\text { item } \\
\text { (no value) }\end{array}$ \\
\hline $9 \%$ & $(3)$ & $(2)$ & $(1)$ & $(0)$ & $\mathbf{4 4 \%}$ \\
\hline
\end{tabular}

Q208 How would you grade the current performance of GAP on providing information to the public and to those organizations charged with natural resource research, policy, planning, and management? $(n=241$, average $=2)$

\begin{tabular}{|c|c|c|c|c|c|}
\hline a. A & b. B & C. C & d. D & e. F & $\begin{array}{c}\text { f. I don't have enough } \\
\text { knowledge to grade this } \\
\text { item } \\
\text { (no value) }\end{array}$ \\
\hline$(4)$ & $(3)$ & $(2)$ & $(1)$ & $(0)$ & $\mathbf{3 7 \%}$ \\
\hline $9 \%$ & $22 \%$ & $23 \%$ & $8 \%$ & $2 \%$ & \\
\hline
\end{tabular}

\section{General Comment}

Q209 End question: Would you like to provide any other comments about the data provided by the Gap Analysis Program? [open-ended response] $(n=70)$

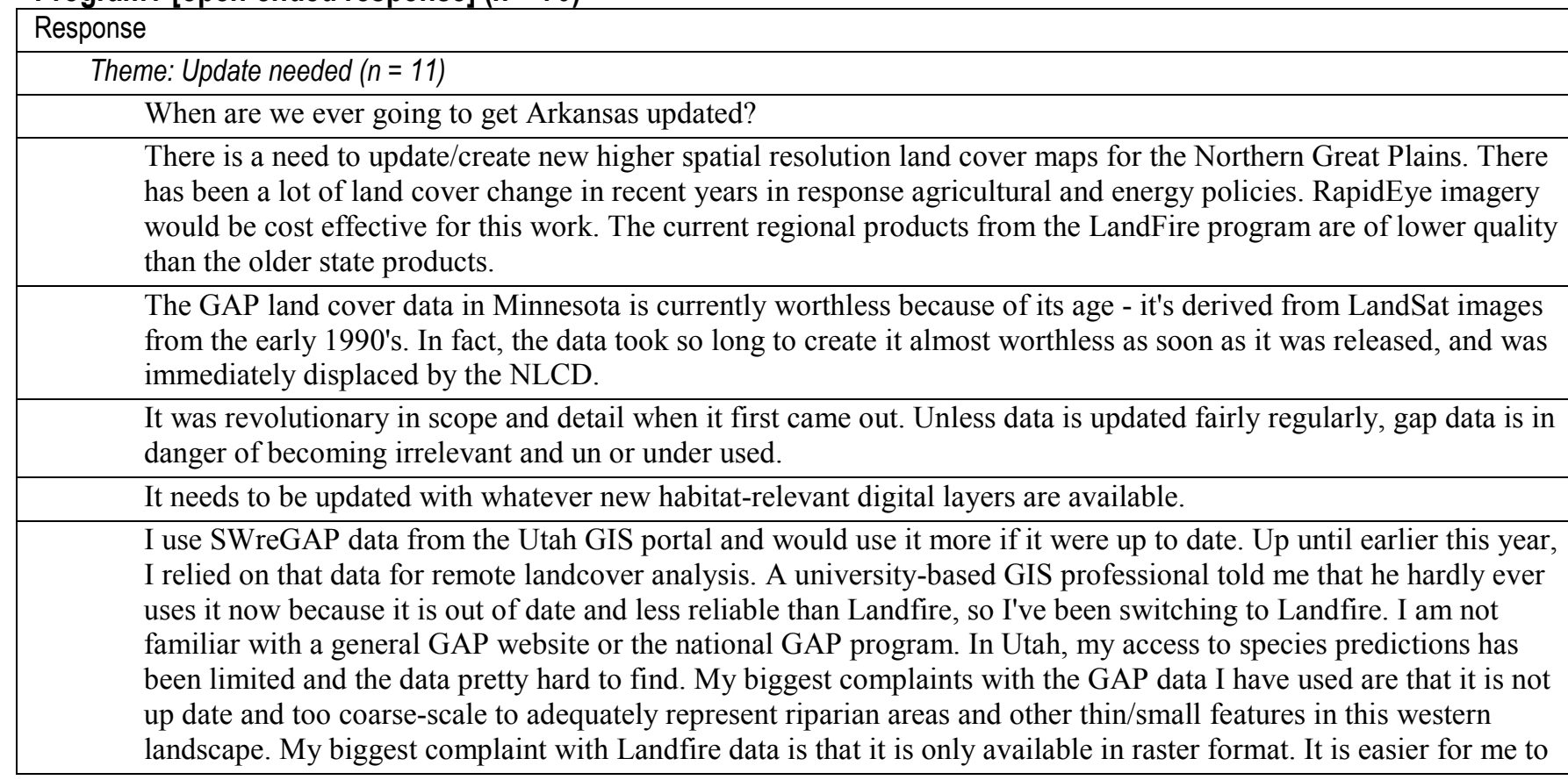




\begin{tabular}{|c|}
\hline work with polygons than with raster pixels. \\
\hline I think the GAP data is great, just too old in our state, which is rapidly changing. \\
\hline $\begin{array}{l}\text { GAP data are very valuable to Minnesota's Coastal management program. It would be great to see a stronger } \\
\text { relationship with NOAA C-CAP program and an update to land cover and land stewardship data. }\end{array}$ \\
\hline $\begin{array}{l}\text { GAP data are useful, but in MN they are } 20 \text { years out of date. They are still useful in the boreal part of the state; not } \\
\text { so much elsewhere. Classification reliability at Level } 4 \text { is generally poor, which is why I almost always aggregate } \\
\text { and reclass at Level 3. }\end{array}$ \\
\hline Almost all my responses reflect one basic issue: the Midwest needs an updated regional GAP. \\
\hline $\begin{array}{l}\text { An update cycle would allow correcting spatial and attribute errors as well as improving currency. Stewardship } \\
\text { changes faster than landcover and is easier to update. }\end{array}$ \\
\hline Theme: No comments $(n=10)$ \\
\hline None \\
\hline No (9) \\
\hline Theme: What would be helpful $(n=8)$ \\
\hline $\begin{array}{l}\text { The most common critique I hear about Gap is that the data are not accurate enough at high resolution. Personally, I } \\
\text { understand the limitations of the input data and the appropriate scale for most datasets, but many end-users fail to } \\
\text { appreciate this. The scale mismatch issues are greatest in the land cover layer - especially with aquatic features. Gap } \\
\text { could do a better job of explaining this problem to end users. }\end{array}$ \\
\hline $\begin{array}{l}\text { We use GAP for two things: land use change and species distribution models. I really want to see GAP gain more } \\
\text { detail in each. The species models are created on a regional scale and they are are very useful at that scale, but at the } \\
\text { local scale, they are less useful. It would be fantastic if additional information could be brought forward to merge } \\
\text { GAP models with more current information (about habitat) and observations. }\end{array}$ \\
\hline $\begin{array}{l}\text { We need maps that show stand age or seral stage. We need higher resolution species distribution maps based on } \\
\text { models that use stand age or seral stage as predictor variables. Models for mapping species distributions should also } \\
\text { use minimum area requirements of a species as predictors variables. }\end{array}$ \\
\hline $\begin{array}{l}\text { Most program efforts are on data development and provision, but not enough focuses on analysis. Much more } \\
\text { valuable attention would come to the program if there was greater emphasis placed on analysis and drawing helpful } \\
\text { conclusions; aim at national scale assessment (not planning, assessment) and bring in your cooperator community to } \\
\text { prioritize and carry off the analyses under the Gap Program flag. The main results of national "gap analysis" (in its } \\
\text { many forms) should be common knowledge in Washington DC; and to regional leadership of federal land } \\
\text { managers, and within leaders of state agencies. }\end{array}$ \\
\hline More species please \\
\hline $\begin{array}{l}\text { Another protected area dataset is the one put out by CBI (http://www.protectedlands.net). I know they are similar, } \\
\text { but there are some differences. It is very confusing about what dataset I should use and what exactly is the } \\
\text { difference between them. I would like to see the USGS put out some information on the differences, and the } \\
\text { appropriates uses of each. }\end{array}$ \\
\hline $\begin{array}{l}\text { My employer put money into developing the state GAP program many years ago and I have forgotten all about it } \\
\text { because I did not have direct access to the program. Our GIS folks need to inform biological staff that it is available } \\
\text { and help us get access to it. }\end{array}$ \\
\hline $\begin{array}{l}\text { GAP needs to serve people on a state by state basis. Workshops in each state would be good. Feds usually ignore } \\
\text { Arkansas. The program needs to focus more on aquatic gap. It it too terrestrial oriented. }\end{array}$ \\
\hline Theme: Comment about the survey $(n=8)$ \\
\hline $\begin{array}{l}\text { This survey would have been better if there had been fewer questions about the "best" or most use of data, since we } \\
\text { use species data almost as much as Land Cover data. }\end{array}$ \\
\hline This survey was way too long to provide meaningful information. \\
\hline This survey was too long. Suggest streamlining. \\
\hline $\begin{array}{l}\text { This survey may be meaningless. It appears to be directed solely at terrestrial issues, and most of my use has been } \\
\text { stream characteristics models and fish mussel and crayfish distribution models for Missouri streams. }\end{array}$ \\
\hline My use of GAP was old, so most answers for current GAP issues were guesses. \\
\hline I am not a user, hence, was unable to comment effectively on many questions. Perhaps some changes to the \\
\hline
\end{tabular}




\begin{tabular}{|c|}
\hline $\begin{array}{l}\text { beginning of the survey can help identify that point. I am merely here to learn about GAP and hopefully become a } \\
\text { user at somepoint. }\end{array}$ \\
\hline $\begin{array}{l}\text { I am a biologist, not a GIS specialist, so many questions were not appropriate. For GIS specialist in the Kansas } \\
\text { Biological Survey, contact [personal information deleted] This questionaire is too long. }\end{array}$ \\
\hline $\begin{array}{l}\text { Gap has several products, and this survey does not adequately separate out those products in the questions. The } \\
\text { species distribution maps tend to be less credible than the pad us maps, in my view. There was no way to make this } \\
\text { statement in the survey. }\end{array}$ \\
\hline Theme: Outreach/cooperation $(n=5)$ \\
\hline $\begin{array}{l}\text { There has always been a weak connection between those who compile GAP data and those who could use it for } \\
\text { conservation decisions. The program has failed to invest in sufficient outreach and development of synthesized } \\
\text { information products that serve a broad audience. The program had a much higher profile in the early 90s than it } \\
\text { does now, as it was a very early GIS product. }\end{array}$ \\
\hline $\begin{array}{l}\text { It is a wonderful, ambitious program that has probably taken on too much with too little resources. GAP needs to } \\
\text { become more cooperative, less defensive and turfy, and reach out more to academics, practitioners, and NGOs. }\end{array}$ \\
\hline $\begin{array}{l}\text { I would like to know more of how to use the GAP tools in Puerto Rico. Little is known about these tools. Present } \\
\text { GAP to the university professionals and other personnel at the island. }\end{array}$ \\
\hline $\begin{array}{l}\text { I think you need to get the program out there and sell it. You need to market to OFWIM, NSGIC and others. You } \\
\text { should build collaborations with state and local agencies to build and use GAP data. }\end{array}$ \\
\hline $\begin{array}{l}\text { I think there just needs to be more marketing, education and training on GAP. I think it is useful, but it previously } \\
\text { had a reputuation of not being so good. }\end{array}$ \\
\hline Theme: Aquatic data $(n=4)$ \\
\hline $\begin{array}{l}\text { I considered both the terrestrial and aquatic gap projects when responding to all of these questions but based on the } \\
\text { definition of multiregion projects it was obvious that these questions where specifically directed at the terrestrial } \\
\text { gap effort and ignored the aquatic component. }\end{array}$ \\
\hline $\begin{array}{l}\text { I am really only familiar with the Great Lakes Aquatic GAP project, so many of the questions were not really } \\
\text { relevant. }\end{array}$ \\
\hline Begin more fish and fisheries habitat data online. \\
\hline $\begin{array}{l}\text { It is a great resource but more investment needs to be made and people need to use it more than it is being used. We } \\
\text { need to do more for the aquatic and terrestrial GAP interfaces. }\end{array}$ \\
\hline Theme: Comments about errors in or accuracy of data $(n=4)$ \\
\hline $\begin{array}{l}\text { Please provide a way for the land cover datasets to be updated, so we can correct errors. This is, I realize, easier said } \\
\text { than done, but it can be done, particularly with the advent of GPS cameras. One photo says a lot. }\end{array}$ \\
\hline $\begin{array}{l}\text { My experience has been that, in general, GAP land cover and species distribution maps contain too many errors for } \\
\text { them to be relied upon, except as ancillary data when more accurate site-specific data are lacking. }\end{array}$ \\
\hline $\begin{array}{l}\text { Part of the discussions our office has is in the accuracy of the data and the resolution of the data used in land } \\
\text { management. Many have the perception that GAP data is too coarse for our needs. }\end{array}$ \\
\hline $\begin{array}{l}\text { I haven't been very involved in Gap since the original Gap analyses back in the 90s (I was a developer of Gap data). } \\
\text { My sense now is that Gap has addressed the issue of resolution, but still suffers from a real or perceived lack of } \\
\text { accuracy, especially with land cover mapping. It's not that the methods used aren't appropriate, but that accurately } \\
\text { mapping huge regions or even states is very very difficult at the level of accuracy needed by local-scale land } \\
\text { managers. As you know, it's an old problem. }\end{array}$ \\
\hline Theme: Timeliness $(n=4)$ \\
\hline $\begin{array}{l}\text { Probably my biggest problem, answering these questions relates to my extensive use and moderately high } \\
\text { satisfaction with the } 1997 \text { products for Washington State and the more problematic experiences with the more } \\
\text { recent effort which has produced some products that appear to be no better, in some ways worse than what was } \\
\text { produced in 1997, a significant disappointment. The more recent products seem to have taken an inordinately long } \\
\text { time to be completed and were not available when I had a critical need for them. }\end{array}$ \\
\hline $\begin{array}{l}\text { In many places, this survey asked questions that were difficult to fully answer with the allowed choices. Ultimately, } \\
\text { I believe the primary downfall of GAP is the inability to provide more timely and accurate data - primarily land } \\
\text { cover. This isn't just a fault of GAP (NLCD, Landfire also have the same issue). Until steps are made to correct this, } \\
\text { the same complaints and issues will continue to arise. }\end{array}$ \\
\hline
\end{tabular}




\begin{tabular}{|c|}
\hline $\begin{array}{l}\text { I understand that it's a long and complicated process to create the vegetation maps, but if there's anyway to decrease } \\
\text { the time lag between image acquisition and mapping that would be helpful. Also, a suite of products related to } \\
\text { habitat quality and/or invasion by exotic species would be super helpful. }\end{array}$ \\
\hline $\begin{array}{l}\text { I like the land use land cover GAP data set, however it should not take } 10 \text { years to develop new data sets. The } \\
\text { imagery is completely out of date by the time the product is released. }\end{array}$ \\
\hline Theme: Respondent's background or perspective $(n=4)$ \\
\hline I was part of my state's GAP team and know how the data was collected and integrated into the data layers. \\
\hline $\begin{array}{l}\text { I was envolved with Gap Analysis over } 20 \text { years. I currently teach in Portugal and GAP data is not available for this } \\
\text { area }\end{array}$ \\
\hline $\begin{array}{l}\text { I apologize for not answering all your questions. I hired consultants who used Gap data to create a regional GIS } \\
\text { land cover map for me. I have never used the data myself, so felt unprepared to answer many questions. Having that } \\
\text { data enabled us to promote and successfully implement local zoning policies leading to the conservation of } 90,000 \\
\text { riparian acres in metropolitan Kansas city. I am supportive of strong national efforts to develop and use data for the } \\
\text { variety of purposes outlined in this survey. I am not experienced enough with the data to evaluate how well it has } \\
\text { served those purposes in the past. }\end{array}$ \\
\hline $\begin{array}{l}\text { FYI. I do not use GAP data on a frequent basis. I've used GAP data for species/habitat conservation planning. And I } \\
\text { am not that familiar with the uses of GAP data. Most of these questions were beyond my use experience. }\end{array}$ \\
\hline Theme: Thanks $(n=3)$ \\
\hline Thanks for all your good work on the GAP program! \\
\hline Thank you for your efforts. \\
\hline Thank you for all you do! \\
\hline Theme: More useful data available $(n=2)$ \\
\hline $\begin{array}{l}\text { GAP is good for regional or cross-border analysis but anything limited to states or smaller generally has better data } \\
\text { sources available }\end{array}$ \\
\hline $\begin{array}{l}\text { GAP has largely become irrelevant to me in recent years as new alternative products have become available. I am in } \\
\text { a portion of the country that has not gotten a sorely needed regional Re-GAP, so we've had to make do pursuing } \\
\text { alternatives. }\end{array}$ \\
\hline No theme: \\
\hline $\begin{array}{l}\text { I am using GAP data for my dissertation research project about how local land use / land cover changes impacts the } \\
\text { local climate and meteorological events. Land Covers classes from GAP do not match simulation program LC } \\
\text { classes because GAP data has higher resolution, is more specific and detailed about local species but is useful } \\
\text { enough for analysis. }\end{array}$ \\
\hline $\begin{array}{l}\text { The multiscale nature of biodiversity conservation requires interoperable multiscale products, GAP does not } \\
\text { provide this. Many errors that managers find in GAP data are attributable to the scale at which the data are derived } \\
\text { for (national - regional). People want to use GAP data for policy decisions that need higher resolution data so they } \\
\text { become frustrated with GAP and it gets an undeservedly bad reputation. }\end{array}$ \\
\hline $\begin{array}{l}\text { Sure, please call me for a follow up[personal information deleted] Overall, I would like to see GAP program more } \\
\text { based on real science. The Landfire product was a plain disaster, as far as I can tell. How come? }\end{array}$ \\
\hline $\begin{array}{l}\text { I find that people I work with often think the GAP program is no longer active. I do not hear GAP data mentioned } \\
\text { in discussions at the LCC or JV/habitat partnership level. SWAP revisions are upon us, and many states have not } \\
\text { incorporated GAP into their plans to the level that could be achieved (variety of reasons). So much opportunity but } \\
\text { definitely a challange for GAP to re-establish itself especially in the East. }\end{array}$ \\
\hline $\begin{array}{l}\text { I cannot recall hearing a single popular or scientific article citing GAP as a data source in the past } 5+\text { years. Given } \\
\text { the concerns over climate change, the GAP data set should be very relevant, yet it seems to have faded into the } \\
\text { background. The reason for this eludes me. }\end{array}$ \\
\hline $\begin{array}{l}\text { Again, as far as I know GAP never produced a credible land cover map of Texas. I am not familiar with the other } \\
\text { Texas products. }\end{array}$ \\
\hline $\begin{array}{l}\text { Management of wildlife is local not national. Many agencies that manage wildlife do not control the habitats on } \\
\text { which wildlife occurs (eg private lands, or lands managed by other agencies). GIS-based analyses using GAP } \\
\text { datasets may help provide acceptable maps, but the mindset or local governments and state agencies needs to } \\
\text { change. }\end{array}$ \\
\hline
\end{tabular}


At the close of the survey, respondents were asked to provide their email address if they wanted to receive notifications of new release of GAP data, products, and other information. Seventy-one respondents provided an email address.

\section{Nonresponse Survey}

Because the survey sample included individuals who were not Federal employees, the survey had to be submitted to the information collection request process overseen by the Office of Management and Budget (OMB). OMB requires that any survey with a response rate less than 80 percent must have a nonresponse bias survey. The survey of GAP data users had an adjusted response rate of 35 percent; therefore, a nonresponse survey was required. A nonresponse survey is a brief survey sent to individuals who had an opportunity to respond to a survey but chose not to do so. The purpose of a nonresponse survey is to provide information to determine if those who did not respond to a survey are different from those who did. The nonresponse survey was sent to all individuals with valid email addresses who had received the GAP survey but did not respond, and who had not previously actively declined to participate by requesting removal from the survey list. The nonresponse survey opened on January 11 , 2013, and closed on January 24, 2013.

The nonresponse survey was sent to 672 individuals. Two individuals had invalid email addresses. Five individuals requested to be removed from the survey sample, and two individuals were out of the office for the duration of the data-collection process. This left a potential sample size of 663 . One hundred ninety-six respondents answered the nonresponse survey questions. The adjusted response rate was 30 percent.

The questions included in the nonresponse survey were taken from the original survey. The questions included in the nonresponse survey and the frequency of responses provided are presented below.

NRQ1 (Survey Q1) Which statement best describes your use of GAP data? $(n=196)$

\begin{tabular}{|l|c|}
\hline Response & Percent \\
\hline $\begin{array}{l}\text { a. I am using GAP data (either state, regional, or national data) at the present time, or have used it within the } \\
\text { last five (5) years. (Respondents selecting this response were directed to NRQ3 next.) }\end{array}$ & $\mathbf{4 7}$ \\
\hline $\begin{array}{l}\text { b. I last used GAP data (either state, or regional) more than five (5) years ago. (Respondents selecting this response } \\
\text { were directed to NRQ2 next.) }\end{array}$ & 27 \\
\hline $\begin{array}{l}\text { c. I am familiar with GAP data but have not used it. (Respondents selecting this response were directed to NRQ2 } \\
\text { next.) }\end{array}$ & 23 \\
\hline $\begin{array}{l}\text { d. I am not familiar with GAP and believe I have received this survey in error. (Respondents selecting this response } \\
\text { were directed to NRQ3 next.) }\end{array}$ & 3 \\
\hline
\end{tabular}

NRQ2 (Survey Q2) Which of the following is the most significant reason that you do not currently use GAP data? $(n=92)$

\begin{tabular}{|l|c|}
\hline Response & Percent \\
\hline a. GAP data are not available for my area. & 3 \\
\hline b. GAP data are not applicable to the work l'm currently doing. & $\mathbf{5 3}$ \\
\hline c. GAP data are outdated. & 8 \\
\hline d. I have concerns about the content of the land-cover data. & \\
\hline e. I have concerns about the quality of the land-cover data. & 10 \\
\hline f. I have concerns about the content of the predicted species distribution data. & \\
\hline
\end{tabular}




\begin{tabular}{|l|c|}
\hline g. I have concerns about the quality of the predicted species distribution data. & \\
\hline h. I have concerns about the content of the stewardship/protected areas data. & \\
\hline i. I have concerns about the quality of the stewardship/protected areas data. & 1 \\
\hline j. GAP data are not compatible with the hardware that I use. & \\
\hline k. GAP data are not compatible with the other software packages I use. & 7 \\
\hline I. Lack of information on how to use GAP data. & 7 \\
\hline m. Lack of support from my organization for use of GAP data. & 12 \\
\hline n. I use data similar to GAP data but that is provided by a different source. & \\
\hline
\end{tabular}

NRQ3 (Survey Q13) Which category best describes your organization? $(n=191)$

\begin{tabular}{|l|c|}
\hline Response & Percent \\
\hline a. Private (for profit) & 8 \\
\hline b. State & 17 \\
\hline c. University & 28 \\
\hline d. County & 2 \\
\hline e. Municipal & 2 \\
\hline f. Federal & $\mathbf{3 2}$ \\
\hline g. Non-profit & 9 \\
\hline h. Regional & \\
\hline i. Tribal & 2 \\
\hline j. Other: [open-ended response] & \\
\hline \multicolumn{1}{|c|}{ Retired } & \\
\hline Recently retired Fed. & \\
\hline Provincial & \\
\hline Conservation partnership & \\
\hline
\end{tabular}

NRQ4 (Survey Q15) Which field most closely describes your current position? ( $\mathbf{n = 1 9 2 )}$
\begin{tabular}{|l|c|}
\hline Response & Percent \\
\hline a. Ecology & $\mathbf{2 7}$ \\
\hline b. Biology & 4 \\
\hline c. Conservation & 15 \\
\hline d. GIS & 18 \\
\hline e. Land Use Planning & 3 \\
\hline f. Fish and Wildlife Management & 16 \\
\hline g. Land Management & 4 \\
\hline h Other: [open-ended response] $(n=24)$ & 13 \\
\hline Theme: Land-cover change $(n=2)$ & \\
\hline Land Cover Change Analysis & \\
\hline Land cover change + agriculture & \\
\hline Theme: IT $(n=2)$ & \\
\hline IT Management & \\
\hline IT & \\
\hline Theme: Education $(n=2)$ & \\
\hline Education $(2)$ & \\
\hline No theme: & \\
\hline
\end{tabular}




\begin{tabular}{|l|l|}
\hline Web programming (PHP/MySQL) & \\
\hline Water quality monitoring & \\
\hline University forest inventory research & \\
\hline Technology Transfer & \\
\hline Science Management & \\
\hline Research & \\
\hline Remote Sensing & \\
\hline Regional Digital Library & \\
\hline Program Coordination & \\
\hline Geospatial analysis for wildland fire ecology and management & \\
\hline Geomorphology & \\
\hline Forestry & \\
\hline Fish \& Wildlife Biologist, GIS Program & \\
\hline Federal Data Management & \\
\hline Environmental Project Management & \\
\hline Environmental Emergency Response & \\
\hline Engineering & \\
\hline Earth system sciences & \\
\hline Data management & \\
\hline
\end{tabular}

NRQ5 (Survey Q23) With which geographic set of data are you most experienced or familiar? ( $n=192)$

\begin{tabular}{|c|c|c|c|}
\hline \multicolumn{3}{|l|}{ Response } & \multirow{2}{*}{\begin{tabular}{|c|} 
Percent \\
$\mathbf{6 3}$
\end{tabular}} \\
\hline a. State: & & & \\
\hline \multicolumn{3}{|c|}{ Please select the state or U.S. territory for the GAP dataset with which you are most familiar: $(n=119)$} & \\
\hline Minnesota & 14 & $12 \%$ & \\
\hline Florida & 5 & $4 \%$ & \\
\hline New York & 5 & $4 \%$ & \\
\hline Washington & 5 & $4 \%$ & \\
\hline Wyoming & 5 & $4 \%$ & \\
\hline Arizona & 4 & $3 \%$ & \\
\hline California & 4 & $3 \%$ & \\
\hline Colorado & 4 & $3 \%$ & \\
\hline Kentucky & 4 & $3 \%$ & \\
\hline New Mexico & 4 & $3 \%$ & \\
\hline Oregon & 4 & $3 \%$ & \\
\hline Alaska & 3 & $3 \%$ & \\
\hline Georgia & 3 & $3 \%$ & \\
\hline lowa & 3 & $3 \%$ & \\
\hline Maine & 3 & $3 \%$ & \\
\hline Nebraska & 3 & $3 \%$ & \\
\hline North Carolina & 3 & $3 \%$ & \\
\hline Puerto Rico & 3 & $3 \%$ & \\
\hline Utah & 3 & $3 \%$ & \\
\hline Virginia & 3 & $3 \%$ & \\
\hline Wisconsin & 3 & $3 \%$ & \\
\hline
\end{tabular}




\begin{tabular}{|lll|l|}
\hline Delaware & 2 & $2 \%$ & \\
\hline Hawaii & 2 & $2 \%$ & \\
\hline Idaho & 2 & $2 \%$ & \\
\hline Kansas & 2 & $2 \%$ & \\
\hline Michigan & 2 & $2 \%$ & \\
\hline Mississippi & 2 & $2 \%$ & \\
\hline Montana & 2 & $2 \%$ & \\
\hline Nevada & 2 & $2 \%$ & \\
\hline North Dakota & 2 & $2 \%$ & \\
\hline Ohio & 2 & $2 \%$ & \\
\hline Oklahoma & 2 & $2 \%$ & \\
\hline Pennsylvania & 2 & $2 \%$ & \\
\hline South Carolina & 2 & $2 \%$ & \\
\hline Alabama & 1 & $1 \%$ & \\
\hline Indiana & 1 & $1 \%$ & \\
\hline New Jersey & 1 & $1 \%$ & \\
\hline Vermont & 1 & $1 \%$ & \\
\hline West Virginia & 1 & $1 \%$ & \\
\hline b. Regional: & & \\
\hline Please select the regional GAP dataset with which you are most familiar: $(n=47)$ & \\
\hline Northwest & 17 & $36 \%$ & \\
\hline Southeast & 17 & $36 \%$ & \\
\hline Southwest & 13 & $28 \%$ \\
\hline c. National: & & \\
\hline
\end{tabular}

\section{NRQ6 (Survey Q33) With which type of GAP data are you most experienced or familiar? $(n=187)$}

\begin{tabular}{|l|c|}
\hline Response & Percent \\
\hline a. Land cover & $\mathbf{5 6}$ \\
\hline b. Predicted Species Distributions & 21 \\
\hline c. Stewardship/protected areas & 5 \\
\hline d. Analysis (Land cover + Predicted Species Distribution + Stewardship/protected areas) & 17 \\
\hline
\end{tabular}

NRQ7 (Survey Q209) End question: Would you like to provide any other comments about the data provided by the Gap Analysis Program? [open-ended response] $(n=80)$ Response

Theme: General positive comment $(n=12)$

GAP landcover data has been invaluable to our work - particularly because it now provides relatively seamless coverage across state lines. This allows us to export tools developed for conservation in one state to other areas of the country.

When I was using GAP data, I was happy with it. The Land cover dataset was incredibly useful for deriving all kinds of other info.

Valuable data and very important to continue to collect and provide access to the public. I'm unfamiliar with the data quality and thus reluctant to use for county level analysis

Used MN GAP in many projects, it's an important data source

The data are extremely useful for a variety of analysis and serve as starting points for generating hypotheses that drive further research.

Keep up the good work. 


\begin{tabular}{|c|}
\hline It's a great resource! \\
\hline I think the newer GAP data is a great improvement over the first version. \\
\hline $\begin{array}{l}\text { I retired in } 2003 \text { after } 25 \text { years as a Biology Professor. The GAP data at the State and Regional levels before then } \\
\text { was very helpful in understanding distribution of the fungi I was researching. }\end{array}$ \\
\hline $\begin{array}{l}\text { I have been very impressed with the Gap Analysis Program and the land cover data that I've used in the past. } \\
\text { Because my work tends to be focused on wildland fire rather than conservation, I generally use LANDFIRE data... } \\
\text { but that doesn't mean I think it's necessarily better than GAP. I do use the GAP protected areas database (PAD v1.1) } \\
\text { for land ownership information nationally, and for the most part I think it's great. }\end{array}$ \\
\hline $\begin{array}{l}\text { I found the GAP data to be very useful in my previous job, as a consultant calculating the Ecological Footprint of } \\
\text { Utah. We needed land cover data for the renewable biocapacity calculations. See our final report, if you like, at } \\
\text { http://www.utahpop.org/vitalsigns/research/report_2007.htm. Thank you! }\end{array}$ \\
\hline Great stuff! Very useful for academic and conservation purposes! \\
\hline Theme: Respondent's background or perspective $(n=9)$ \\
\hline $\begin{array}{l}\text { Perhaps improvements and updates have been made in GAP data of which I am not aware, and I might use it or } \\
\text { develop projects that would involve use of the GAP data if I were more familiar with current products. }\end{array}$ \\
\hline Not applicable to my program. Others in FWS use it \\
\hline I retired 5 years ago and have little use for Gap data now. \\
\hline I really know very little about this \\
\hline I asked one of my staff who were more involved in the use of the GAP data to respond to your survey \\
\hline I am not familiar with GAP data. \\
\hline I am not familiar with gap analysis \\
\hline I am "using them" only in that I am collaborating with another researcher that is using MNGAP data. \\
\hline $\begin{array}{l}\text { As the programs evolved, I became more involved with NBII than GAP per se, but continue to use both GAP- } \\
\text { derived data and the central concepts of the GAP program in research, teaching, and graduate education. }\end{array}$ \\
\hline Theme: Update needed $(n=8)$ \\
\hline Would like to see updated species distribution maps every five years or so with new data \\
\hline Very desperately needs a higher resolution redo for Hawai'i. \\
\hline The program is invaluable. I hope funding continues so that the data can be periodically updated and/or improved. \\
\hline $\begin{array}{l}\text { Really like the Southeast GAP product, just wish it could be updated more frequently. This is a seminal data set for } \\
\text { our analyses! }\end{array}$ \\
\hline $\begin{array}{l}\text { Need updates with more current land cover and more sophisticated species modeling given new technologies } \\
\text { available. }\end{array}$ \\
\hline $\begin{array}{l}\text { My organization provided all the occurrence records used by GAP. More up to date land cover datasets would be } \\
\text { very useful }\end{array}$ \\
\hline $\begin{array}{l}\text { Land cover data need to be updated thru time, as significant landscape change has been occurring in the Southwest } \\
\text { over the last } 12+\text { years. }\end{array}$ \\
\hline $\begin{array}{l}\text { Best land cover data I've worked with still, at least for the forested portion of the state. Need detailed cover down to } \\
\text { tree species for much of my work. Would like to see updates to the Landcover. May want to partner with NLCD to } \\
\text { capture what it seems to identify best, ag and development. }\end{array}$ \\
\hline Theme: No comment $(n=8)$ \\
\hline No (6) \\
\hline None \\
\hline $\mathrm{n} / \mathrm{a}$ \\
\hline Theme: Reason for not responding to earlier survey $(n=7)$ \\
\hline Very helpful to have. Thank you! Sorry, I didn't fill out one earlier--crazy busy lately. \\
\hline Sorry for not responding before. Been a very hectic year..... \\
\hline $\begin{array}{l}\text { Since I mainly use the data to help teachers answer questions about local wildife and may need additional assistance } \\
\text { from our GAP and GIS staff I didn't take the time to answer the previous survey. I do not work with our data base }\end{array}$ \\
\hline
\end{tabular}




\begin{tabular}{|c|}
\hline on a daily basis \\
\hline $\begin{array}{l}\text { My program was responsible for image and geospatial data processing and analysis for the NYS Gap Analysis } \\
\text { Project. I am very familiar with GAP and the geospatial database. I thought I responded to your earlier survey. I } \\
\text { apologize for not doing so. Great program but users seem to prefer NLDC land cover products rather than GAP land } \\
\text { cover products. I don't have much experience with species distribution modeling products and how they are used in } \\
\text { the academic, public, or private sector. }\end{array}$ \\
\hline I am more of a GAP data developer than a GAP data user, which is why I did not respond to the original survey. \\
\hline I am a manager of staff who use Gap products; that is why I did not respond previously. \\
\hline $\begin{array}{l}\text { GAP data is essential to conservation efforts. I have used land cover data for years as well as the protected areas } \\
\text { database. I recently completed an update to PAD-US for Kentucky and was glad to have the opportunity to } \\
\text { contribute. My previous non-response was because I have left the state agency where these emails were sent and } \\
\text { believed another member of the data management team filled out the survey. I am not with a land trust and will } \\
\text { subscribe under that email. }\end{array}$ \\
\hline Theme: Reason for using alternate data $(n=5)$ \\
\hline $\begin{array}{l}\text { The GAP data served our needs at the time we used it to map land cover over a } 3.3 \text { million acre land base. } \\
\text { However, we only used it once and adopted other datasets which I believe were trained or based in part on GAP } \\
\text { data for LANDFIRE. }\end{array}$ \\
\hline $\begin{array}{l}\text { The Gap analysis was used for a document/program that assisted in developing County's comprehensive policies } \\
\text { and goals. However, it was not integrated into the regulatory framework, therefore the data is not used widely by } \\
\text { staff in permitting and review assessments. }\end{array}$ \\
\hline $\begin{array}{l}\text { In recent years my work and the work of my students has had a focus of larger geographic scale (smaller area at } \\
\text { more detail) so we have used NAIP imagery for current land cover information for our models. GAP is excellent } \\
\text { data for more broad studies, and especially useful if it includes both current and historical layers. }\end{array}$ \\
\hline I think it's great data, it just doesn't fit my current research. \\
\hline $\begin{array}{l}\text { I believe GAP land cover is a great dataset, however, the thematic classes generated by GAP do not meet my } \\
\text { research requirements. }\end{array}$ \\
\hline Theme: What would be helpful $(n=4)$ \\
\hline $\begin{array}{l}\text { We use the national GAP stewardship classification as a guide to categorize local land stewardship. We } \\
\text { occasionally refer to SWReGAP data, as well as other national, state and regional land cover data. There should be } \\
\text { a national process for gathering information from local land management agencies about changes in stewardship; or } \\
\text { if there is one, I'd like to know about it. }\end{array}$ \\
\hline Regional, not statewide, GAP products would be most useful. \\
\hline $\begin{array}{l}\text { Please develop a program to provide national land cover data every } 5 \text { years. GAP land cover is the most important } \\
\text { data because it is used by the most people. States and other groups are now creating land cover data because GAP } \\
\text { stopped, and those other data are often not consistent in classification schemes and methods. Relying on states and } \\
\text { other groups to figure out how to provide regional maps is far less effective and less efficient than if GAP was } \\
\text { providing this service nationally. }\end{array}$ \\
\hline $\begin{array}{l}\text { Desktop tools to display GAP data are needed. Use of GAP data must not require advanced GIS skills, must be user } \\
\text { friendly. Periodic updates (e.g., quarterly) on what GAP data are available. Provide examples of how GAP data are } \\
\text { being used in natural resource management. }\end{array}$ \\
\hline Theme: Comments about errors in or accuracy of data $(n=4)$ \\
\hline $\begin{array}{l}\text { The data provided by Iowa's GAP was the first comprehensive look at species distribution for almost all of Iowa's } \\
\text { terrestrial vertebrate species. For many species, the data points used to determine distribution were often not } \\
\text { current, but the information still allowed an informed interpretation of where each particular species might still be } \\
\text { found. Based on my } 35 \text { years experience in the field, it seems the predicted range for most species was very } \\
\text { accurate. }\end{array}$ \\
\hline $\begin{array}{l}\text { I think GAP is invaluable data! I appreciate that we continue to update it and improve its accuracy. I'm hoping that } \\
\text { we continue to work on the land cover data (i.e., improve Columbia Basin shrub-steppe). }\end{array}$ \\
\hline $\begin{array}{l}\text { I have used gap for Burned Area Emergency Response (BAER) assessments in Nevada, California, New Mexico, } \\
\text { and Utah. I have found that it is many times inaccurate and I have had to tweek data in our BAER reports to reflect } \\
\text { what is actually on the ground. CA gap sucks }\end{array}$ \\
\hline
\end{tabular}




\begin{tabular}{|c|}
\hline $\begin{array}{l}\text { Gap data is in the foundation of the LANDFIRE program. I look forward to the day when these various data and } \\
\text { the derivations are dependable. I really appreciate having national wall-to-wall data for regional analysis projects. } \\
\text { Thank you for your foresight. }\end{array}$ \\
\hline Theme: Outreach/cooperation $(n=3)$ \\
\hline $\begin{array}{l}\text { For federal folks, collaboration on Land Cover between GAP and LANDFIRE would be most beneficial. } \\
\text { LANDFIRE is our default source for fire related analysis but GAP input could likely improve the land cover, } \\
\text { especially in the Southeast United States. }\end{array}$ \\
\hline $\begin{array}{l}\text { The greatest utility of the GAP data is now being made through a joint USGS/EPA effort to create a national level } \\
\text { product entitled the Enviro Atlas. The GAP deductive models have been grouped into functional groups that } \\
\text { represent ecosystem services. The first national deployment of the Atlas is scheduled in September 2013. This effort } \\
\text { will significantly elevate the prominence of the GAP models, and subsequently the GAP Program. I suggest you } \\
\text { contact Kevin Gergely or Alexa McKerrow to learn more. Collectively, the joint agency effort will be a game } \\
\text { changer. }\end{array}$ \\
\hline $\begin{array}{l}\text { The data is extremely useful. However, I don't see it marketed as much as I would like, and having easy online } \\
\text { query tools could greatly enhance it's use. E.g. there is enough data there to provide any user at any location a } \\
\text { habitat typing and a list of vertebrate species likely to be found. Why not partner with Google or the mobile } \\
\text { application market to really get this data out there and in the hands of not just land managers, but the general } \\
\text { public? }\end{array}$ \\
\hline Theme: More useful data available $(n=3)$ \\
\hline $\begin{array}{l}\text { I did not know the GAP program was still active. With greater local data and GIS software availability I have been } \\
\text { relying upon GAP like analyses on our land system using local data and ESRI's ArcGIS. }\end{array}$ \\
\hline $\begin{array}{l}\text { Florida has relatively high-precision, high quality land cover data in the Cooperative Land Cover (CLC) dataset } \\
\text { maintained by Florida Natural Areas Inventory with collaboration by Florida Fish \& Wildlife Conservation } \\
\text { Commission. }\end{array}$ \\
\hline $\begin{array}{l}\text { Florida has other higher quality land cover and species distribution information that are the standards for } \\
\text { conservation use in the state }\end{array}$ \\
\hline Theme: Negative comment regarding land-cover data $(n=3)$ \\
\hline $\begin{array}{l}\text { The Gap program data is too coarse in its categories of land cover and because of that and inherent low resolution } \\
\text { lacks the precision to be truly useful in operational forest or wildlife management...and related research. }\end{array}$ \\
\hline $\begin{array}{l}\text { The consensus is that the GAP land cover produced for Ohio was a complete and total failure, with millions of } \\
\text { dollars wasted. }\end{array}$ \\
\hline I have struggled with various land cover maps none of which seem to have data at the resolution that I need. \\
\hline Theme: Aquatic data $(n=3)$ \\
\hline $\begin{array}{l}\text { My impression from exposure to the Iowa aquatic GAP analysis products is that the predictor variables were quite } \\
\text { generalized and did not inspire a lot of confidence in the model's ability to predict fish species occurrence. The data } \\
\text { used to develop the models is now outdated, in the sense that it does not include fish survey data from the past } 10 \\
\text { years or so. }\end{array}$ \\
\hline $\begin{array}{l}\text { Initially the NY Aquatic Gap program of USGS Cortland had been promoted as a capability that biologists could } \\
\text { use in their office. In NY that hasn't happened, but the program supervisor has extracted data and made it available } \\
\text { in a project last year. That is my limit of direct, personal involvement. }\end{array}$ \\
\hline I am most interested in aquatic species information. I'd like to see more modeling and datasets for aquatic systems. \\
\hline Theme: Comment about the survey $(n=3)$ \\
\hline $\begin{array}{l}\text { I stated earlier that I do not use GAP data but could not complete the survey unless I gave some response as to use } \\
\text { and familiarity of the data. These should have been blank for me - I was involved in GAP in a variety of ways - but } \\
\text { never a user. The data seem to over [sic] wonderful potential - I would like to see the three components continue as } \\
\text { they provide a comprehensive view of conservation in the US. }\end{array}$ \\
\hline $\begin{array}{l}\text { As a high level administrator I don't deal directly with GAP data anymore, my staff does. Your survey doesn't allow } \\
\text { me to answer in context with my position versus the usefulness of the information to the agency. }\end{array}$ \\
\hline $\begin{array}{l}\text { I did not complete this survey because I am the office director/administrator and forwarded the survey to my data } \\
\text { manager who as I recall responded to the survey. I only know we have used GAP data in the past and assume we } \\
\text { still use it. I did not forward this email to my data manager because directions said not to. Seems you should have }\end{array}$ \\
\hline
\end{tabular}




\begin{tabular}{|c|}
\hline $\mathrm{n}$ about whether recipient is the right target/person. \\
\hline Theme: How GAP data were used $(n=2)$ \\
\hline I have used the landcover data for developing logistic regression models for species distribution in R and ArcGis. \\
\hline $\begin{array}{l}\text { I have used gap analysis and its data in a conceptual way in reports to two federal agencies - suggesting that they } \\
\text { need to use gap data in their analyses to prioritize future conservation areas. }\end{array}$ \\
\hline No theme: \\
\hline $\begin{array}{l}\text { In Maine, the most significant problem was that the actual data was not available; there were summary reports. The } \\
\text { actual data was to be published prior and the timeframe was unworkable for on the ground conservation planning } \\
\text { and implementation needs of our agency. We were able to access GAP gis data for use in other States. }\end{array}$ \\
\hline $\begin{array}{l}\text { Up-to-date land cover data is still an important need for our state, however given the age of the GAP project data in } \\
\text { our state (MN) the usefulness of GAP for this purpose is limited. The species distribution data has been of limited } \\
\text { use as far as I can tell, for MN. The Stewardship component is poor, and was out of date before it was even } \\
\text { published. In MN the GAP project was essentially seen as a means to get a Land Cover dataset by the DNR } \\
\text { Forestry division. Our DNR Natural Heritage Program and our County Biological Survey Programs and Wildlife } \\
\text { Programs were already mature and not interested in the data produced from the GAP process. They were already } \\
\text { taking a much more detailed approach. Now the MN GAP data is over } 15 \text { years old and of little use except for time- } \\
\text { change analysis. NLCD has become the Land Cover dataset of record, and the DNR is in the process of completing } \\
\text { and consolidating its native plant community inventory GIS. }\end{array}$ \\
\hline $\begin{array}{l}\text { The stewardship layer has been the most useful layer long term. Landcover was used extensively until other current } \\
\text { datasets replaced it. PSD was the most marginal dataset for usefulness }\end{array}$ \\
\hline $\begin{array}{l}\text { The Predicted Species Distributions was too general to be very useful for anything but very general planning. } \\
\text { Stewardship/protected areas was so out-of-date it was not useful. BLM had much better data. }\end{array}$ \\
\hline Just waiting for ReGAP \\
\hline $\begin{array}{l}\text { It's too coarse to be useful for most of our applications, so we rarely use it, although as a last resort it's better than } \\
\text { nothing. }\end{array}$ \\
\hline
\end{tabular}

At the close of the nonresponse survey, respondents were asked to provide an email address if they wanted to receive notifications of new release of GAP data, products, and other information. Sixtyone respondents provided an email address.

\section{Limitations to Report}

This report to respondents provides a preliminary summary of the results of the survey regarding the use of GAP data. Although the frequencies of responses and the average response for the questions are useful information, these summary statistics do not constitute complete analyses of the survey data.

\section{Acknowlegments}

This study was requested and funded by the Gap Analysis Program of the USGS. We appreciate the opportunity to conduct this research. We thank the individuals who took the time to respond to our survey. Two reviewers provided helpful feedback on a draft of this report: we thank Dr. Clifford Duke, Director of Science Programs at the Ecological Society of America, and Dr. Mary Barber, Senior Research Environmental Scientist at RTI International.

\section{Reference Cited}

Ratz, J.M., and Conk, S.J., 2014, Review and bibliometric analysis of published literature citing data produced by the Gap Analysis Program (GAP): U.S. Geological Survey Open-File Report 2013-1294, 117 p., http://dx.doi.org/10.3133/ofr20131294. 